\title{
Evaluation of National Atmospheric Deposition Program Measurements for Colocated Sites CO89 and C098 at Rocky Mountain National Park, Water Years 2010-14
}

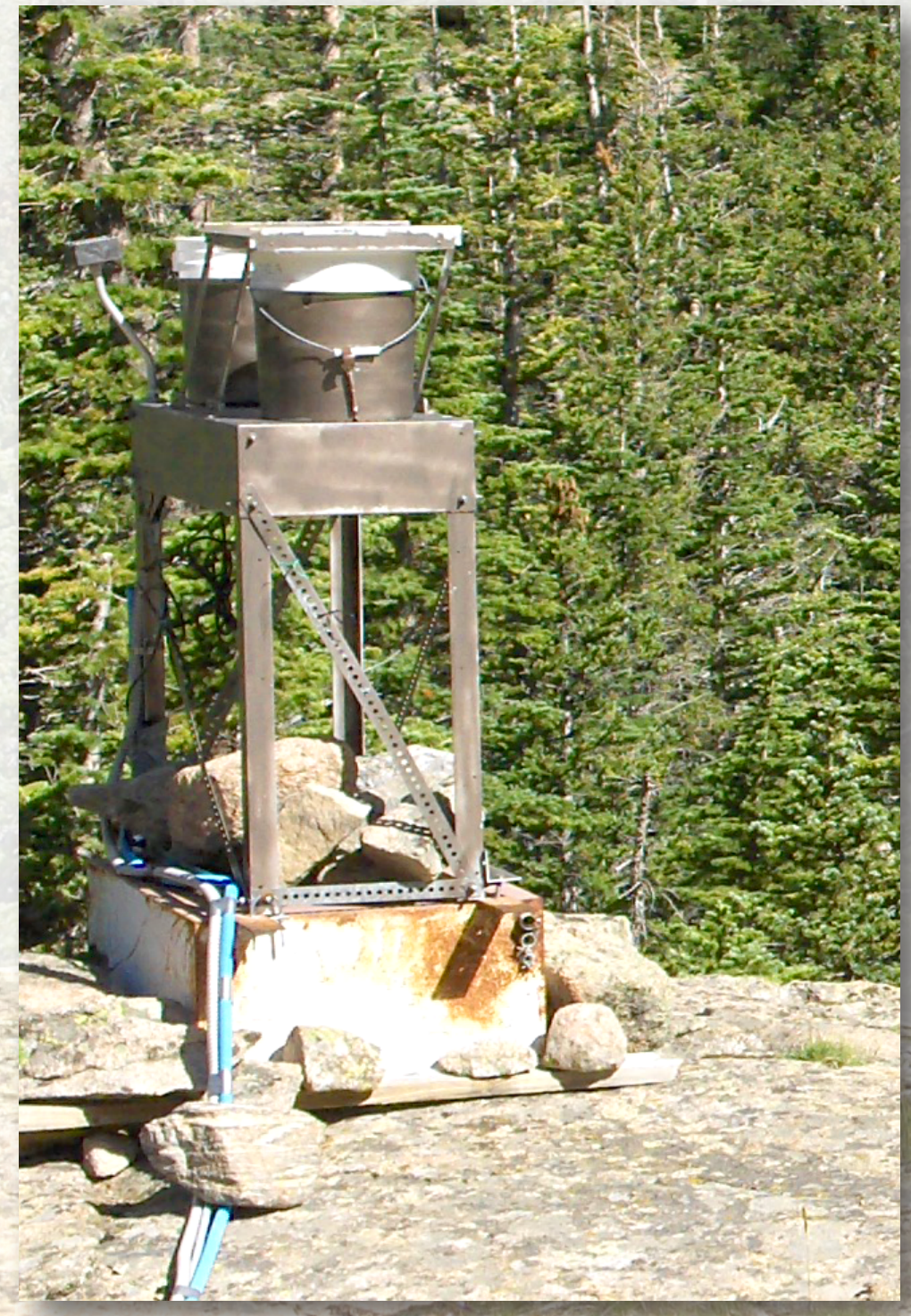

Scientific Investigations Report 2016-5051

U.S. Department of the Interior

U.S. Geological Survey

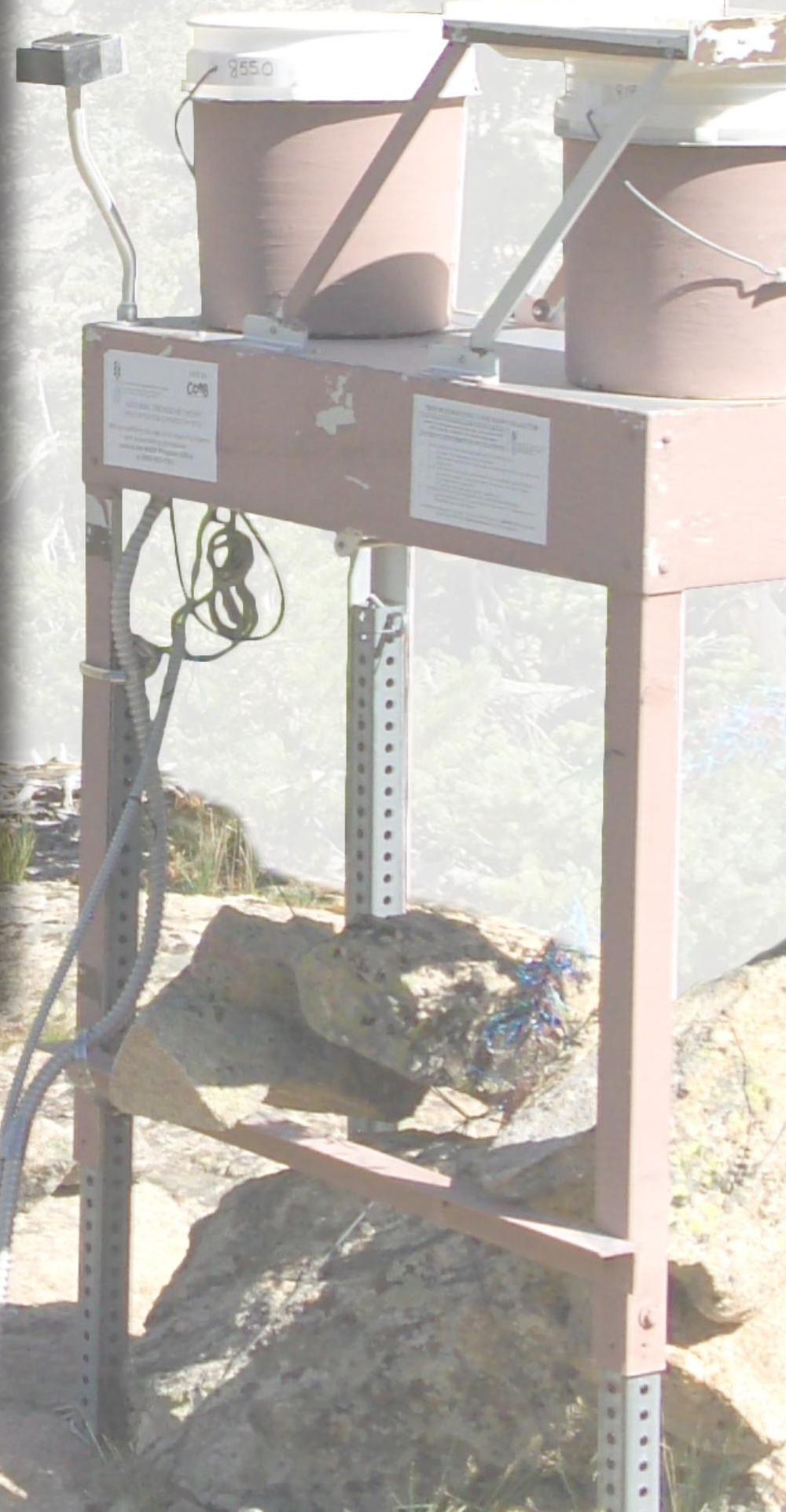


Cover. Automatic precipitation collectors for National Atmospheric Deposition Program, National Trends Network sites C089 and C098 at Loch Vale, Rocky Mountain National Park, Colorado. 


\section{Evaluation of National Atmospheric Deposition Program Measurements for Colocated Sites CO89 and C098 at Rocky Mountain National Park, Water Years 2010-14}

By Gregory A. Wetherbee

Scientific Investigations Report 2016-5051 


\title{
U.S. Department of the Interior SALLY JEWELL, Secretary
}

\section{U.S. Geological Survey Suzette M. Kimball, Director}

\author{
U.S. Geological Survey, Reston, Virginia: 2016
}

For more information on the USGS - the Federal source for science about the Earth, its natural and living resources, natural hazards, and the environment—visit http://www.usgs.gov or call 1-888-ASK-USGS.

For an overview of USGS information products, including maps, imagery, and publications, visit http://store.usgs.gov.

Any use of trade, firm, or product names is for descriptive purposes only and does not imply endorsement by the U.S. Government.

Although this information product, for the most part, is in the public domain, it also may contain copyrighted materials as noted in the text. Permission to reproduce copyrighted items must be secured from the copyright owner.

Suggested citation:

Wetherbee, G.A., 2016, Evaluation of National Atmospheric Deposition Program measurements for colocated sites C089 and C098 at Rocky Mountain National Park, water years 2010-14: U.S. Geological Survey Scientific Investigations Report 2016-5051, 32 p., http://dx.doi.org/10.3133/sir20165051.

ISSN 2328-0328 (online) 


\section{Contents}

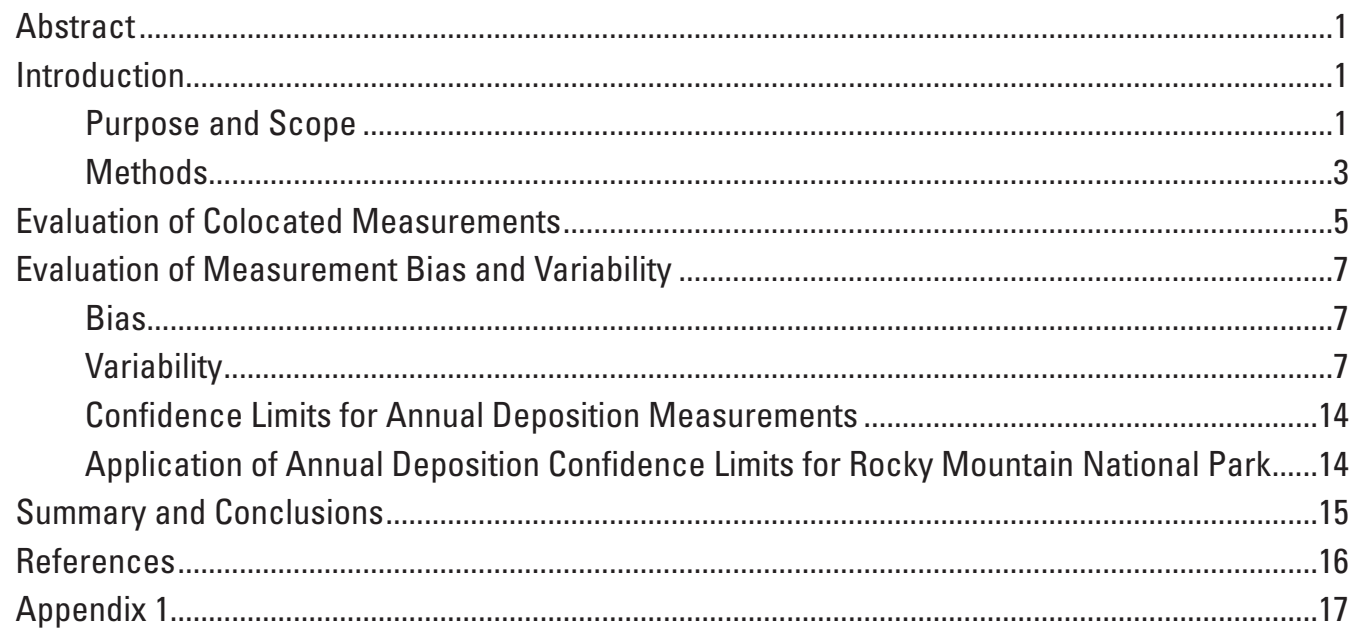

\section{Figures}

1. Colocated National Atmospheric Deposition Program/National Trends Network precipitation collectors and rain gages at sites CO89 and CO98 at Loch Vale, Rocky Mountain National Park, Colorado ....

2. Frequency of samples with $A, B$, and C Quality Rating codes for National Atmospheric Deposition Program/National Trends Network weekly samples collected at colocated sites CO89 and CO98, Loch Vale, Rocky Mountain National Park, water years 2010-14

3. Weekly precipitation-depth, sample-volume, and inorganic nitrogen concentration absolute percent differences by precipitation type for colocated National Atmospheric Deposition Program/National Trends Network sites C098 and C089, water years 2010-14.

4. Weekly relative precipitation-depth and sample-volume (C098 minus C089) differences for colocated National Atmospheric Deposition Program/National Trends Network sites CO98 and C089, water years 2010-14

5. Weekly relative ammonium, nitrate, and inorganic nitrogen concentration (C098 minus C089) differences for colocated National Atmospheric Deposition Program/National Trends Network sites C098 and C089, water years 2010-14. 


\section{Tables}

1. Wet-deposition sample types collected at National Atmospheric Deposition Program/National Trends Network sites CO89 and C098, Loch Vale, Rocky Mountain National Park, water years 2010-14.

2. Precipitation depths measured with wet-deposition samples for colocated sites CO89 and C098, Loch Vale, Rocky Mountain National Park, calendar years 2010-14

3. Weekly colocated sampler concentration differences and results of Wilcoxon signed rank test for valid paired samples collected at National Atmospheric Deposition Program (NADP)/National Trends Network sites C089 and C098, water years 2010-14, and comparison to results from previous studies at other NADP sites from across the United States, water years 1989-2001

4. Kruskal-Wallis test values for differences among water years 2010-14 for weekly National Atmospheric Deposition Program/National Trends Network sites C089 and $\mathrm{CO98}$

5. Water-year precipitation-weighted mean concentrations and total deposition values for National Atmospheric Deposition Program/National Trends Network sites C089 and C098, water years 2010-14.

6. Annual inorganic nitrogen deposition measured at National Atmospheric Deposition Program sites CO89 and C098, Loch Vale, Rocky Mountain National Park, water years 2010-14

7. Calculated confidence limits for inorganic nitrogen deposition measurements at National Atmospheric Deposition Program site C098, Loch Vale, Rocky Mountain National Park, water years 2010-14

1-1. Wet-deposition sample analysis data for colocated sites C089 and C098, water years 2010-14 


\section{Conversion Factors}

International System of Units to U.S. customary units

\begin{tabular}{|c|c|c|}
\hline Multiply & By & To obtain \\
\hline \multicolumn{3}{|c|}{ Length } \\
\hline millimeter (mm) & 0.03937 & inch (in.) \\
\hline centimeter $(\mathrm{cm})$ & 0.3937 & inch (in.) \\
\hline meter $(\mathrm{m})$ & 3.281 & foot $(\mathrm{ft})$ \\
\hline kilometer (km) & 0.6214 & mile (mi) \\
\hline \multicolumn{3}{|c|}{ Area } \\
\hline square meter $\left(\mathrm{m}^{2}\right)$ & 0.0002471 & acre \\
\hline hectare (ha) & 2.471 & acre \\
\hline \multicolumn{3}{|c|}{ Volume } \\
\hline milliliter (mL) & 0.034 & ounce, liquid (oz) \\
\hline $\operatorname{liter}(\mathrm{L})$ & 1.057 & quart (qt) \\
\hline \multicolumn{3}{|c|}{ Mass } \\
\hline milligram (mg) & $3.527 \times 10^{-5}$ & ounce, avoirdupois (oz) \\
\hline $\operatorname{gram}(\mathrm{g})$ & 0.03527 & ounce, avoirdupois (oz) \\
\hline kilogram (kg) & 2.205 & pound avoirdupois (lb) \\
\hline \multicolumn{3}{|c|}{ Load } \\
\hline kilogram per hectare $(\mathrm{kg} / \mathrm{ha})$ & 0.892 & pound per acre (lb/acre) \\
\hline
\end{tabular}

\section{Datum}

Vertical coordinate information is referenced to the North American Vertical Datum of 1988 (NAVD 88).

Horizontal coordinate information is referenced to the North American Datum of 1983 (NAD 83).

\section{Supplemental Information}

Water year is the 12-month period from October 1 through September 30 of the following year and is designated by the calendar year in which it ends. 


\section{Abbreviations}

\begin{tabular}{|c|c|}
\hline Avg & average \\
\hline CAL & Central Analytical Laboratory \\
\hline $\mathrm{cm}$ & centimeters \\
\hline $\mathrm{kg} / \mathrm{ha}$ & kilograms per hectare \\
\hline $\mathrm{kg} \mathrm{N}_{\text {inorg }} / \mathrm{ha}$ & kilograms inorganic nitrogen per hectare \\
\hline m & meters \\
\hline $\mathrm{mg} / \mathrm{L}$ & milligrams per liter \\
\hline $\mathrm{mm}$ & millimeters \\
\hline $\mathrm{mL}$ & milliliters \\
\hline N & nitrogen \\
\hline NADP & National Atmospheric Deposition Program \\
\hline NDRP & Nitrogen Deposition Reduction Plan \\
\hline $\mathrm{NH}_{4}^{+}$ & ammonium \\
\hline $\mathrm{N}_{\text {inorg }}$ & inorganic nitrogen \\
\hline $\mathrm{NO}_{3}^{-}$ & nitrate \\
\hline NTN & National Trends Network \\
\hline ppt & precipitation \\
\hline PWMC & precipitation-weighted mean concentration \\
\hline QR & Quality Rating \\
\hline RSD & relative standard deviation \\
\hline SD & standard deviation \\
\hline USGS & U.S. Geological Survey \\
\hline
\end{tabular}




\title{
Evaluation of National Atmospheric Deposition Program Measurements for Colocated Sites C089 and C098 at Rocky Mountain National Park, Water Years 2010-14
}

\author{
By Gregory A. Wetherbee
}

\section{Abstract}

Atmospheric wet-deposition monitoring in Rocky Mountain National Park included precipitation depth and aqueous chemical measurements at colocated National Atmospheric Deposition Program/National Trends Network (NADP/NTN) sites CO89 and CO98 (Loch Vale) during water years 2010-14 (study period). The colocated sites were separated by approximately 6.5 meters horizontally and 0.5 meter in elevation, in accordance with NADP siting criteria. Assessment of the 5 -year record of colocated data is intended to inform management decisions pertaining to the achievement of nitrogen deposition reduction goals of the Rocky Mountain National Park Nitrogen Deposition Reduction Plan.

The data at site CO98 met NADP completeness criteria for the first time in 29 years of operation in 2011 and then again in 2012. During the study period, data at site CO89 met completeness criteria in 2012. Median weekly relative precipitation-depth differences between sites CO89 and CO98 ranged from 0 to 0.25 millimeter during the study period. Median weekly absolute percent differences in sample volume ranged from 5 to 10 percent. Median relative concentration differences for weekly ammonium $\left(\mathrm{NH}_{4}^{+}\right)$and nitrate $\left(\mathrm{NO}_{3}^{-}\right)$ concentrations were near the NADP Central Analytical Laboratory's method detection limits and thus were considered small. Absolute percent differences for water-year 2010-14 precipitation-weighted mean concentrations of $\mathrm{NH}_{4}^{+}, \mathrm{NO}_{3}^{-}$, and inorganic nitrogen $\left(\mathrm{N}_{\text {inorg }}\right.$ ) ranged from 0.0 to 25.7 percent. Absolute percent differences for water-year $2010-14 \mathrm{NH}_{4}^{+}$, $\mathrm{NO}_{3}^{-}$, and $\mathrm{N}_{\text {inorg }}$ deposition ranged from 2.1 to 18.9 percent, 3.3 to 24.5 percent, and 0.3 to 17.4 percent, respectively.

\section{Introduction}

Wet-deposition data were collected at National Atmospheric Deposition Program/National Trends Network (NADP/NTN) monitoring site CO89 from September 29, 2009, to September 30, 2014. The CO89 site was colocated with NADP/NTN site CO98 (installed in 1983 at approximately 3,159 meters [m] altitude, 40.2878 degrees north latitude,
105.6628 degrees west longitude, in the Loch Vale Watershed [Loch Vale] of Rocky Mountain National Park, Colorado). The last sample collected at site CO89 was on September 30, 2014, which was the day the collector was removed from the site.

Sites CO89 and CO98 included a rain gage to measure precipitation depth and a precipitation collector to capture samples for chemical analysis. The collectors were spaced approximately $6.2 \mathrm{~m}$ apart horizontally and within $0.5 \mathrm{~m}$ vertically. The rain gages were spaced approximately $6.5 \mathrm{~m}$ apart horizontally and within $0.5 \mathrm{~m}$ vertically, in compliance with NADP siting criteria (National Atmospheric Deposition Program, 2014).

Concentrations of chemical constituents in the weekly composite wet-deposition samples from the paired collectors were evaluated along with continuous precipitation-depth records from the paired rain gages. Comparison of monitoring records from the colocated equipment allowed variability in NADP measurements at the site to be assessed for these two sites during 2009-14. In addition, variability calculated for the CO89 and CO98 colocated site data was compared to variability calculated for other colocated sites in the NADP/NTN monitoring network from across the United States.

\section{Purpose and Scope}

This report presents an evaluation of wet-deposition data quality, including completeness, bias, and variability, based on data collected during water years 2010-14 (study period) at colocated NADP sites CO89 and CO98. Water years begin on October 1 and end on September 30 of the following year, and the latter determines the enumeration. Monitoring reports for the National Park Service (NPS) Nitrogen Deposition Reduction Plan (NDRP) (National Park Service, 2007) present results on a calendar year basis, but monitoring data for the CO89 site were collected for 5 complete water years, not complete calendar years (Morris and others, 2015). This overall assessment of data quality and variability is intended to inform natural resource management under the NDRP.

Analysis of NADP data variability for ammonium $\left(\mathrm{NH}_{4}^{+}\right)$, nitrate $\left(\mathrm{NO}_{3}^{-}\right)$, and inorganic nitrogen $\left(\mathrm{N}_{\text {inorg }}\right)$ concentration (chemical parameters) and sample volume and 

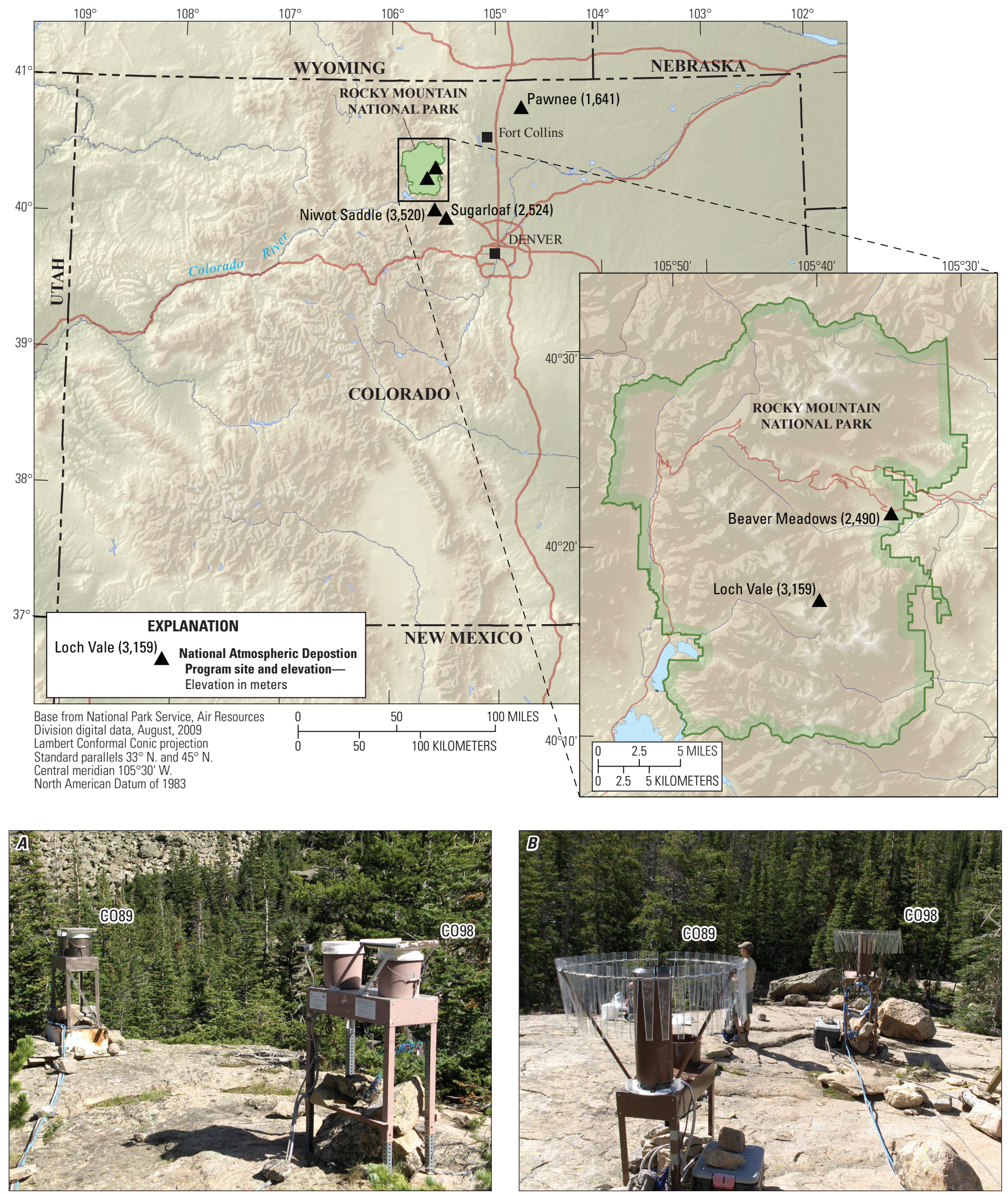

Figure 1. Location of the National Atmospheric Deposition Program (NADP) site for the Loch Vale Watershed and photographs of the colocated NADP/National Trends Network ( $A$ ) precipitation collectors and (B) rain gages at sites CO89 and C098 at Loch Vale, Rocky Mountain National Park, Colorado. Map modified from National Park Service (2011). 
precipitation depth (physical parameters) are included in this report. Chemical concentrations and sample volumes for weekly wet-deposition samples for water years 2010-14 were accessed at http://nadp.isws.illinois.edu/NTN/ntnData.aspx (National Atmospheric Deposition Program, 2016a), but 2014 data, although quality-assured and considered final by the Central Analytical Laboratory (CAL), were not available online in time for this report. Water-year 2014 results were obtained from Mark Rhodes (National Atmospheric Deposition Program Office, written commun., January 30, 2015), and those data were officially released in October 2015. Precipitation records for the study period, in 15-minute and daily increments, were accessed at http://nadp.sws.uiuc.edu/siteOps/ ppt/default.aspx on January 19, 2016 (National Atmospheric Deposition Program, 2016b). The NADP calculated weekly precipitation amounts from the 15-minute rain gage records using sample start and end times recorded by the site operators for CO89 and CO98. Variability and bias were evaluated on a weekly and annual (water year) basis. Precipitation-weighted mean concentrations and annual deposition values calculated on a water-year basis by NADP were obtained from the NADP Web site on January 11, 2016 (National Atmospheric Deposition Program, 2016a).

Quantification of data variability is important for interpretation of monitoring data with respect to the glidepath approach prescribed by the NDRP. The glidepath represents a linear reduction of $\mathrm{N}_{\text {inorg }}$ wet deposition starting with 3.0 kilograms per hectare $(\mathrm{kg} / \mathrm{ha})$, measured in 2006 , and ending with the accepted critical load of $1.5 \mathrm{~kg} / \mathrm{ha}$ (Baron, 2006) projected for attainment in 2032. In late 2015, the NPS Air Resources Division requested that the U.S. Geological Survey (USGS) provide estimation and explanation of confidence limits for annual $\mathrm{N}_{\text {inorg }}$ deposition measurements using the colocated measurements from sites $\mathrm{CO} 89 / \mathrm{CO} 98$. This report concludes with a discussion of application of the results with respect to the NDRP glidepath goals for $\mathrm{N}_{\text {inorg }}$ wet deposition.

\section{Methods}

Field and laboratory procedures were identical for the CO89 and CO98 official NADP/NTN sites during the study period. All samples were analyzed by the CAL in Champaign, Illinois. Weekly composite sample-collection and quality-assurance methods were provided by Dossett and Bowersox (1999). Sample analysis methods are available on the CAL Web site at http:// nadp.sws.uiuc.edu/cal/summary_of_procedures.html (accessed February 23, 2015). Quality-assurance results for the CAL were accessed at http://nadp.sws.uiuc.edu/lib/qaReports.aspx (accessed February 23, 2015). Data used for this report are listed in the appendix (table 1-1).

Variability in solute concentration, sample volume, and precipitation depth was determined using weekly paired samples flagged with Quality Rating (QR) codes of "A" and "B"; samples flagged with the "C" qualifying QR code for chemical concentrations were not used. The A-coded samples were considered to be valid and useable without limitations, B-coded samples had an unknown but valid quality rating, and C-coded samples were considered invalid. The QR codes were applicable to the chemical concentrations only. Sample volumes and precipitation depths were considered valid for samples with $\mathrm{C}$-coded chemical concentrations. Therefore, all available sample-volume and precipitaiton-depth data were used.

The NADP completeness criteria 1 through 3 were evaluated for each site on a calendar-year basis. Site data records must meet criteria 1, 2, and 3 for inclusion in NADP's annual national map products as follows (National Atmospheric Deposition Program, 2016a):

- Criterion 1.--Valid samples are available for greater than 75 percent of summary period.

- Criterion 2.-Precipitation amounts are available for greater than 90 percent of summary period.

- Criterion 3.-Valid samples are available for greater than 75 percent of the total precipitation amount for summary period.

Before 2010, a fourth criterion (Criterion 4) required at least 75 percent of the precipitation depth recorded by the precipitation gage to be sampled by the collector, also known as 75-percent catch efficiency. Because Criterion 4 is no longer applicable, data for the $\mathrm{CO} 98$ site, and sites at similar high elevations, are now more likely to meet NADP completeness criteria. Consequently, CO98 data met NADP completeness criteria for the first time in 29 years of operation in 2011 and then again in 2012. During the study period, CO89 data met the NADP completeness criteria for 2012.

The $\mathrm{N}_{\text {inorg }}$ concentrations (in milligrams per liter $[\mathrm{mg} / \mathrm{L}]$ as nitrogen [N]) were calculated by summing weekly $\mathrm{NH}_{4}^{+}$ and $\mathrm{NO}_{3}{ }^{-}$concentrations multiplied by the mole fraction of $\mathrm{N}$ for each constituent. No $\mathrm{NH}_{4}^{+}$values and only one $\mathrm{NO}_{3}^{-}$ concentration value were censored at less than the method detection limit (MDL); this single $\mathrm{NO}_{3}{ }^{-}$value was set to the detection limit. Substitutions for censored values can cause subsequently calculated statistical values to be biased (Helsel, 2012, p. 70-77); however, only one value was substituted for the entire 5-water-year record.

Paired relative differences were obtained by subtracting $\mathrm{CO} 89$ site values from CO98 site values. Paired differences (CO98 minus CO89) in weekly concentration, sample volume, and precipitation depth were compared statistically using the Wilcoxon signed rank test (Hollander and Wolfe, 1999) at the $\alpha=0.05$ and $\alpha=0.1$ significance levels (95- and 90-percent confidence, respectively). The R software, version 3.1.2, was used for all statistical determinations. Median relative differences in the colocated measurements were used to evaluate bias between the two collectors (eq. 1). Median absolute percent differences describe the overall measurement variability for the $\mathrm{CO} 89 / \mathrm{CO} 98$ data (eq. 2). 
Median relative difference $=\mathrm{M}\left(C_{\mathrm{oi}}-C_{\mathrm{coi}}\right)$,

where

M is the median of all paired differences for weekly sample pairs $i$ through $j$, where $j$ is the total number of weekly samples for the year;

$C_{\text {coi }} \quad$ is the weekly sample concentration, in milligrams per liter; or weekly sample volume, in milliliters, from the CO89 wetdeposition sampler; or weekly precipitation depth, in millimeters, from the $\mathrm{CO} 89$ rain gage; and

$C_{\mathrm{oi}} \quad$ is the weekly sample concentration, in milligrams per liter; or weekly sample volume, in milliliters, from the CO98 wetdeposition sampler; or weekly precipitation depth from the CO98 rain gage, and

Median absolute difference (in percent)

$$
=\mathrm{M}\left(\frac{\left|C_{\mathrm{oi}}-C_{\mathrm{coi}}\right|}{\left(\frac{C_{\mathrm{oi}}-C_{\mathrm{coi}}}{2}\right)}\right) \times 100
$$

where

M is the median of all paired differences for weekly sample pairs $i$ through $j$, where $j$ is the total number of weekly samples for the year;

$C_{\text {coi }} \quad$ is the weekly sample concentration, in milligrams per liter; or weekly sample volume, in milliliters, from the CO89 wetdeposition sampler; or weekly precipitation depth, in millimeters, from the CO89 rain gage; and

$C_{\mathrm{oi}} \quad$ is the weekly sample concentration, in milligrams per liter; or weekly sample volume, in milliliters, from the CO98 wetdeposition sampler; or weekly precipitation depth from the $\mathrm{CO} 98$ rain gage.

The following equation is used to calculate the water-year precipitation-weighted mean concentrations (PWMCs):

Water-year PWMC (milligrams per liter)

$$
=\left(\frac{\sum_{1}^{w}\left[\left(p p t_{w} \times C_{w}\right)\right]}{\sum_{1}^{w} p p t_{w}}\right)
$$

where

$$
\begin{aligned}
& \text { ppt }_{w} \quad \text { is the weekly precipitation depth associated } \\
& \text { with weekly composite samples, in } \\
& \text { centimeters; }
\end{aligned}
$$

$C_{w} \quad$ is the chemical constituent concentrations, in milligrams per liter, for weekly composite samples; and

$w \quad$ is the number of weeks with samples and associated precipitation depths.

The following equation is used to calculate water-year total deposition using the PWMCs:

$$
\begin{aligned}
& \text { Water-year total constituent deposition } \\
& \quad(\text { kilograms per hectare }) \\
& =\text { PWMC } \times p p t_{\text {water-yr total }} \times 0.1
\end{aligned}
$$

where

PWMC is the water-year precipitation-weighted mean concentration, in milligrams per liter (eq. 3);

$p p t_{\text {water-yr total }}$ is the total precipitation depth measured by precipitation gage for water year, in centimeters; and

0.1 is the conversion factor.

Absolute percent differences in water-year PWMC and totaldeposition values were calculated with respect to the average of the CO89 and CO98 site values, similar to equation 2:

Water-year total deposition absolute percent difference

$$
=\left(\frac{\left|V a l_{\mathrm{CO} 98}-V a l_{\mathrm{CO} 99}\right|}{\left(\frac{V a l_{\mathrm{CO} 98}+V a l_{\mathrm{CO} 99}}{2}\right)}\right) \times 100
$$

where

$$
\begin{aligned}
& \mathrm{Val}_{\mathrm{CO} 98} \text { is the water-year PWMC, in milligrams per } \\
& \text { liter, or total deposition estimated from site } \\
& \text { CO98 record, in kilograms per hectare; and } \\
& \mathrm{Val}_{\text {Co89 }} \text { is the water-year PWMC, in milligrams per } \\
& \text { liter, or total deposition estimated from site } \\
& \text { CO89 record, in kilograms per hectare. }
\end{aligned}
$$

Variability in water-year $\mathrm{N}_{\text {inorg }}$ deposition was determined for values obtained from NADP at $h t t p: / / n a d p . s w s . u i u c . e d u /$ cal/ (accessed January 15, 2016). Two-sample means and standard deviations were calculated for each pair of water-year $\mathrm{N}_{\text {inorg }}$ deposition measurements . Relative standard deviation $(R S D)$ values were calculated for each of the 5 water years by dividing the two-sample standard deviations by the two-sample means as follows. First, the standard deviation of water-year deposition $\left(S D_{\text {wy }}\right)$ is calculated as

$$
S D_{\mathrm{wy}}=\sqrt{\frac{\left(D_{\mathrm{CO98}}-D_{\mathrm{CO} 9}\right)^{2}}{2}},
$$

where

$$
D_{\text {CO89 }} \quad \text { is the inorganic } \mathrm{N} \text { deposition at } \mathrm{CO} 89 \text { for a }
$$
water year, in kilograms per hectare; and 


$$
\begin{gathered}
D_{\mathrm{CO} 98} \quad \text { is the inorganic } \mathrm{N} \text { deposition at } \mathrm{CO} 98 \text { for a } \\
\text { water year, in kilograms per hectare. }
\end{gathered}
$$

Next, the $R S D$ is calculated as

$$
R S D(\text { percent })=100 \times \frac{S D_{\text {wy }}}{\bar{D}},
$$

where

$$
\begin{array}{ll}
S D_{\text {wy }} & \text { is the standard deviation of water-year } \\
\text { deposition (eq. 6) and } \\
\bar{D} & \text { is the mean of } D_{\text {C089 }} \text { and } D_{\text {CO98 }} \text { for a water } \\
& \text { year. }
\end{array}
$$

Two measurements are considered significantly different if their confidence intervals do not overlap. Confidence limits for annual $\mathrm{N}_{\text {inorg }}$ deposition measurements and critical load goals were estimated using the following equation:

$$
D_{\mathrm{CL}}=D_{\text {measured }} \times\left[1-Z_{1-\alpha} \times \frac{R S D_{\text {Avg }}}{100}\right] \text {, }
$$

where

$$
\begin{array}{ll}
D_{\mathrm{CL}} & \text { is the confidence limit at significance level of } \\
& \alpha \text { for measured deposition, in kilograms } \\
& \text { per hectare; } \\
D_{\text {measured }} & \text { is the measured inorganic nitrogen deposition } \\
& \text { or hypothetical deposition goal, in } \\
& \text { kilograms per hectare; } \\
Z & \text { is } 1.282 \text { for one-tailed, } 90 \text {-percent confidence } \\
& (\alpha=0.10) \text { limits; and } \\
R S D_{\text {Avg }} & \text { is the average } R S D \text { of inorganic N deposition } \\
& \text { for } 5 \text { water years (eq. 7). }
\end{array}
$$

\section{Evaluation of Colocated Measurements}

The NADP updates its databases as quality-assurance information is obtained and new data-management policies are adopted. Previous USGS cooperator reports to NPS used various quality indicator fields from the CAL database to make preliminary determinations of sample validity (for example, Morris and others, 2015). Since 2014, these indicators have been enveloped into QR codes A, B, and C assigned to the sample data by the NADP. Therefore, percentages of valid samples, precipitation amounts, and other quality indicators are updated herein compared to previous cooperator reports provided by USGS to the NPS for this monitoring activity.

An inventory of wet-deposition samples collected at CO89 and CO98 for water years 2010-14 indicates that the proportion of the total number of collected A-coded samples increased for water years 2012-13 compared to 2010-11 for both sites, while the proportion of C-coded samples declined for both sites (fig. 2, table 1). The proportion of C-coded samples collected at CO98 increased for water years $2012-14$ compared to $2010-11$. The NADP assigns "Inval" codes to data to denote reasons for data invalidation (National Atmospheric Deposition Program, 2016a). Based on "Inval" code assignments, the increases in C-coded samples for CO98 during 2012-14 were primarily due to extended sampling intervals greater than 8 days ( 5 samples), samples with inadequate volume (5 samples), and undefined reasons (17 samples).

An evaluation of data completeness by calendar year per NADP completeness criteria 1, 2, and 3 is summarized in table 2. Data for sites CO89 and CO98 met Criterion 1 in calendar years 2011 and 2012. Although the remote Loch Vale site has some of the most extreme weather conditions in the
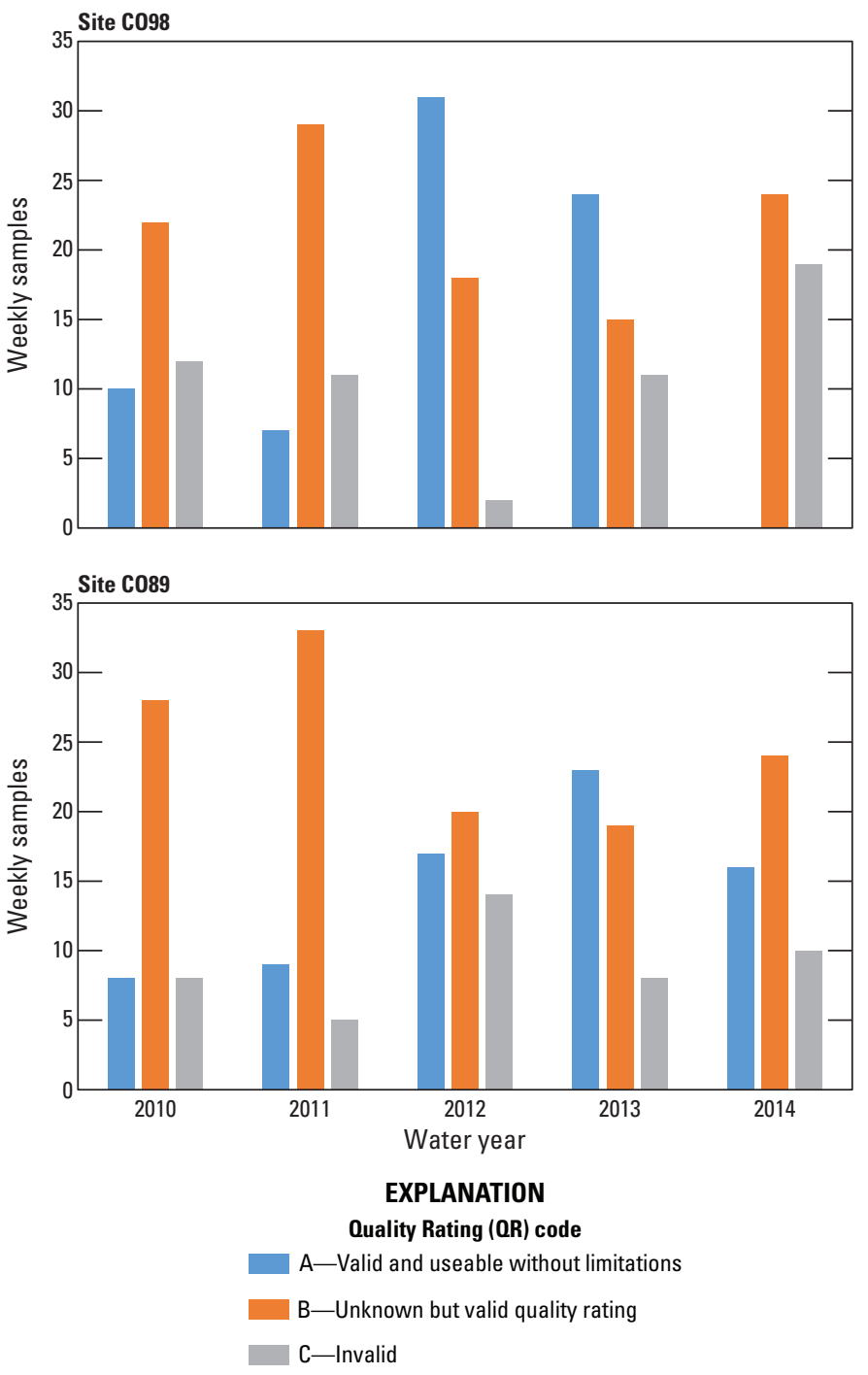

Figure 2. Frequency of samples with $A, B$, and C Quality Rating (QR) codes for National Atmospheric Deposition Program/National Trends Network weekly samples collected at colocated sites C089 and C098, Loch Vale, Rocky Mountain National Park, water years 2010-14. 
Table 1. Wet-deposition sample types collected at National Atmospheric Deposition Program/National Trends Network sites C089 and C098, Loch Vale, Rocky Mountain National Park, water years 2010-14.

[mL, milliliters]

\begin{tabular}{|c|c|c|c|c|c|}
\hline \multirow{2}{*}{ Sample type descriptions } & \multicolumn{5}{|c|}{ Water years } \\
\hline & 2010 & 2011 & 2012 & 2013 & 2014 \\
\hline \multicolumn{6}{|c|}{ Site C089 } \\
\hline Dry weeks & 6 & 0 & 2 & 3 & 2 \\
\hline Trace sample of less than $10 \mathrm{~mL}$ with incomplete analyses & 0 & 2 & 6 & 3 & 3 \\
\hline Sample volume less than $35 \mathrm{~mL}$, dilution required & 2 & 1 & 1 & 2 & 1 \\
\hline Sample of approximately $35 \mathrm{~mL}$ or more & 36 & 44 & 42 & 42 & 44 \\
\hline Undefined/missed & 8 & 5 & 1 & 2 & 2 \\
\hline \multicolumn{6}{|c|}{ Site C098 } \\
\hline Dry weeks & 6 & 0 & 3 & 1 & 1 \\
\hline Trace sample of less than $10 \mathrm{~mL}$ with incomplete analyses & 1 & 2 & 3 & 6 & 8 \\
\hline Sample volume less than $35 \mathrm{~mL}$, dilution required & 1 & 1 & 2 & 4 & 3 \\
\hline Sample of approximately $35 \mathrm{~mL}$ or more & 36 & 44 & 43 & 39 & 38 \\
\hline Undefined/missed & 8 & 5 & 1 & 2 & 2 \\
\hline
\end{tabular}

Table 2. Precipitation depths measured with wet-deposition samples for colocated sites C089 and C098, Loch Vale, Rocky Mountain National Park, calendar years 2010-14.

[Percentages for site CO89 for all years and for site CO98 for 2014 were determined by U.S. Geological Survey and are not official National Atmospheric Deposition Program values. cm, centimeters; \%, percent]

\begin{tabular}{|c|c|c|c|c|c|}
\hline $\begin{array}{c}\text { Calendar } \\
\text { year }\end{array}$ & $\begin{array}{l}\text { Precipitation depth } \\
\text { represented by weekly } \\
\text { wet-deposition samples } \\
\text { (cm) }\end{array}$ & $\begin{array}{l}\text { Total measured } \\
\text { precipitation depth } \\
\text { (cm) }\end{array}$ & $\begin{array}{l}\text { Percentage of year } \\
\text { represented by weekly } \\
\text { wet-deposition samples } \\
\text { (Criterion 1: } 75 \% \text { ) }\end{array}$ & $\begin{array}{l}\text { Percentage of total } \\
\text { annual precipitation } \\
\text { depth record obtained }{ }^{1} \\
\text { (Criterion } 2: 90 \% \text { ) }\end{array}$ & $\begin{array}{l}\text { Percentage of total annual } \\
\text { precipitation depth } \\
\text { represented by weekly } \\
\text { wet-deposition samples } \\
\text { (Criterion } 3: 75 \% \text { ) }\end{array}$ \\
\hline \multicolumn{6}{|c|}{ Site C089 } \\
\hline 2010 & 129.4 & 135.4 & 69 & 99 & 80 \\
\hline 2012 & 69.2 & 91.5 & 77 & 100 & 76 \\
\hline 2013 & 81.2 & 140.4 & 72 & 99 & 58 \\
\hline 2014 & 104.7 & 152.0 & 63 & 96 & ${ }^{2} 69$ \\
\hline \multicolumn{6}{|c|}{ Site C098 } \\
\hline 2010 & 82.9 & 132.0 & 69 & 100 & 62 \\
\hline 2013 & 80.7 & 140.8 & 66 & 100 & 57 \\
\hline 2014 & 102.7 & 152.5 & 61 & 96.2 & 51 \\
\hline
\end{tabular}

${ }^{1}$ Based on substitution of missing records between gages for approximately 60 days during 2013 .

${ }^{2}$ Partial year due to discontinued sampling in October 2014. 
NADP/NTN (Baron and Mast, 1992), the sample collection for 20 of the 32 years of $\mathrm{CO} 98$ operation was greater than 75 percent complete (Criterion 1).

The precipitation-gage data fell short of Criterion 2 (90 percent) during 2011 and 2013. Any NADP-approved rain gage within $30 \mathrm{~m}$ of a collector may be used to collect precipitation record for an NADP site (National Atmospheric Deposition Program, 2014); therefore, measured precipitation depths were substituted for missing records between the CO89 and CO98 gages to obtain more complete records for each gage, primarily during 2011 and 2013. Precipitation records were substituted between the gages for only a few days in 2011, but during 2013, records were substituted approximately 37 days during April-June 2013, 20 days during August 2013, and 3 days during December 2013.

During 2010-14, Criterion 3 (75 percent of precipitation depth represented by valid samples) was met for site CO89 in 2010 and 2012 only and for CO98 in 2011 and 2012 only. Data for site CO98 met Criterion 3 for 21 of 31 years of operation. The site CO98 data met all of the NADP completeness criteria for the first time in 28 years of operation in 2011 and then again in 2012.

Criterion 4, which required that the annual collector catch efficiency to be at least 75 percent for the entire calendar year, has not been required by NADP since 2009. Catch efficiency is calculated using the following equation:

$$
=\left(\frac{\text { Collector precipitation depth }}{\text { Rain-gage precipitation depth }}\right) \times 100,
$$

Excluding Criterion 4, the CO98 site would have met all currently required NADP completeness criteria for 19 of 31 years during 1983-2014. Completeness criteria are used to include only sites with sufficient data for spatial interpolation of wet-deposition values in the NADP's annual map series. Data are still useful for estimation of annual deposition even when completeness criteria are not met.

\section{Evaluation of Measurement Bias and Variability}

Median relative CO98-minus-CO89 (signed) differences and median absolute percent differences for the weekly colocated samples were calculated for water years 2010-14 (table 3). For comparison purposes, median absolute percent differences from previous NADP colocated equipment studies (Wetherbee and others, 2005, table 2) were also included. Results of the Wilocoxon signed rank test identified statistically significant bias between the data from sites CO89 and CO98.

\section{Bias}

Weekly concentrations of $\mathrm{NH}_{4}^{+}, \mathrm{NO}_{3}^{-}$, and $\mathrm{N}_{\text {inorg }}$ usually were higher for site $\mathrm{CO} 98$ than site CO89. Median differences in weekly $\mathrm{NH}_{4}^{+}$concentration values were not significantly different from zero (Wilcoxon signed rank test at $\alpha=0.10$ ) in water years $2010-13$ but were significantly different from zero in water year 2014 (table 3). Median relative differences for weekly $\mathrm{NO}_{3}{ }^{-}$and $\mathrm{N}_{\text {inorg }}$ concentration values were significantly different from zero in water years 2010, 2011, and 2014 but not in water years 2012 and 2013. Weekly median relative sample volume and precipitation-depth differences were significantly different from zero in water years 2010, 2012, and 2013 but not in water years 2011 and 2014 (Wilcoxon signed rank test at $\alpha=0.10$ ).

Statistically significant differences in weekly precipitation depths ranged from 0 to -0.25 millimeter (table 3 ). Median weekly relative concentration differences for $\mathrm{NH}_{4}^{+}$ and $\mathrm{NO}_{3}{ }^{-}$concentrations were similar to CAL's method detection limits, which ranged from 0.005 to $0.016 \mathrm{mg} / \mathrm{L}_{\text {for }} \mathrm{NH}_{4}^{+}$ and from 0.004 to $0.025 \mathrm{mg} / \mathrm{L}_{\text {for }} \mathrm{NO}_{3}{ }^{-}$during 2010-13. The exception is the median $\mathrm{NO}_{3}{ }^{-}$concentration difference during 2014, which was more than two times the method detection limit for $2013(0.025 \mathrm{mg} / \mathrm{L})$.

\section{Variability}

Median weekly absolute differences were all 11 percent or less for all parameters (table 3). Median absolute differences for weekly $\mathrm{NH}_{4}{ }^{+}$and $\mathrm{NO}_{3}{ }^{-}$concentrations were less than the median absolute differences for 41 colocated sites across the United States (Wetherbee and others, 2005) except for $\mathrm{NO}_{3}{ }^{-}$concentrations in water year 2014. Median absolute percent differences for weekly sample volumes were approximately 2 to 3 times higher for the CO89 and CO98 sites compared to the median absolute differences for 41 colocated sites across the United States. This outcome was not unexpected considering the snowy and windy conditions at Loch Vale, which are extreme relative to all of the other sites included in the USGS colocated sampler program (Wetherbee and others, 2005). Wind-blown snow is typically subject to undercatch by precipitation gages and sample collectors (Weiss, 1961; Yang and others, 1998; Fassnacht, 2004). More variability in sample precipitation-depth and sample-volume differences for weeks with only snow than for weeks with only rain was noted (fig. 3).

Data distributions for weekly sample-volume and precipitation-depth differences were noted by water year (fig. 4). Median weekly absolute differences ranged from 7.3 to $39.4 \mathrm{~mL}$ ( 5 to 10 percent) for sample volume and from 0 to 0.25 millimeter ( 0 to 0.3 percent) for precipitation depth. Data distributions for weekly concentration differences were noted by water year (fig. 5) Weekly $\mathrm{NH}_{4}^{+}$concentration differences have low variability, but several outside values for $\mathrm{NO}_{3}{ }^{-}$concentration differences were greater than $0.5 \mathrm{mg} / \mathrm{L}$. 
Table 3. Weekly colocated sampler concentration differences and results of Wilcoxon signed rank test for valid paired samples collected at National Atmospheric Deposition Program (NADP)/National Trends Network sites C089 and C098, water years 2010-14, and comparison to results from previous studies at other NADP sites from across the United States, water years 1989-2001.

[Water year is the 12-month period from October 1 through September 30 of the following year and is designated by the calendar year in which it ends. $\mathrm{NH}_{4}^{+}$, ammonium; $\mathrm{NO}_{3}^{-}$, nitrate; $\mathrm{N}_{\text {inorg }}$, inorganic nitrogen; $\mathrm{mg} / \mathrm{L}$, milligram per liter; <, less than; $\mathrm{mL}$, milliliters; mm, millimeter; $p$-value, probability of incorrectly concluding that the median difference is zero; --, no data. Shaded values identify significant differences at $\alpha=0.10]$

\begin{tabular}{|c|c|c|c|c|c|}
\hline $\begin{array}{c}\text { Water } \\
\text { year }\end{array}$ & $\begin{array}{l}\text { Parameter } \\
\text { (units) }\end{array}$ & $\begin{array}{l}\text { Weekly median } \\
\text { relative difference } \\
\text { (units) }\end{array}$ & $\begin{array}{l}\text { Median of weekly } \\
\text { absolute differences } \\
\text { (percent) }\end{array}$ & $\begin{array}{c}\text { Wilcoxon signed } \\
\text { rank test for weekly } \\
\text { pairs } \\
(p \text {-value })\end{array}$ & $\begin{array}{c}\text { Median absolute } \\
\text { differences for } 41 \\
\text { colocated sampler } \\
\text { sites from across } \\
\text { the United States } \\
\text { (1989-2001) } \\
\text { (percent) }{ }^{1}\end{array}$ \\
\hline 2010 & $\mathrm{NH}_{4}^{+}(\mathrm{mg} / \mathrm{L})^{2}$ & 0.003 & 11 & 0.2020 & 11.3 \\
\hline 2011 & $\mathrm{NH}_{4}^{+}(\mathrm{mg} / \mathrm{L})^{2}$ & 0.004 & 11 & 0.3778 & 11.3 \\
\hline 2012 & $\mathrm{NH}_{4}^{+}(\mathrm{mg} / \mathrm{L})^{2}$ & 0.005 & 7 & 0.7897 & 11.3 \\
\hline 2013 & $\mathrm{NH}_{4}^{+}(\mathrm{mg} / \mathrm{L})^{2}$ & 0.004 & 7 & 0.4889 & 11.3 \\
\hline 2014 & $\mathrm{NH}_{4}^{+}(\mathrm{mg} / \mathrm{L})^{2}$ & 0.004 & 8 & 0.0557 & 11.3 \\
\hline 2010 & $\mathrm{NO}_{3}^{-}(\mathrm{mg} / \mathrm{L})^{2}$ & 0.036 & 6 & 0.0014 & 10.4 \\
\hline 2011 & $\mathrm{NO}_{3}^{-}(\mathrm{mg} / \mathrm{L})^{2}$ & 0.032 & 8 & 0.0001 & 10.4 \\
\hline 2012 & $\mathrm{NO}_{3}^{-}(\mathrm{mg} / \mathrm{L})^{2}$ & 0.013 & 7 & 0.7366 & 10.4 \\
\hline 2013 & $\mathrm{NO}_{3}^{-}(\mathrm{mg} / \mathrm{L})^{2}$ & 0.006 & 7 & 0.3764 & 10.4 \\
\hline 2014 & $\mathrm{NO}_{3}^{-}(\mathrm{mg} / \mathrm{L})^{2}$ & 0.056 & 11 & $<0.0001$ & 10.4 \\
\hline 2010 & $\mathrm{~N}_{\text {inorg }}(\mathrm{mg} / \mathrm{L})$ & 0.017 & 8 & 0.0050 & -- \\
\hline 2011 & $\mathrm{~N}_{\text {inorg }}(\mathrm{mg} / \mathrm{L})$ & 0.011 & 9 & 0.0218 & -- \\
\hline 2012 & $\mathrm{~N}_{\text {inorg }}(\mathrm{mg} / \mathrm{L})$ & 0.008 & 5 & 0.5017 & -- \\
\hline 2013 & $\mathrm{~N}_{\text {inorg }}(\mathrm{mg} / \mathrm{L})$ & 0.006 & 6 & 0.8512 & -- \\
\hline 2014 & $\mathrm{~N}_{\text {inorg }}(\mathrm{mg} / \mathrm{L})$ & 0.014 & 9 & 0.0033 & -- \\
\hline 2010 & Sample volume (mL) & 11.7 & 7 & 0.0798 & 3.2 \\
\hline 2011 & Sample volume $(\mathrm{mL})$ & 18.7 & 10 & 0.1024 & 3.2 \\
\hline 2012 & Sample volume (mL) & 39.4 & 8 & $<0.0001$ & 3.2 \\
\hline 2013 & Sample volume $(\mathrm{mL})$ & 21.8 & 8 & 0.0037 & 3.2 \\
\hline 2014 & Sample volume (mL) & 7.3 & 5 & 0.7498 & 3.2 \\
\hline 2010 & Precipitation depth $(\mathrm{mm})$ & -0.25 & 0 & 0.0199 & 3.8 \\
\hline 2011 & Precipitation depth (mm) & 0 & 0 & 0.3943 & 3.8 \\
\hline 2012 & Precipitation depth (mm) & 0 & 0 & 0.0592 & 3.8 \\
\hline 2013 & Precipitation depth (mm) & 0 & 0.3 & 0.0438 & 3.8 \\
\hline 2014 & Precipitation depth (mm) & 0 & 0.3 & 0.4150 & 3.8 \\
\hline
\end{tabular}

${ }^{1}$ Wetherbee and others, 2005.

${ }^{2}$ Ranges of method detection limits: ammonium, 0.005-0.016 mg/L; nitrate, 0.004-0.025 mg/L. 


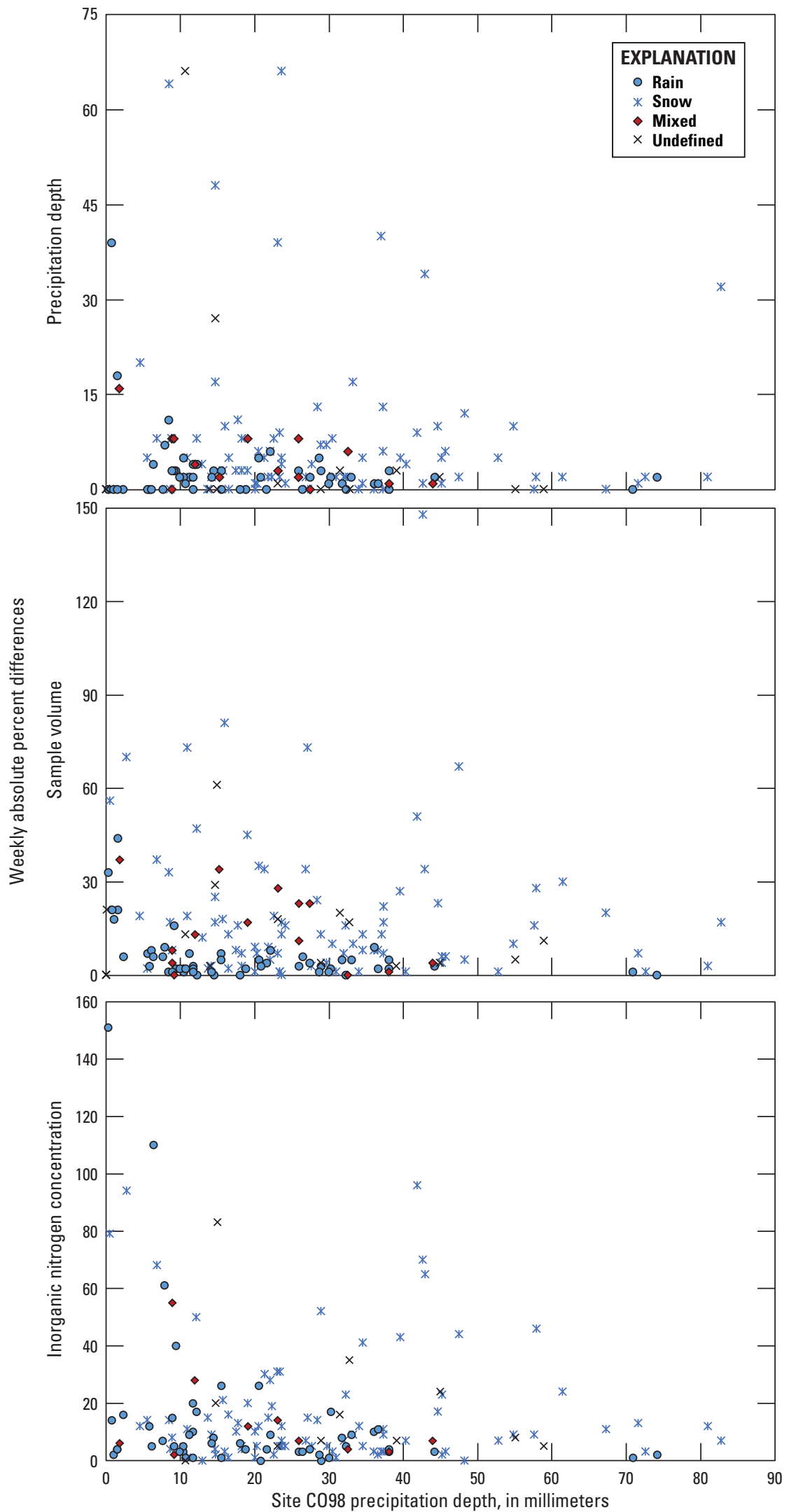

Figure 3. Weekly precipitation-depth, sample-volume, and inorganic nitrogen concentration absolute percent differences by precipitation type for colocated National Atmospheric Deposition Program/National Trends Network sites C098 and C089, water years 2010-14. 

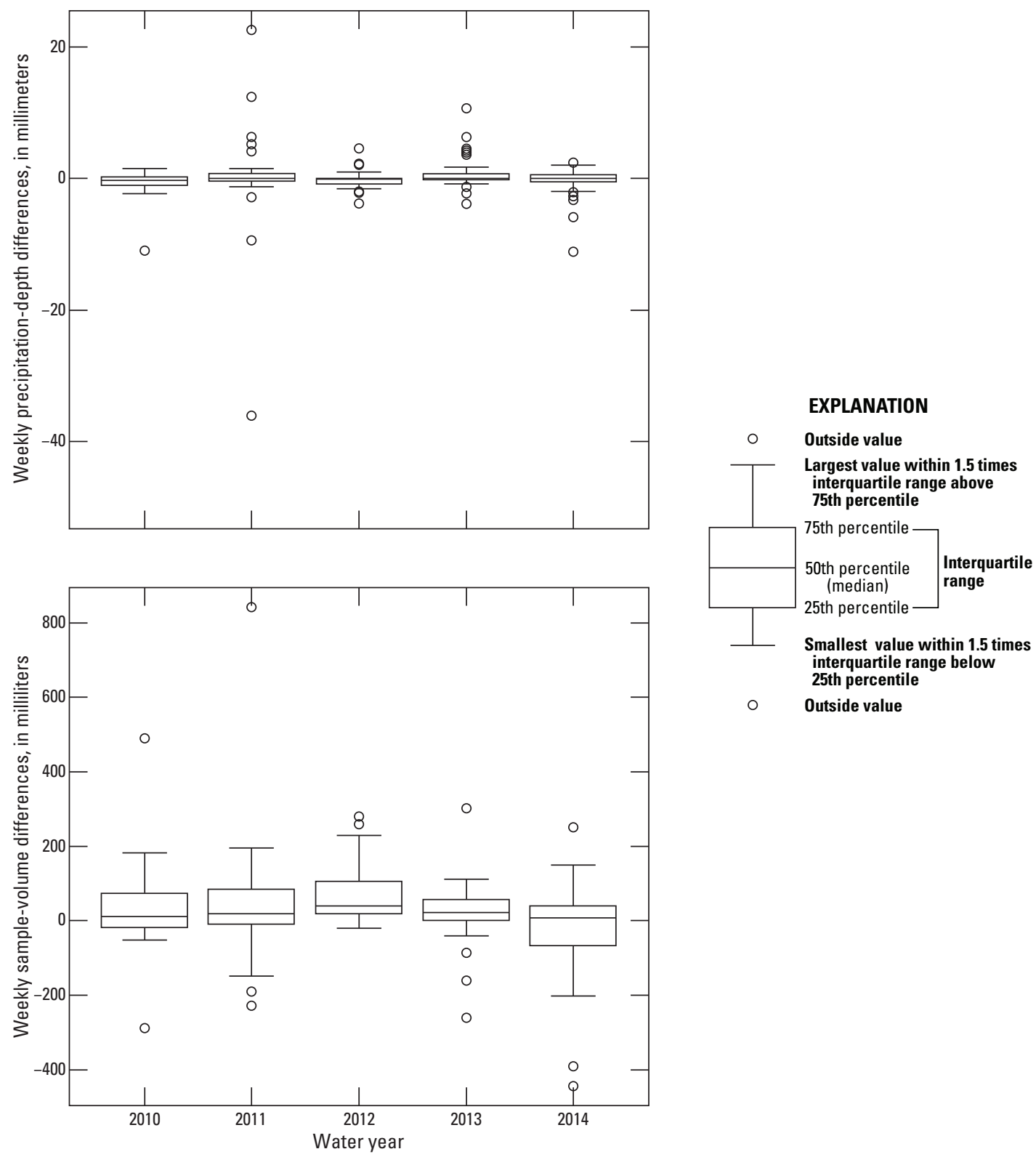

Outside value

Figure 4. Weekly relative precipitation-depth and sample-volume (C098 minus C089) differences for colocated National Atmospheric Deposition Program/National Trends Network sites C098 and C089, water years 2010-14. 


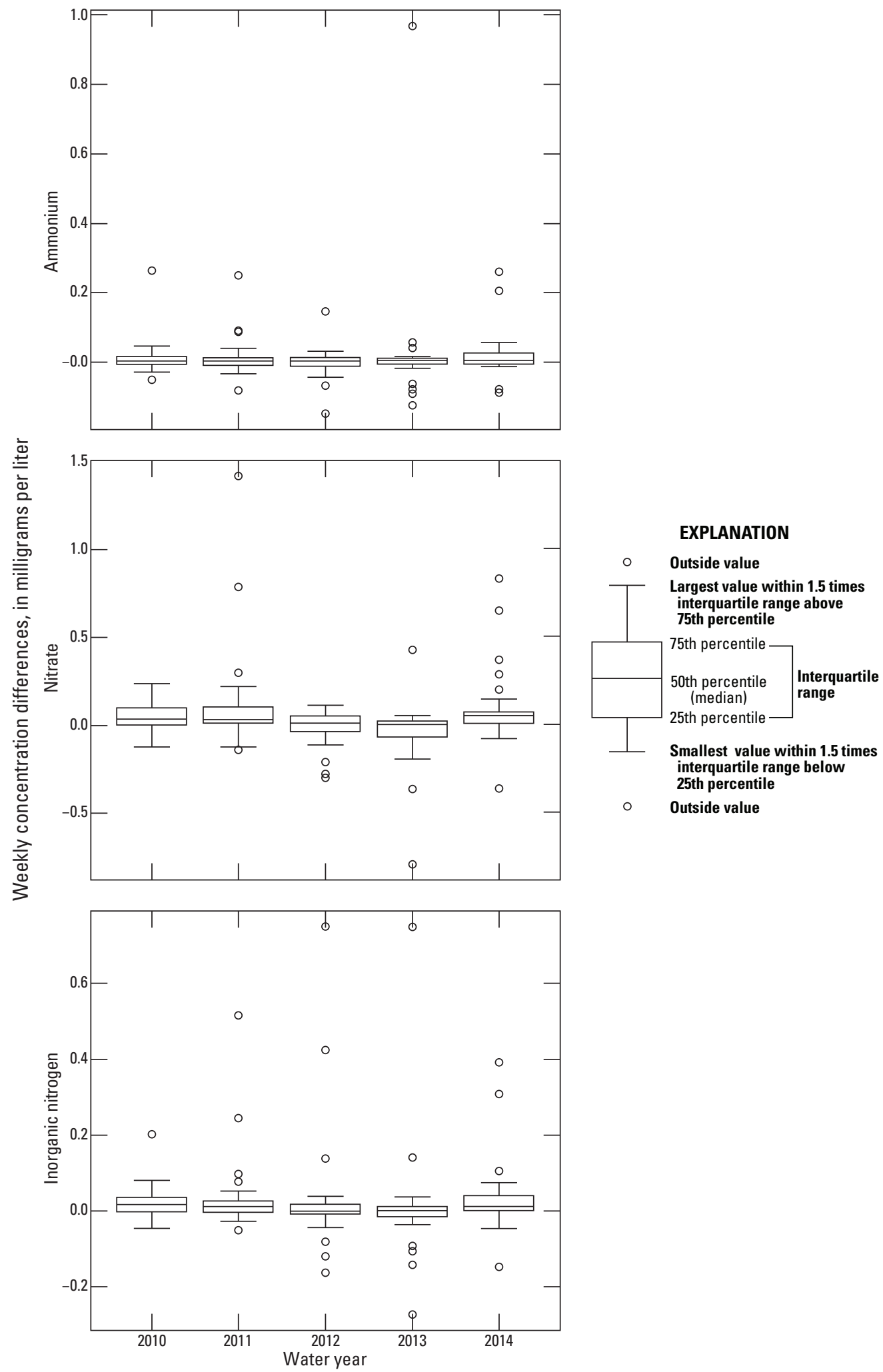

Figure 5. Weekly relative ammonium, nitrate, and inorganic nitrogen concentration (C098 minus C089) differences for colocated National Atmospheric Deposition Program/ National Trends Network sites C098 and C089, water years 2010-14. 
The interquartile ranges for $\mathrm{NO}_{3}^{-}$concentration differences indicated that approximately 67 percent of the weekly samples exhibited concentration differences less than plus or minus $0.1 \mathrm{mg} / \mathrm{L}$ (fig. 5).

The Kruskal-Wallis test was used to evaluate the statistical significance among water years for weekly paired relative $\mathrm{NH}_{4}^{+}, \mathrm{NO}_{3}^{-}$, and $\mathrm{N}_{\text {inorg }}$ concentration, precipitation-depth, and sample volume differences (table 4). Significant differences were identified at the $\alpha=0.05$ significance level for water-year $\mathrm{NH}_{4}^{+}$concentration relative percent difference, $\mathrm{NO}_{3}{ }^{-}$concentration difference, and sample-volume and precipitation-depth differences. Significant differences were identified at the $\alpha=0.10$ significance level for $\mathrm{NO}_{3}^{-}$concentration relative percent difference ( $p$-value $=0.0562)$ and $\mathrm{N}_{\text {inorg }}$ concentration difference ( $p$-value $=0.0529)$. No significant differences between water years were identified for $\mathrm{NH}_{4}^{+}$concentration differences $(p$-value $=0.8140)$.

Water-year PWMCs, total (annual) deposition values, and absolute percent differences between the CO89 and CO98 values (eq. 3, 4, and 5) were calculated (table 5). PWMCs or total deposition amounts for $\mathrm{NO}_{3}^{-}$or $\mathrm{N}_{\text {inorg }}$ were higher for $\mathrm{CO} 98$ than for CO89 for every water year except 2012 and 2013; however, seven weekly samples from CO89 and nine samples from $\mathrm{CO} 98$ were invalidated or missed because of equipment and (or) power problems, sample contamination, and a major flood in September 2013 that closed the park and prevented sample collection. Therefore, some values for water year 2013 measurements are not representative of normal operating conditions for the colocated sites, which indicates the importance of operating colocated site CO89 for several years.

Observed absolute percent differences were less than 4 percent for $\mathrm{NH}_{4}^{+} \mathrm{PWMC}$ and less than 8 percent for $\mathrm{NH}_{4}^{+}$total deposition for all years except 2011, when differences for all parameters were much higher than the rest of the study period. Absolute percent differences ranged from 7.0 to 25.7 percent for $\mathrm{NO}_{3}^{-} \mathrm{PWMC}$ and from 3.3 to 24.5 percent for $\mathrm{NO}_{3}^{-}$annual deposition. Absolute percent differences ranged from 2.4 to 21.1 percent for $\mathrm{N}_{\text {inorg }}$ PWMC and from 0.3 to 17.4 percent for $\mathrm{N}_{\text {inorg }}$ annual deposition. Greater differences were observed for $\mathrm{NO}_{3}^{-} \mathrm{PWMC}$ and total deposition than for $\mathrm{NH}_{4}^{+}$and $\mathrm{N}_{\text {inorg, }}$, most likely because weekly $\mathrm{NO}_{3}{ }^{-}$concentrations are higher than $\mathrm{NH}_{4}^{+}$concentrations, but $\mathrm{NO}_{3}^{-}$also could be less stable than $\mathrm{NH}_{4}^{+}$in the unpreserved wet-deposition samples. A study by the CAL and NADP Program Office indicated that $\mathrm{NO}_{3}^{-}$ concentrations were affected by sample evaporation more so than $\mathrm{NH}_{4}^{+}$concentrations in controlled experiments (Rhodes and others, 2011; Mark Rhodes, written commun., 2015). Greater differences can also result from sample contamination.

Table 4. Kruskal-Wallis test values for differences among water years 2010-14 for weekly National Atmospheric Deposition Program/National Trends Network sites CO89 and CO98.

[df, degrees of freedom; $\mathrm{NH}_{4}^{+}$, ammonium; $\mathrm{NO}_{3}^{-}$, nitrate; $\mathrm{N}_{\text {inorg }}$, inorganic nitrogen; $p$-value, probability of incorrectly concluding that the median difference is zero; $<$, less than. Shaded values denote statistically significant differences between water years at $\alpha=0.05$ significance level]

\begin{tabular}{lccc}
\hline \multicolumn{1}{c}{ Parameter } & Chi-squared & df & $\boldsymbol{p}^{-v a l u e} \mathbf{1}^{\mathbf{1}}$ \\
\hline $\mathrm{NH}_{4}{ }^{+}$concentration relative percent difference & 11.8 & 4 & 0.0187 \\
$\mathrm{NH}_{4}{ }^{+}$concentration difference & 1.57 & 4 & 0.8140 \\
$\mathrm{NO}_{3}{ }^{-}$concentration relative percent difference & 9.20 & 4 & 0.0562 \\
$\mathrm{NO}_{3}{ }^{-}$concentration difference & 19.7 & 4 & $<0.0001$ \\
$\mathrm{~N}_{\text {inorg }}$ concentration relative percent difference & 9.35 & 4 & 0.0529 \\
$\mathrm{~N}_{\text {inorg }}$ concentration difference & 8.06 & 4 & 0.0893 \\
Precipitation-depth relative percent difference & 10.7 & 4 & 0.0307 \\
Precipitation-depth difference & 14.2 & 4 & 0.0066 \\
Sample-volume relative percent difference & 13.6 & 4 & 0.0085 \\
Sample-volume difference & 13.1 & 4 & 0.0109 \\
\hline
\end{tabular}

${ }^{1}$ null hypothesis: There is no difference among water years with respect to weekly concentration, precipitationdepth, and sample-volume differences. 
Table 5. Water-year precipitation-weighted mean concentrations and total deposition values for National Atmospheric Deposition Program/National Trends Network sites C089 and C098, water years 2010-14.

[PWMC, precipitation-weighted mean concentration; mg/L, milligrams per liter; $\mathrm{kg} / \mathrm{ha}$, kilograms per hectare; $\mathrm{NH}_{4}^{+}$, ammonium; $\mathrm{NO}_{3}^{-}$, nitrate; $\mathrm{N}_{\text {inorg, }}$, inorganic nitrogen]

\begin{tabular}{|c|c|c|c|c|c|c|}
\hline \multirow{2}{*}{ Analyte } & \multicolumn{2}{|c|}{$\begin{array}{l}\text { Water-year PWMC } \\
\text { (mg/L) }\end{array}$} & \multirow{2}{*}{$\begin{array}{l}\text { Water-year } \\
\text { PWMC absolute } \\
\text { differences } \\
\text { (percent) }\end{array}$} & \multicolumn{2}{|c|}{$\begin{array}{l}\text { Water-year total deposition } \\
\text { (kg/ha) }\end{array}$} & \multirow{2}{*}{$\begin{array}{l}\text { Water-year total } \\
\text { deposition abso- } \\
\text { lute differences } \\
\text { (percent) }\end{array}$} \\
\hline & CO89 & CO98 & & CO89 & C098 & \\
\hline \multicolumn{7}{|c|}{ Water year 2010} \\
\hline $\mathrm{NH}_{4}^{+}$ & 0.148 & 0.143 & 3.4 & 1.81 & 1.68 & 7.4 \\
\hline $\mathrm{NO}_{3}^{-}$ & 0.568 & 0.609 & 7.0 & 6.94 & 7.17 & 3.3 \\
\hline $\mathrm{N}_{\text {inorg }}$ & 0.243 & 0.249 & 2.4 & 2.97 & 2.93 & 1.4 \\
\hline \multicolumn{7}{|c|}{ Water year 2011} \\
\hline $\mathrm{NH}_{4}^{+}$ & 0.103 & 0.129 & 22.4 & 1.58 & 1.91 & 18.9 \\
\hline $\mathrm{NO}_{3}^{-}$ & 0.491 & 0.600 & 20.0 & 7.52 & 8.89 & 16.7 \\
\hline $\mathrm{N}_{\text {inorg }}$ & 0.191 & 0.236 & 21.1 & 2.93 & 3.49 & 17.4 \\
\hline \multicolumn{7}{|c|}{ Water year 2012} \\
\hline $\mathrm{NH}_{4}^{+}$ & 0.175 & 0.171 & 2.3 & 1.77 & 1.68 & 5.2 \\
\hline $\mathrm{NO}_{3}^{-}$ & 0.638 & 0.589 & 8.0 & 6.46 & 5.77 & 11.3 \\
\hline $\mathrm{N}_{\text {inorg }}$ & 0.280 & 0.266 & 5.1 & 2.84 & 2.61 & 8.4 \\
\hline \multicolumn{7}{|c|}{ Water year 2013} \\
\hline $\mathrm{NH}_{4}^{+}$ & 0.256 & 0.247 & 3.6 & 3.33 & 3.26 & 2.1 \\
\hline $\mathrm{NO}_{3}^{-}$ & 0.782 & 0.604 & 25.7 & 10.18 & 7.96 & 24.5 \\
\hline $\mathrm{N}_{\text {inorg }}$ & 0.376 & 0.329 & 13.3 & 4.89 & 4.33 & 12.1 \\
\hline \multicolumn{7}{|c|}{ Water year 2014} \\
\hline $\mathrm{NH}_{4}^{+}$ & 0.146 & 0.146 & 0.0 & 2.11 & 2.02 & 4.4 \\
\hline $\mathrm{NO}_{3}^{-}$ & 0.414 & 0.458 & 10.1 & 5.97 & 6.34 & 6.0 \\
\hline $\mathrm{N}_{\text {inorg }}$ & 0.207 & 0.217 & 4.7 & 2.99 & 3.00 & 0.3 \\
\hline
\end{tabular}




\section{Confidence Limits for Annual Deposition Measurements}

Deposition of $\mathrm{N}_{\text {inorg }}$ was calculated for water years 2010 14 (table 6). Relative standard deviations (RSDs) between the two gages were less than 10 percent for all water years except 2011 , when the $R S D$ was 12.3 percent. The average $R S D$ $\left(R S D_{\text {Avg }}\right)$ for the 5 water years was 5.6 percent.

\section{Application of Annual Deposition Confidence Limits for Rocky Mountain National Park}

The NDRP requires comparison of annual $\mathrm{N}_{\text {inorg }}$ wetdeposition measurements at site CO98 to pentennial wetdeposition goals along a 25-year glidepath beginning in 2006 and ending in 2032 (National Park Service, 2007). Annual $\mathrm{N}_{\text {inorg }}$ measurements at sites CO89 and CO98 for water years 2010-14 were used to calculate confidence limits for future site CO98 $\mathrm{N}_{\text {inorg }}$ measurements. The confidence limits provide a means to determine when NDRP wet-deposition goals are met or exceeded.

Calculated confidence limits for $\mathrm{N}_{\text {inorg }}$ deposition goals for the NDRP glidepath are listed in table 7. Results in table 7 are calculated by substituting the measured deposition for 2006 and the pentennial goals of the glidepath for $\mathrm{N}_{\text {inorg }}$ deposition into equation 8. Significance was evaluated as a one-tail test to estimate confidence in measuring the exceedance of $\mathrm{N}_{\text {inorg }}$ deposition goals, such as the pentennial glidepath goals, including the accepted critical load of $1.5 \mathrm{~kg} / \mathrm{ha}$.

Repeating the calculations using a $Z$ value for the $\alpha=0.05$ significance level (95-percent confidence) does not change the upper and lower confidence limit estimates for a deposition value of $1.5 \mathrm{~kg} \mathrm{~N} / \mathrm{ha}$ for $\mathrm{N}_{\text {inorg }}(1.4 \mathrm{~kg} \mathrm{~N} / \mathrm{ha}$ and $1.6 \mathrm{~kg} / \mathrm{ha}$, respectively), but estimates for other glidepath goals in years 2012-27 increase by $0.1 \mathrm{~kg} \mathrm{~N} / \mathrm{ha}$. For example, in the year 2017, the 90-percent lower and upper confidence limits for a deposition measurement goal of $2.4 \mathrm{~kg} \mathrm{~N} /$ ha are $2.2 \mathrm{~kg} \mathrm{~N} / \mathrm{ha}$ and $2.6 \mathrm{~kg} \mathrm{~N} /$ ha, respectively (table 7), and the 95 -percent $(\alpha=0.05)$ confidence limits are $2.3 \mathrm{~kg} \mathrm{~N} / \mathrm{ha}$ and $2.7 \mathrm{~kg} \mathrm{~N} / \mathrm{ha}$, respectively (not shown).

The confidence limits for the site CO98 measurements of annual $\mathrm{N}_{\text {inorg }}$ could change in response to site instrumentation changes; variability in site equipment maintenance; and potential changes in sample handling, processing, shipping, and chemical analysis. These may be important considerations because the NDRP is projected to operate for another 16 years, during which instrumentation will likely be refurbished or replaced, and different personnel will be responsible for the program's implementation. Changes in data-collection protocols and (or) instrumentation could necessitate another colocated site study to re-evaluate measurement variability.

Table 6. Annual inorganic nitrogen deposition measured at National Atmospheric Deposition Program sites C089 and C098, Loch Vale, Rocky Mountain National Park, water years 2010-14.

$\left[\mathrm{kg} \mathrm{N} / \mathrm{ha}\right.$, kilograms of inorganic nitrogen per hectare; $R S D_{\text {Avg }}$, average relative standard deviation; MAD, median absolute difference]

\begin{tabular}{|c|c|c|c|c|c|c|}
\hline \multirow{2}{*}{$\begin{array}{l}\text { Water } \\
\text { year }\end{array}$} & \multicolumn{2}{|c|}{$\begin{array}{c}\text { Deposition } \\
\text { (kg N/ha) }\end{array}$} & \multirow{2}{*}{$\begin{array}{l}\text { Absolute } \\
\text { difference } \\
\text { (kg N/ha) }\end{array}$} & \multirow{2}{*}{$\begin{array}{c}\text { Mean } \\
\text { deposition } \\
\text { (kg N/ha) }\end{array}$} & \multirow{2}{*}{$\begin{array}{c}\text { Deposition } \\
\text { standard deviation } \\
\text { (kg N/ha) }\end{array}$} & \multirow{2}{*}{$\begin{array}{c}\text { Relative } \\
\text { standard deviation } \\
\text { (percent) }\end{array}$} \\
\hline & C089 & C098 & & & & \\
\hline 2010 & 2.97 & 2.93 & 0.04 & 2.95 & 0.028 & 1.0 \\
\hline 2011 & 2.93 & 3.49 & 0.56 & 3.21 & 0.396 & 12.3 \\
\hline 2012 & 2.84 & 2.61 & 0.23 & 2.72 & 0.163 & 6.0 \\
\hline 2013 & 4.89 & 4.33 & 0.56 & 4.61 & 0.396 & 8.6 \\
\hline \multirow[t]{3}{*}{2014} & 2.99 & 3.00 & 0.01 & 3.00 & 0.007 & 0.2 \\
\hline & & & & & $R S D_{\text {Avg }}$ & 5.6 \\
\hline & & & & & MAD (kg N/ha) & 0.23 \\
\hline
\end{tabular}


Table 7. Calculated confidence limits for inorganic nitrogen deposition measurements at National Atmospheric Deposition Program site C098, Loch Vale, Rocky Mountain National Park, water years 2010-14.

$\left[\mathrm{N}_{\text {inorg }}\right.$, inorganic nitrogen; $\mathrm{kg} \mathrm{N} / \mathrm{ha}$, kilograms of inorganic nitrogen per hectare]

\begin{tabular}{|c|c|c|c|}
\hline Year & $\begin{array}{c}N_{\text {inorg }} \text { deposition } \\
\text { measurement and goals } \\
(\mathrm{kg} \mathrm{N} / \mathrm{ha})\end{array}$ & $\begin{array}{c}90 \% \text { Lower confidence limit } \\
\text { (value is exceeded) }{ }^{1} \\
\text { (kg N/ha) }\end{array}$ & $\begin{array}{c}\text { 90\% Upper confidence limit } \\
\text { (value is not exceeded) }^{1} \\
\text { (kg N/ha) }\end{array}$ \\
\hline 2006 & ${ }^{2} 3.0$ & 2.8 & 3.2 \\
\hline 2012 & 2.7 & 2.5 & 2.9 \\
\hline 2017 & 2.4 & 2.2 & 2.6 \\
\hline 2022 & 2.1 & 1.9 & 2.3 \\
\hline 2027 & 1.8 & 1.7 & 1.9 \\
\hline 2032 & 1.5 & 1.4 & 1.6 \\
\hline
\end{tabular}

${ }^{1}$ One-tailed estimate at $\alpha=0.10$ significance level.

${ }^{2}$ Measured for calendar year 2006.

\section{Summary and Conclusions}

Measurements of precipitation depths and wet-deposition sample volumes and concentrations were conducted at colocated National Atmospheric Deposition Program/National Trends Network (NADP/NTN) monitoring sites CO89 and CO98 at Rocky Mountain National Park, Colorado, during water years 2010-14. The CO98 data met required NADP completeness criteria for the first time in 29 years of operation in 2011 and then again in 2012, and the CO89 data met the criteria in 2012; however, results are still valid and useful for estimation of annual deposition even in years when current completeness criteria are not met.

Median weekly relative precipitation-depth differences were small, ranging from 0 to 0.25 millimeter during the September 29, 2009-September 30, 2014 study period. Median weekly absolute percent differences in sample volume ranged from 5 to 10 percent. Median relative concentration differences for weekly ammonium $\left(\mathrm{NH}_{4}^{+}\right)$and nitrate $\left(\mathrm{NO}_{3}^{-}\right)$ concentrations were near the method detection limits (MDLs) of the Central Analytical Laboratory (CAL), which ranged from 0.005 to 0.016 milligram per liter $(\mathrm{mg} / \mathrm{L})$ for $\mathrm{NH}_{4}^{+}$and from 0.004 to $0.025 \mathrm{mg} / \mathrm{L}$ for $\mathrm{NO}_{3}^{-}$during 2010-13; however, the median $\mathrm{NO}_{3}^{-}$concentration difference $(0.056 \mathrm{mg} / \mathrm{L})$ in water year 2014 was more than two times the CAL's MDL for 2013. More variability in precipitation-depth and samplevolume differences was observed for weeks with snow only than for weeks with rain only. Absolute percent differences for all parameters were similar to previously published values for 41 colocated sites located throughout the NTN.

Water-year precipitation-weighted mean concentrations (PWMCs) for $\mathrm{NO}_{3}{ }^{-}$or inorganic nitrogen $\left(\mathrm{N}_{\text {inorg }}\right)$ were higher, and total annual deposition amounts were greater for site CO98 than for site CO89 for every water year except 2012 and 2013; however, data for water year 2013 were affected by a major flood that closed the park and prevented access for routine sample collection. Absolute percent differences for $\mathrm{NH}_{4}^{+}$, $\mathrm{NO}_{3}^{-}$, and $\mathrm{N}_{\text {inorg }}$ PWMCs ranged from 0.0 to 25.7 percent. Absolute percent differences for $\mathrm{NH}_{4}^{+}, \mathrm{NO}_{3}^{-}$, and $\mathrm{N}_{\text {inorg }}$ wateryear deposition ranged from 0.3 to 24.5 percent.

The average relative standard deviation for the five replicate measurements of annual $\mathrm{N}_{\text {inorg }}$ deposition was 5.6 percent. Confidence limits for measurement of $\mathrm{N}_{\text {inorg }}$ deposition goals along the glidepath of the Rocky Mountain National Park Nitrogen Deposition Reduction Plan (NDRP) were calculated. Estimated 90-percent $(\alpha=0.10)$ and 95-percent $(\alpha=0.05)$ confidence limits for the inorganic nitrogen critical load of 1.5 kilograms per hectare ( $\mathrm{kg} \mathrm{N} / \mathrm{ha})$ are $1.4 \mathrm{~kg} \mathrm{~N} / \mathrm{ha}$ and $1.6 \mathrm{~kg} \mathrm{~N} / \mathrm{ha}$ for the upper and lower limits, respectively.

Results presented herein are for water years 2010-14 because data for the CO89 site were collected for 5 complete water years, not calendar years. Analysis by water years allowed for better comparison of results for 2013, when the monitoring data were relatively incomplete. The NDRP presents results on a calendar-year basis. Therefore, this assessment of data quality and variability is intended for general interpretation of monitoring data for the NDRP. 


\section{References}

Baron, J.S., 2006, Hindcasting nitrogen deposition to determine an ecological critical load: Ecological Applications, v. 16 , no. 2 , p. 433-439.

Baron, J.S., and Mast, M.A., 1992, Regional characterization and setting for the Loch Vale watershed study, in Baron, J.S., ed., Biogeochemistry of a subalpine ecosystem: New York, Springer, p. 12-27. [Also available at http:// link.springer.com/chapter/10.1007/978-1-4612-2788-5_2.]

Dossett, S.R., and Bowersox, V.C., 1999, National Trends Network site operation manual: Champaign, Ill., National Atmospheric Deposition Program Office, Illinois State Water Survey, NADP Manual 1999-01, accessed August 30, 2013, at http://nadp.isws.illinois.edu/lib/manuals.aspx.

Fassnacht, S.R., 2004, Estimating alter-shielded gauge snowfall undercatch, snowpack sublimation, and blowing snow transport at six sites in the conterminous United States, in Eastern Snow Conference, 61st, Portland, Maine, June 9-11, 2004, Proceedings: Eastern Snow Conference, p. 15-26.

Helsel, D.R., 2012, Statistics for censored environmental data using Minitab and R (2d ed.): Hoboken, N.J., John Wiley and Sons, $344 \mathrm{p}$.

Hollander, M., and Wolfe, D.A., 1999, Nonparametric statistical methods ( $2 \mathrm{~d}$ ed.): New York, John Wiley \& Sons, 787 p.

Morris, K., Mast, A., Clow, D., Wetherbee, G., Baron, J., Taipale, C., Blett, T., Gay, D., and Bowker, D., 2015, 2013 Monitoring and tracking wet nitrogen deposition at Rocky Mountain National Park: U.S. Department of the Interior, National Park Service, Natural Resources Report NPS/ NRSS/ARD/NRR-2015/997, 42 p.

National Atmospheric Deposition Program, 2014, NADP siting criteria diagrams, appendix A of NADP site selection and installation manual (ver. 1.9): Champaign, Ill., National Atmospheric Deposition Program Office, Illinois State Water Survey, p. 13-16, accessed May 20, 2016, at http:// nadp.sws.uiuc.edu/lib/manuals/NADP_Site_Selection_and Installation_Manual_2014_11.pdf.

National Atmospheric Deposition Program, 2016a, NTN data retrieval options: Champaign, Ill., National Atmospheric Deposition Program Office Web site, Illinois State Water Survey, accessed March 31, 2016, at http:// nadp.isws.illinois.edu/NTN/ntnData.aspx.

National Atmospheric Deposition Program, 2016b, Raingage preliminary data, subject to revision: Champaign, Ill., National Atmospheric Deposition Program Office Web site, Illinois State Water Survey, accessed January 16, 2016, at http://nadp.sws.uiuc.edu/siteOps/ppt/default.aspx.
National Park Service, 2007, Rocky Mountain National Park Nitrogen Deposition Reduction Plan: National Park Service, 86 p., accessed April 24, 2015, at https://www.colorado. gov/pacific/sites/default/files/AP_PO_Nitrogen-DepositionReduction-Plan-NDRP.pdf.

National Park Service, 2011, 2009 Monitoring and tracking wet nitrogen deposition at Rocky Mountain National Park: U.S. Department of the Interior, National Park Service, Natural Resources Report NPS/NRSS/ARD/NRR-2011/442, 21 p., accessed March 31, 2016 at https://www.nature.nps.gov/ air/pubs/pdf/rmnp-trends/rmnp-trends_2009.pdf.

Rhodes, M.F., Douglas, L., Koch, C., and Dombek, T., 2011, National Trends Network, sample evaporation, in NADP at the nexus - Cross system connections, 2011 Annual meeting and scientific symposium, Providence, R.I., October 25-28, 2011, Proceedings: National Atmospheric Deposition Program, p. 92.

Weiss, L.L., 1961, Relative catches of snow in shielded and unshielded gages at different wind speeds: Monthly Weather Review, p. 397-400.

Wetherbee, G.A., Latysh, N.E., and Gordon, J.D., 2005, Spatial and temporal variability of the overall error of National Atmospheric Deposition Program measurements determined by the USGS collocated-sampler program, water years 1989-2001: Environmental Pollution, v. 135, p. 407-418.

Yang, D., Goodison, B.E., and Metaclfe, J.R., 1998, Accuracy of NWS 80 standard nonrecording precipitation gaugeResults and application of WMO intercomparison: Journal of Atmospheric and Oceanic Technology, v. 15, no. 1, p. 54-68.

Publishing support provided by: Denver Publishing Service Center

For more information concerning this publication, contact: Chief, USGS Branch of Quality Systems

Box 25046, Mail Stop 401

Denver, CO 80225

(303) 236-1835

Or visit the Branch of Quality Systems Web site at: http://bqs.usgs.gov/ 
Appendix 1 
Table 1-1. Wet-deposition sample analysis data for colocated sites C089 and C098, water years 2010-14.

[Date on, start of weekly sample collection; Date off, end of weekly sample collection; Ca, calcium; $\mathrm{Mg}$, magnesium; $\mathrm{K}$, potassium; $\mathrm{Na}$, sodium; $\mathrm{NH}_{4}$, ammonium; $\mathrm{NO}_{3}$, nitrate; $\mathrm{N}$, inorganic nitrogen; $\mathrm{Cl}$, chloride; $\mathrm{SO}_{4}$, sulfate; $\mathrm{pH}$, negative log of hydrogen-ion molarity; Cond, specific conductance in microSeimens per centimeter; Svol, sample volume in milliliters; RG ppt, rain gage precipitation depth in millimeters; Sub ppt, sample volume converted to depth substituted for missing weekly RG ppt. Lab types: W, sufficient volume for analysis; WD, dilution necessary to obtain volume for analysis; D, valid dry week; T, valid trace sample with insufficient volume for analysis. Inval codes: b, bulk sample (collector was open continuously); c, contaminated; d, debris; e, extended sampling period greater than 8 days; h, handling protocol problems; m, missing data; u, undefined; v, inadequate volume for analysis; z, site operation problems; *, no Inval code assigned. QR (Quality Rating) codes: A, highest quality rating; $\mathrm{B}$, valid with minor problems; C, invalid. Concentrations in milligrams per liter. Valid dry week samples have no chemical data and have QR code of A. --, no data]

\begin{tabular}{|c|c|c|c|c|c|c|c|c|c|c|c|c|c|c|c|c|c|c|c|}
\hline Site & Date on & Date off & $\mathrm{Ca}$ & Mg & $\mathbf{K}$ & $\mathrm{Na}$ & $\mathrm{NH}_{4}$ & $\mathrm{NO}_{3}$ & $\mathbf{N}$ & Cl & $\mathrm{SO}_{4}$ & $\mathrm{pH}$ & Cond & Svol & $\begin{array}{l}\text { RG } \\
\text { ppt }\end{array}$ & $\begin{array}{l}\text { Sub } \\
\text { ppt }\end{array}$ & $\begin{array}{l}\text { Lab } \\
\text { type }\end{array}$ & $\begin{array}{l}\text { Inval } \\
\text { codes }\end{array}$ & $\begin{array}{c}\mathrm{OR} \\
\text { code }\end{array}$ \\
\hline CO89 & $9 / 29 / 2009$ & $10 / 6 / 2009$ & 1.714 & 0.127 & 0.091 & 0.11 & 0.245 & 0.788 & 0.369 & 0.145 & 0.657 & 7.33 & 13 & 973.5 & 27.18 & 27.18 & $\mathrm{~W}$ & $*$ & B \\
\hline CO89 & $10 / 6 / 2009$ & $10 / 13 / 2009$ & 0.24 & 0.038 & 0.021 & 0.118 & 0.207 & 0.946 & 0.375 & 0.169 & 0.581 & 5.35 & 6.8 & 423.2 & 27.18 & 27.18 & W & $*$ & B \\
\hline CO89 & $10 / 13 / 2009$ & $10 / 20 / 2009$ & 0.063 & 0.008 & 0.011 & 0.022 & 0.069 & 0.423 & 0.149 & 0.032 & 0.323 & 5.14 & 4.8 & 954.5 & 17.53 & 17.53 & W & $*$ & B \\
\hline CO89 & $10 / 20 / 2009$ & $10 / 27 / 2009$ & 0.305 & 0.029 & 0.019 & 0.034 & 0.202 & 1.038 & 0.392 & 0.057 & 0.444 & 5.6 & 5.7 & 656.9 & 21.08 & 21.08 & W & $*$ & B \\
\hline CO89 & $10 / 27 / 2009$ & $11 / 3 / 2009$ & 0.061 & 0.005 & 0.004 & 0.005 & 0.018 & 0.242 & 0.069 & 0.013 & 0.078 & 5.47 & 2.2 & 1334.3 & 42.16 & 42.16 & W & $*$ & B \\
\hline CO89 & $11 / 3 / 2009$ & $11 / 10 / 2009$ & -- & -- & -- & -- & -- & -- & -- & -- & -- & -- & -- & 0 & 0.25 & 0.25 & $\mathrm{D}$ & $\mathrm{v}$ & $\mathrm{C}$ \\
\hline CO89 & $11 / 10 / 2009$ & $11 / 17 / 2009$ & 0.243 & 0.018 & 0.015 & 0.02 & 0.187 & 0.645 & 0.291 & 0.042 & 0.425 & 5.75 & 4.3 & 887.8 & 24.64 & 24.64 & W & $*$ & A \\
\hline CO89 & $11 / 17 / 2009$ & $11 / 24 / 2009$ & 0.179 & 0.016 & 0.014 & 0.082 & 0.072 & 0.689 & 0.212 & 0.056 & 0.253 & 5.55 & 4.2 & 318 & 16.26 & 16.26 & W & $*$ & B \\
\hline CO89 & $11 / 24 / 2009$ & $12 / 1 / 2009$ & -- & -- & -- & -- & -- & -- & -- & -- & -- & -- & -- & 0 & 0 & 0 & $\mathrm{D}$ & $*$ & A \\
\hline CO89 & $12 / 1 / 2009$ & $12 / 8 / 2009$ & 0.07 & 0.007 & 0.005 & 0.024 & 0.074 & 0.517 & 0.174 & 0.027 & 0.09 & 5.45 & 3.1 & 1327.1 & 32.77 & 32.77 & W & $\mathrm{u}$ & $\mathrm{C}$ \\
\hline CO89 & $12 / 8 / 2009$ & $12 / 15 / 2009$ & -- & -- & -- & -- & -- & -- & -- & -- & -- & -- & -- & 1.6 & 60.71 & 60.71 & $\mathrm{D}$ & $\mathrm{vb}$ & $\mathrm{C}$ \\
\hline CO89 & $12 / 15 / 2009$ & $12 / 22 / 2009$ & -- & -- & -- & -- & -- & -- & -- & -- & -- & -- & -- & 0.1 & 5.84 & 5.84 & $\mathrm{D}$ & $\mathrm{v}$ & $\mathrm{C}$ \\
\hline CO89 & $12 / 22 / 2009$ & $12 / 29 / 2009$ & 0.046 & 0.007 & 0.038 & 0.012 & 0.099 & 0.611 & 0.215 & 0.024 & 0.186 & 5.27 & 4.7 & 314.3 & 29.21 & 29.21 & $\mathrm{~W}$ & $\mathrm{u}$ & $\mathrm{C}$ \\
\hline CO89 & $12 / 29 / 2009$ & $1 / 5 / 2010$ & 0.062 & 0.005 & 0.003 & 0.005 & 0.026 & 0.548 & 0.144 & 0.045 & 0.188 & 5.04 & 5.9 & 28 & 22.35 & 22.35 & WD & $\mathrm{u}$ & $\mathrm{C}$ \\
\hline CO89 & $1 / 5 / 2010$ & $1 / 12 / 2010$ & -- & -- & -- & -- & -- & -- & -- & -- & -- & -- & -- & 0 & 15.24 & 15.24 & $\mathrm{D}$ & $\mathrm{vb}$ & $\mathrm{C}$ \\
\hline CO89 & $1 / 12 / 2010$ & $1 / 19 / 2010$ & -- & -- & -- & -- & -- & -- & -- & -- & -- & -- & -- & 0 & 0.25 & 0.25 & $\mathrm{D}$ & $\mathrm{v}$ & $\mathrm{C}$ \\
\hline CO89 & $1 / 19 / 2010$ & $1 / 26 / 2010$ & 0.046 & 0.005 & 0.02 & 0.027 & 0.07 & 0.213 & 0.103 & 0.059 & 0.075 & 5.35 & 2.7 & 50.8 & 22.35 & 22.35 & WD & $*$ & B \\
\hline CO89 & $1 / 26 / 2010$ & $2 / 2 / 2010$ & 0.032 & 0.002 & 0.003 & 0.009 & 0.138 & 0.871 & 0.304 & 0.026 & 0.088 & 5.17 & 5.4 & 368.8 & 13.46 & 13.46 & W & $*$ & A \\
\hline CO89 & $2 / 2 / 2010$ & 2/9/2010 & 0.054 & 0.005 & 0.004 & 0.019 & 0.205 & 1.267 & 0.446 & 0.037 & 0.381 & 4.72 & 10 & 187.1 & 9.65 & 9.65 & W & $*$ & B \\
\hline CO89 & $2 / 9 / 2010$ & $2 / 16 / 2010$ & 0.097 & 0.008 & 0.006 & 0.023 & 0.094 & 0.422 & 0.168 & 0.029 & 0.257 & 5.44 & 3.6 & 73.3 & 27.43 & 27.43 & W & $*$ & B \\
\hline CO89 & $2 / 16 / 2010$ & $2 / 23 / 2010$ & 0.082 & 0.009 & 0.011 & 0.025 & 0.067 & 0.418 & 0.147 & 0.035 & 0.165 & 5.46 & 3.8 & 1484.7 & 37.34 & 37.34 & W & $*$ & B \\
\hline CO89 & $2 / 23 / 2010$ & $3 / 2 / 2010$ & 0.034 & 0.003 & 0.004 & 0.008 & 0.042 & 1.492 & 0.37 & 0.06 & 0.095 & 4.7 & 11.2 & 376.3 & 8.64 & 8.64 & W & $*$ & A \\
\hline CO89 & $3 / 2 / 2010$ & $3 / 9 / 2010$ & 0.05 & 0.005 & 0.003 & 0.013 & 0.082 & 0.332 & 0.139 & 0.031 & 0.28 & 5.19 & 4 & 116.3 & 23.88 & 23.88 & W & $*$ & A \\
\hline CO89 & $3 / 9 / 2010$ & $3 / 16 / 2010$ & 0.09 & 0.008 & 0.006 & 0.012 & 0.866 & 1.194 & 0.943 & 0.023 & 0.813 & 6.13 & 7.9 & 359.2 & 11.43 & 11.43 & W & $*$ & A \\
\hline CO89 & $3 / 16 / 2010$ & $3 / 23 / 2010$ & 0.102 & 0.01 & 0.006 & 0.017 & 0.112 & 0.566 & 0.215 & 0.025 & 0.135 & 5.5 & 3.2 & 1222.3 & 31.75 & 31.75 & W & $*$ & B \\
\hline CO89 & $3 / 23 / 2010$ & $3 / 30 / 2010$ & 0.072 & 0.007 & 0.004 & 0.02 & 0.162 & 0.243 & 0.181 & 0.022 & 0.13 & 5.97 & 2.4 & 1325.2 & 30.48 & 30.48 & W & $*$ & B \\
\hline CO89 & $3 / 30 / 2010$ & $4 / 6 / 2010$ & 1.168 & 0.068 & 0.04 & 0.036 & 0.098 & 0.314 & 0.147 & 0.036 & 0.337 & 6.75 & 8.4 & 1113.6 & 82.8 & 82.8 & W & $*$ & B \\
\hline CO89 & $4 / 6 / 2010$ & $4 / 13 / 2010$ & 3.614 & 0.176 & 0.108 & 0.154 & 0.186 & 0.943 & 0.358 & 0.135 & 1.102 & 7.34 & 23.5 & 265.8 & 18.54 & 18.54 & W & $*$ & B \\
\hline CO89 & $4 / 13 / 2010$ & $4 / 20 / 2010$ & 0.162 & 0.021 & 0.009 & 0.022 & 0.194 & 0.859 & 0.345 & 0.043 & 0.444 & 4.9 & 8.9 & 184.3 & 5.33 & 5.33 & W & $*$ & A \\
\hline CO89 & $4 / 20 / 2010$ & $4 / 27 / 2010$ & 0.1 & 0.013 & 0.006 & 0.019 & 0.103 & 0.319 & 0.152 & 0.024 & 0.236 & 5.63 & 3 & 2465.5 & 68.83 & 68.83 & W & $*$ & B \\
\hline CO89 & $5 / 4 / 2010$ & $5 / 11 / 2010$ & 1.446 & 0.135 & 0.074 & 0.193 & 0.379 & 1.688 & 0.676 & 0.153 & 1.186 & 6.42 & 14.2 & 728.7 & 25.4 & 25.4 & W & $*$ & B \\
\hline CO89 & $5 / 11 / 2010$ & $5 / 18 / 2010$ & 0.874 & 0.046 & 0.048 & 0.041 & 0.08 & 0.412 & 0.155 & 0.036 & 0.32 & 6.69 & 6.6 & 3458.6 & 74.42 & 74.42 & W & $*$ & B \\
\hline CO89 & $6 / 8 / 2010$ & $6 / 15 / 2010$ & 0.179 & 0.017 & 0.023 & 0.031 & 0.131 & 0.408 & 0.194 & 0.053 & 0.265 & 5.84 & 3.7 & 3436.8 & 54.86 & 54.86 & W & $*$ & B \\
\hline
\end{tabular}


Table 1-1. Wet-deposition sample analysis data for colocated sites C089 and C098, water years 2010-14.-Continued

[Date on, start of weekly sample collection; Date off, end of weekly sample collection; $\mathrm{Ca}$, calcium; $\mathrm{Mg}$, magnesium; $\mathrm{K}$, potassium; $\mathrm{Na}$, sodium; $\mathrm{NH}_{4}$, ammonium; $\mathrm{NO}_{3}$, nitrate; $\mathrm{N}$, inorganic nitrogen; $\mathrm{Cl}$, chloride; $\mathrm{SO}_{4}$, sulfate; $\mathrm{pH}$, negative log of hydrogen-ion molarity; Cond, specific conductance in microSeimens per centimeter; Svol, sample volume in milliliters; RG ppt, rain gage precipitation depth in millimeters; Sub ppt, sample volume converted to depth substituted for missing weekly RG ppt. Lab types: W, sufficient volume for analysis; WD, dilution necessary to obtain volume for analysis; D, valid dry week; T, valid trace sample with insufficient volume for analysis. Inval codes: b, bulk sample (collector was open continuously); c, contaminated; d, debris; e, extended sampling period greater than 8 days; h, handling protocol problems; m, missing data; u, undefined; v, inadequate volume for analysis; z, site operation problems; *, no Inval code assigned. QR (Quality Rating) codes: A, highest quality rating;

B, valid with minor problems; C, invalid. Concentrations in milligrams per liter. Valid dry week samples have no chemical data and have QR code of A. --, no data]

\begin{tabular}{|c|c|c|c|c|c|c|c|c|c|c|c|c|c|c|c|c|c|c|c|}
\hline Site & Date on & Date off & Ca & Mg & K & $\mathrm{Na}$ & $\mathrm{NH}_{4}$ & $\mathrm{NO}_{3}$ & $\mathbf{N}$ & Cl & $\mathrm{SO}_{4}$ & $\mathrm{pH}$ & Cond & Svol & $\begin{array}{l}\text { RG } \\
\text { ppt }\end{array}$ & $\begin{array}{l}\text { Sub } \\
\text { ppt }\end{array}$ & $\begin{array}{l}\text { Lab } \\
\text { type }\end{array}$ & $\begin{array}{l}\text { Inval } \\
\text { codes }\end{array}$ & $\begin{array}{c}\text { OR } \\
\text { code }\end{array}$ \\
\hline CO89 & $6 / 29 / 2010$ & $7 / 6 / 2010$ & 0.244 & 0.024 & 0.036 & 0.014 & 0.123 & 1.348 & 0.4 & 0.064 & 0.52 & 4.65 & 11.5 & 589.4 & 9.14 & 9.14 & $\mathrm{~W}$ & $*$ & B \\
\hline CO89 & $7 / 6 / 2010$ & $7 / 13 / 2010$ & 0.149 & 0.022 & 0.026 & 0.065 & 0.193 & 0.764 & 0.323 & 0.105 & 0.423 & 5.15 & 6.1 & 1965.7 & 31.5 & 31.5 & W & $*$ & B \\
\hline CO89 & $7 / 13 / 2010$ & $7 / 20 / 2010$ & 0.373 & 0.042 & 0.04 & 0.066 & 0.421 & 1.209 & 0.601 & 0.124 & 0.646 & 5.83 & 7.4 & 790.6 & 11.68 & 11.68 & W & $*$ & B \\
\hline CO89 & $7 / 20 / 2010$ & $7 / 27 / 2010$ & 0.24 & 0.027 & 0.03 & 0.04 & 0.252 & 1.061 & 0.436 & 0.071 & 0.438 & 5.27 & 6.7 & -- & 12.7 & 12.7 & W & $*$ & B \\
\hline CO89 & $7 / 27 / 2010$ & $8 / 3 / 2010$ & 0.06 & 0.007 & 0.009 & 0.011 & 0.172 & 0.628 & 0.276 & 0.028 & 0.281 & 5.04 & 5.8 & 4709 & 71.12 & 71.12 & W & $*$ & B \\
\hline CO89 & $8 / 3 / 2010$ & $8 / 10 / 2010$ & 0.05 & 0.006 & 0.01 & 0.014 & 0.194 & 0.779 & 0.327 & 0.043 & 0.343 & 4.96 & 7 & -- & 32.26 & 32.26 & W & $*$ & B \\
\hline CO89 & $8 / 10 / 2010$ & $8 / 17 / 2010$ & 0.037 & 0.005 & 0.01 & 0.013 & 0.03 & 0.198 & 0.068 & 0.023 & 0.217 & 5.17 & 3.4 & 481.7 & 7.37 & 7.37 & W & $*$ & B \\
\hline CO89 & $8 / 17 / 2010$ & $8 / 24 / 2010$ & 0.082 & 0.01 & 0.01 & 0.016 & 0.092 & 0.406 & 0.163 & 0.03 & 0.222 & 5.31 & 3.6 & 483.2 & 8.89 & 8.89 & W & $*$ & B \\
\hline CO89 & $8 / 24 / 2010$ & $8 / 31 / 2010$ & 0.088 & 0.009 & 0.009 & 0.009 & 0.092 & 0.61 & 0.209 & 0.033 & 0.31 & 5.07 & 5.5 & 388.8 & 5.84 & 5.84 & $\mathrm{~W}$ & $*$ & B \\
\hline CO89 & 9/7/2010 & $9 / 14 / 2010$ & 0.024 & 0.003 & 0.003 & 0.007 & 0.067 & 0.21 & 0.1 & 0.019 & 0.133 & 5.34 & 3 & 797.7 & 11.43 & 11.43 & W & $*$ & A \\
\hline CO89 & $9 / 21 / 2010$ & $9 / 28 / 2010$ & 0.076 & 0.008 & 0.007 & 0.02 & 0.076 & 0.422 & 0.154 & 0.037 & 0.199 & 5.4 & 3.7 & 941.7 & 15.49 & 15.49 & W & $*$ & B \\
\hline CO89 & $10 / 5 / 2010$ & $10 / 12 / 2010$ & 0.079 & 0.008 & 0.012 & 0.008 & 0.197 & 0.426 & 0.249 & 0.022 & 0.432 & 5.42 & 4.4 & 1583.3 & 31.5 & 31.5 & W & $*$ & B \\
\hline CO89 & $10 / 12 / 2010$ & $10 / 19 / 2010$ & 0.105 & 0.009 & 0.008 & 0.01 & 0.195 & 0.627 & 0.293 & 0.023 & 0.47 & 5.21 & 5.2 & 818.1 & 14.48 & 14.48 & W & $*$ & A \\
\hline CO89 & $10 / 19 / 2010$ & $10 / 26 / 2010$ & 0.027 & & & & & & 0.1 & & & & & & 0 & & & $*$ & B \\
\hline CO89 & $11 / 9 / 2010$ & $11 / 16 / 2010$ & 0.069 & 0.007 & 0.012 & 0.013 & 0.128 & 1.18 & 0.366 & 0.03 & 0.28 & 4.83 & 7.6 & 185.9 & 37.34 & 37.34 & W & $*$ & A \\
\hline CO89 & $11 / 16 / 2010$ & $11 / 23 / 2010$ & 0.136 & 0.014 & 0.036 & 0.011 & 0.022 & 0.256 & 0.075 & 0.02 & 0.187 & 5.55 & 2.7 & 148.6 & 48.51 & 48.51 & W & $*$ & B \\
\hline CO89 & $11 / 23 / 2010$ & $11 / 30 / 2010$ & 0.091 & 0.009 & 0.029 & 0.034 & 0.038 & 0.347 & 0.108 & 0.06 & 0.12 & 5.33 & 3.1 & 94.7 & 20.57 & 20.57 & W & $*$ & B \\
\hline CO89 & $12 / 14 / 2010$ & $12 / 21 / 2010$ & 0.012 & 0.001 & 0.001 & 0.002 & 0.005 & 0.15 & 0.038 & 0.012 & 0.104 & 5.27 & 2.6 & 785.3 & 122.43 & 122.43 & W & $*$ & B \\
\hline CO89 & $12 / 21 / 2010$ & $12 / 28 / 2010$ & 0.022 & 0.003 & 0.004 & 0.002 & 0.011 & 0.164 & 0.046 & 0.017 & 0.087 & 5.4 & 2.3 & 92 & 17.02 & 17.02 & $\mathrm{~W}$ & $*$ & B \\
\hline CO89 & $12 / 28 / 2010$ & $1 / 4 / 2011$ & 0.059 & 0.005 & 0.011 & 0.004 & 0.086 & 0.676 & 0.22 & 0.016 & 0.184 & 5.15 & 4.9 & 114.2 & 20.57 & 20.57 & $\mathrm{~W}$ & $*$ & B \\
\hline CO89 & $1 / 4 / 2011$ & $1 / 11 / 2011$ & 0.011 & 0.002 & 0.002 & 0.004 & 0.089 & 0.474 & 0.176 & 0.017 & 0.202 & 5.08 & 4.6 & 323 & 24.13 & 24.13 & W & $*$ & B \\
\hline CO89 & $1 / 11 / 2011$ & $1 / 18 / 2011$ & 0.017 & 0.002 & 0.002 & 0.004 & 0.019 & 0.11 & 0.04 & 0.01 & 0.073 & 5.36 & 2.7 & 567.6 & 60.45 & 60.45 & W & $*$ & B \\
\hline CO89 & $1 / 18 / 2011$ & $1 / 25 / 2011$ & 0.023 & 0.003 & 0.004 & 0.002 & 0.015 & 0.19 & & & & 5.25 & 3 & & & & W & $*$ & A \\
\hline CO89 & $1 / 25 / 2011$ & $2 / 2 / 2011$ & 0.036 & 0.004 & 0.004 & 0.01 & 0.083 & 0.668 & 0.215 & 0.024 & 0.225 & 4.94 & 5.8 & 149 & 5.59 & 5.59 & W & $*$ & A \\
\hline CO89 & $2 / 2 / 2011$ & $2 / 8 / 2011$ & 0.034 & 0.003 & 0.002 & 0.029 & 0.034 & 0.19 & 0.069 & 0.03 & 0.13 & 5.39 & 2.5 & 1188.4 & 0 & 17.5 & $\mathrm{~W}$ & $*$ & B \\
\hline CO89 & 2/8/2011 & $2 / 15 / 2011$ & -- & -- & -- & -- & -- & -- & -- & -- & -- & -- & -- & 1.5 & 11.94 & 11.94 & $\mathrm{~T}$ & $\mathrm{v}$ & $\mathrm{C}$ \\
\hline CO89 & $2 / 15 / 2011$ & $2 / 22 / 2011$ & 0.04 & 0.004 & 0.004 & 0.007 & 0.035 & 0.139 & 0.059 & 0.01 & 0.071 & 5.53 & 2 & 538.2 & 37.85 & 37.85 & $\mathrm{~W}$ & $*$ & B \\
\hline CO89 & $2 / 22 / 2011$ & $3 / 1 / 2011$ & 0.155 & 0.015 & 0.012 & 0.028 & 0.125 & 0.751 & 0.267 & 0.048 & 0.138 & 5.41 & 3.9 & 545.5 & 67.31 & 67.31 & W & $*$ & B \\
\hline CO89 & $3 / 1 / 2011$ & $3 / 8 / 2011$ & 0.087 & 0.014 & 0.01 & 0.018 & 0.084 & 0.449 & 0.167 & 0.028 & 0.303 & 5.28 & 4.2 & 507.7 & 28.19 & 28.19 & W & $*$ & A \\
\hline CO89 & $3 / 8 / 2011$ & $3 / 15 / 2011$ & 0.1 & 0.012 & 0.007 & 0.025 & 0.127 & 0.553 & 0.224 & 0.026 & & 5.45 & 3.4 & & & 24.64 & W & $*$ & B \\
\hline CO89 & $3 / 15 / 2011$ & $3 / 22 / 2011$ & 0.638 & 0.046 & 0.038 & 0.059 & 0.064 & 0.408 & 0.142 & 0.043 & 0.357 & 6.47 & 4.9 & 1220.8 & 42.93 & 42.93 & W & $*$ & B \\
\hline CO89 & $3 / 22 / 2011$ & $3 / 29 / 2011$ & 0.129 & 0.016 & 0.008 & 0.021 & 0.053 & 0.352 & 0.121 & 0.029 & 0.249 & 5.49 & 3.1 & 938.1 & 49.78 & 49.78 & W & $*$ & B \\
\hline CO89 & $3 / 29 / 2011$ & $4 / 5 / 2011$ & 0.356 & 0.037 & 0.047 & 0.026 & 0.147 & 0.653 & 0.262 & 0.059 & 0.399 & 5.96 & 4.5 & 408 & 60.2 & 60.2 & W & $*$ & B \\
\hline
\end{tabular}


[Date on, start of weekly sample collection; Date off, end of weekly sample collection; Ca, calcium; $\mathrm{Mg}$, magnesium; $\mathrm{K}$, potassium; $\mathrm{Na}$, sodium; $\mathrm{NH}_{4}$, ammonium; $\mathrm{NO}_{3}$, nitrate; $\mathrm{N}$, inorganic nitrogen; $\mathrm{Cl}$, chloride; $\mathrm{SO}_{4}$, sulfate; $\mathrm{pH}$, negative log of hydrogen-ion molarity; Cond, specific conductance in microSeimens per centimeter; Svol, sample volume in milliliters; RG ppt, rain gage precipitation depth in millimeters; Sub ppt, sample volume converted to depth substituted for missing weekly RG ppt. Lab types: W, sufficient volume for analysis; WD, dilution necessary to obtain volume for analysis; D, valid dry week; T, valid trace sample with insufficient volume for analysis. Inval codes: b, bulk sample (collector was open continuously); c, contaminated; d, debris; e, extended sampling period greater than 8 days; h, handling protocol problems; m, missing data; u, undefined; v, inadequate volume for analysis; z, site operation problems; *, no Inval code assigned. QR (Quality Rating) codes: A, highest quality rating; B, valid with minor problems; C, invalid. Concentrations in milligrams per liter. Valid dry week samples have no chemical data and have QR code of A. --, no data]

\begin{tabular}{|c|c|c|c|c|c|c|c|c|c|c|c|c|c|c|c|c|c|c|c|}
\hline Site & Date on & Date off & $\mathrm{Ca}$ & Mg & K & $\mathrm{Na}$ & $\mathrm{NH}_{4}$ & $\mathrm{NO}_{3}$ & $\mathbf{N}$ & Cl & $\mathrm{SO}_{4}$ & $\mathrm{pH}$ & Cond & Svol & $\begin{array}{l}\text { RG } \\
\text { ppt }\end{array}$ & $\begin{array}{l}\text { Sub } \\
\text { ppt }\end{array}$ & $\begin{array}{l}\text { Lab } \\
\text { type }\end{array}$ & $\begin{array}{l}\text { Inval } \\
\text { codes }\end{array}$ & $\begin{array}{c}\text { OR } \\
\text { code }\end{array}$ \\
\hline CO89 & $4 / 5 / 2011$ & $4 / 12 / 2011$ & 0.133 & 0.015 & 0.023 & 0.033 & 0.122 & 0.395 & 0.184 & 0.05 & 0.336 & 5.54 & 3.6 & 528.6 & 40.64 & 40.64 & $\mathrm{~W}$ & $*$ & $\mathrm{~A}$ \\
\hline CO89 & $4 / 12 / 2011$ & $4 / 19 / 2011$ & 0.14 & 0.017 & 0.019 & 0.018 & 0.222 & 0.553 & 0.298 & 0.03 & 0.423 & 5.58 & 4.3 & 2909.1 & 0 & 42.85 & W & $*$ & B \\
\hline CO89 & $4 / 19 / 2011$ & $4 / 26 / 2011$ & 0.168 & 0.018 & 0.013 & 0.018 & 0.157 & 0.439 & 0.221 & 0.024 & 0.399 & 5.87 & 3.7 & 3623.9 & 0 & 53.38 & W & $*$ & B \\
\hline CO89 & $4 / 26 / 2011$ & $5 / 3 / 2011$ & 0.126 & 0.014 & 0.009 & 0.033 & 0.107 & 0.361 & 0.165 & 0.04 & 0.264 & 5.6 & 3 & 803.3 & 16.51 & 16.51 & W & $*$ & A \\
\hline CO89 & $5 / 3 / 2011$ & $5 / 10 / 2011$ & 0.789 & 0.09 & 0.024 & 0.084 & 0.193 & 1.407 & 0.468 & 0.102 & 0.791 & 6.22 & 8.3 & 92.5 & 33.02 & 33.02 & W & * & B \\
\hline CO89 & $5 / 10 / 2011$ & $5 / 17 / 2011$ & 0.229 & 0.033 & 0.014 & 0.034 & 0.175 & 0.277 & 0.199 & 0.046 & 0.325 & 6.05 & 3.6 & 2560.5 & 55.63 & 55.63 & W & $*$ & $\mathrm{~B}$ \\
\hline CO89 & $5 / 17 / 2011$ & $5 / 24 / 2011$ & -- & -- & -- & -- & -- & -- & -- & -- & -- & -- & -- & 3448.5 & 0 & 50.8 & W & $\mathrm{u}$ & $\mathrm{C}$ \\
\hline CO89 & $5 / 24 / 2011$ & $5 / 31 / 2011$ & -- & -- & -- & -- & -- & -- & -- & -- & -- & -- & -- & 1338.5 & 82.55 & 82.55 & W & $\mathrm{c}$ & $\mathrm{C}$ \\
\hline CO89 & $5 / 31 / 2011$ & $6 / 7 / 2011$ & -- & -- & -- & -- & -- & -- & -- & -- & -- & -- & -- & 0.5 & 0 & 0 & $\mathrm{~T}$ & $*$ & A \\
\hline CO89 & $6 / 7 / 2011$ & $6 / 14 / 2011$ & 1.264 & 0.111 & 0.091 & 0.13 & 0.15 & 2.054 & 0.581 & 0.211 & 1.179 & 5.96 & 11.9 & 70 & 1.52 & 1.52 & W & $*$ & B \\
\hline CO89 & $6 / 14 / 2011$ & $6 / 21 / 2011$ & 0.207 & 0.023 & 0.035 & 0.03 & 0.18 & 0.657 & 0.288 & 0.056 & 0.518 & 5.45 & 5.1 & 2768 & 44.45 & 44.45 & $\mathrm{~W}$ & $*$ & B \\
\hline CO89 & $6 / 21 / 2011$ & $6 / 28 / 2011$ & 0.935 & 0.114 & 0.148 & 0.102 & 0.016 & 0.314 & 0.083 & 0.138 & 0.927 & 5.23 & 10.6 & 25 & 0.25 & 0.25 & WD & $*$ & B \\
\hline CO89 & $6 / 28 / 2011$ & $7 / 5 / 2011$ & 0.625 & 0.058 & 0.174 & 0.053 & 0.125 & 0.756 & 0.268 & 0.081 & 0.522 & 6.13 & 6.7 & 1670 & 24.38 & 24.38 & $\mathrm{~W}$ & $*$ & $\mathrm{~B}$ \\
\hline CO89 & 7/5/2011 & $7 / 12 / 2011$ & 0.121 & 0.013 & 0.02 & 0.014 & 0.134 & 0.67 & 0.256 & 0.036 & 0.389 & 4.97 & 6.7 & 1263.9 & 19.56 & 19.56 & W & $*$ & $\mathrm{~B}$ \\
\hline CO89 & $7 / 12 / 2011$ & $7 / 19 / 2011$ & 0.207 & 0.017 & 0.018 & 0.036 & 0.338 & 1.279 & 0.552 & 0.047 & 0.62 & 5.06 & 8.1 & 2574.2 & 38.1 & 38.1 & W & $*$ & B \\
\hline CO89 & $7 / 19 / 2011$ & $7 / 26 / 2011$ & -- & -- & -- & -- & -- & -- & -- & -- & -- & -- & -- & 39.2 & 0.51 & 0.51 & W & $\mathrm{c}$ & $\mathrm{C}$ \\
\hline CO89 & $7 / 26 / 2011$ & 8/2/2011 & 0.114 & 0.013 & 0.013 & 0.021 & 0.352 & 1.231 & 0.552 & 0.046 & 0.627 & 4.83 & 9.1 & 724.8 & 10.16 & 10.16 & W & $*$ & B \\
\hline CO89 & $8 / 2 / 2011$ & 8/9/2011 & 0.105 & 0.017 & 0.018 & 0.027 & 0.233 & 1.723 & 0.57 & 0.081 & 0.522 & 4.7 & 12.8 & 155.4 & 2.29 & 2.29 & W & $*$ & $\mathrm{~B}$ \\
\hline CO89 & 8/9/2011 & $8 / 16 / 2011$ & 0.391 & 0.042 & 0.031 & 0.059 & 0.306 & 1.369 & 0.547 & 0.077 & 0.721 & 5.35 & 9.2 & 64.8 & 1.02 & 1.02 & W & $*$ & B \\
\hline CO89 & $8 / 16 / 2011$ & $8 / 23 / 2011$ & -- & -- & -- & -- & -- & -- & -- & -- & -- & -- & -- & 332.4 & 4.57 & 4.57 & W & $\mathrm{c}$ & $\mathrm{C}$ \\
\hline CO89 & $8 / 23 / 2011$ & $8 / 30 / 2011$ & 0.151 & 0.017 & 0.013 & 0.022 & 0.323 & 1.505 & 0.591 & 0.054 & 0.499 & 4.88 & 10 & 1028.2 & 14.99 & 14.99 & W & $*$ & B \\
\hline CO89 & $8 / 30 / 2011$ & 9/6/2011 & 0.193 & 0.024 & 0.028 & 0.043 & 0.25 & 1.027 & 0.426 & 0.084 & 0.569 & 5.16 & 7.3 & 851.4 & 12.19 & 12.19 & W & $*$ & B \\
\hline CO89 & 9/6/2011 & $9 / 13 / 2011$ & 0.01 & 0.001 & 0.002 & 0.002 & 0.026 & 0.27 & 0.081 & 0.009 & 0.136 & 5.11 & 3.6 & 2023.5 & 33.53 & 33.53 & W & $*$ & A \\
\hline CO89 & $9 / 13 / 2011$ & $9 / 20 / 2011$ & 0.013 & 0.002 & 0.003 & 0.004 & 0.043 & 0.296 & 0.1 & 0.018 & 0.136 & 5.15 & 3.6 & 2079.8 & 36.32 & 36.32 & W & $*$ & B \\
\hline CO89 & $9 / 20 / 2011$ & $9 / 27 / 2011$ & 0.349 & 0.036 & 0.041 & 0.029 & 0.566 & 1.153 & 0.701 & 0.055 & 0.676 & 6.2 & 7.7 & 83.6 & 1.52 & 1.52 & W & $*$ & $\mathrm{~B}$ \\
\hline CO89 & $9 / 27 / 2011$ & $10 / 4 / 2011$ & -- & -- & -- & -- & -- & -- & -- & -- & -- & -- & -- & 239.2 & 3.3 & 3.3 & W & $\mathrm{c}$ & $\mathrm{C}$ \\
\hline CO89 & $10 / 4 / 2011$ & $10 / 11 / 2011$ & 0.085 & 0.01 & 0.033 & 0.006 & 0.08 & 0.494 & 0.174 & 0.024 & 0.194 & 5.26 & 4.2 & 832.9 & 23.37 & 23.37 & W & $*$ & B \\
\hline CO89 & $10 / 11 / 2011$ & $10 / 18 / 2011$ & 0.194 & 0.023 & 0.073 & 0.015 & 0.047 & 0.811 & 0.22 & 0.044 & 0.349 & 5.06 & 6.1 & 741.8 & 25.4 & 25.4 & W & $*$ & B \\
\hline CO89 & $10 / 18 / 2011$ & $10 / 25 / 2011$ & -- & -- & -- & -- & -- & -- & -- & -- & -- & -- & -- & 10.3 & 1.52 & 1.52 & $\mathrm{~T}$ & $\mathrm{v}$ & $\mathrm{C}$ \\
\hline CO89 & $10 / 25 / 2011$ & $11 / 1 / 2011$ & 0.027 & 0.004 & 0.004 & 0.004 & 0.059 & 0.152 & 0.08 & 0.003 & 0.149 & 5.5 & 2.4 & 1662.6 & 46.99 & 46.99 & W & $*$ & A \\
\hline CO89 & $11 / 1 / 2011$ & $11 / 8 / 2011$ & 0.065 & 0.007 & 0.007 & 0.013 & 0.141 & 0.536 & 0.231 & 0.013 & 0.193 & 5.48 & 3.4 & 1340.3 & 39.62 & 39.62 & W & $*$ & B \\
\hline CO89 & $11 / 8 / 2011$ & $11 / 15 / 2011$ & -- & -- & -- & -- & -- & -- & -- & -- & -- & -- & -- & 103.6 & 37.34 & 37.34 & W & $\mathrm{c}$ & $\mathrm{C}$ \\
\hline CO89 & $11 / 15 / 2011$ & $11 / 22 / 2011$ & 0.131 & 0.014 & 0.01 & 0.054 & 0.106 & 0.439 & 0.182 & 0.03 & 0.299 & 5.65 & 3.3 & 206.3 & 34.04 & 34.04 & W & $*$ & A \\
\hline
\end{tabular}


Table 1-1. Wet-deposition sample analysis data for colocated sites C089 and C098, water years 2010-14.-Continued

[Date on, start of weekly sample collection; Date off, end of weekly sample collection; $\mathrm{Ca}$, calcium; $\mathrm{Mg}$, magnesium; $\mathrm{K}$, potassium; $\mathrm{Na}$, sodium; $\mathrm{NH}_{4}$, ammonium; $\mathrm{NO}_{3}$, nitrate; $\mathrm{N}$, inorganic nitrogen; $\mathrm{Cl}$, chloride; $\mathrm{SO}_{4}$, sulfate; $\mathrm{pH}$, negative log of hydrogen-ion molarity; Cond, specific conductance in microSeimens per centimeter; Svol, sample volume in milliliters; RG ppt, rain gage precipitation depth in millimeters; Sub ppt, sample volume converted to depth substituted for missing weekly RG ppt. Lab types: W, sufficient volume for analysis; WD, dilution necessary to obtain volume for analysis; D, valid dry week; T, valid trace sample with insufficient volume for analysis. Inval codes: b, bulk sample (collector was open continuously); c, contaminated; d, debris; e, extended sampling period greater than 8 days; h, handling protocol problems; m, missing data; u, undefined; $v$, inadequate volume for analysis; $\mathrm{z}$, site operation problems; *, no Inval code assigned. QR (Quality Rating) codes: A, highest quality rating;

B, valid with minor problems; C, invalid. Concentrations in milligrams per liter. Valid dry week samples have no chemical data and have QR code of A. --, no data]

\begin{tabular}{|c|c|c|c|c|c|c|c|c|c|c|c|c|c|c|c|c|c|c|c|}
\hline Site & Date on & Date off & $\mathrm{Ca}$ & Mg & $\mathbf{K}$ & $\mathrm{Na}$ & $\mathrm{NH}_{4}$ & $\mathrm{NO}_{3}$ & $\mathbf{N}$ & CI & $\mathrm{SO}_{4}$ & $\mathrm{pH}$ & Cond & Svol & $\begin{array}{l}\text { RG } \\
\text { ppt }\end{array}$ & $\begin{array}{l}\text { Sub } \\
\text { ppt }\end{array}$ & $\begin{array}{l}\text { Lab } \\
\text { type }\end{array}$ & $\begin{array}{l}\text { Inval } \\
\text { codes }\end{array}$ & $\begin{array}{c}\text { OR } \\
\text { code }\end{array}$ \\
\hline CO89 & $11 / 22 / 2011$ & $11 / 29 / 2011$ & 0.102 & 0.012 & 0.016 & 0.02 & 0.182 & 0.332 & 0.217 & 0.021 & 0.288 & 5.49 & 3.9 & 69.3 & 10.67 & 10.67 & $\mathrm{~W}$ & $*$ & A \\
\hline CO89 & $11 / 29 / 2011$ & $12 / 6 / 2011$ & 0.062 & 0.005 & 0.004 & 0.006 & 0.096 & 0.644 & 0.22 & 0.017 & 0.079 & 5.2 & 4 & 1071.5 & 28.19 & 28.19 & W & $*$ & A \\
\hline CO89 & $12 / 6 / 2011$ & $12 / 13 / 2011$ & -- & -- & -- & -- & -- & -- & -- & -- & -- & -- & -- & 4 & 3.05 & 3.05 & $\mathrm{~T}$ & $\mathrm{v}$ & $\mathrm{C}$ \\
\hline CO89 & $12 / 13 / 2011$ & $12 / 20 / 2011$ & -- & -- & -- & -- & -- & -- & -- & -- & -- & -- & -- & 2.8 & 1.27 & 1.27 & $\mathrm{~T}$ & $\mathrm{v}$ & $\mathrm{C}$ \\
\hline CO89 & $12 / 20 / 2011$ & $12 / 27 / 2011$ & 0.01 & 0.001 & 0.006 & 0.018 & 0.052 & 0.298 & 0.108 & 0.018 & 0.062 & 5.42 & 2.6 & 973.2 & 24.89 & 24.89 & W & $*$ & A \\
\hline CO89 & $12 / 27 / 2011$ & $1 / 3 / 2012$ & -- & -- & -- & -- & -- & -- & -- & -- & -- & -- & -- & 37.3 & 15.24 & 15.24 & W & $\mathrm{c}$ & $\mathrm{C}$ \\
\hline CO89 & 1/3/2012 & $1 / 10 / 2012$ & 0.008 & 0.001 & 0.002 & 0.004 & 0.026 & 0.213 & 0.068 & 0.009 & 0.045 & 5.24 & 2.3 & 715.5 & 15.75 & 15.75 & W & $*$ & A \\
\hline CO89 & $1 / 10 / 2012$ & $1 / 17 / 2012$ & 0.12 & 0.015 & 0.013 & 0.028 & 0.124 & 0.598 & 0.232 & 0.027 & 0.271 & 5.28 & 4.5 & 194.2 & 18.54 & 18.54 & W & $*$ & B \\
\hline CO89 & $1 / 17 / 2012$ & $1 / 24 / 2012$ & 0.291 & 0.04 & 0.033 & 0.117 & 0.112 & 0.567 & 0.215 & 0.128 & 0.35 & 5.9 & 4.4 & 121.8 & 56.9 & 56.9 & W & $*$ & B \\
\hline CO89 & $1 / 24 / 2012$ & $1 / 31 / 2012$ & 0.223 & 0.023 & 0.025 & 0.051 & 0.185 & 0.675 & 0.296 & 0.061 & 0.519 & 5.35 & 5.5 & 108.6 & 13.21 & 13.21 & W & $*$ & B \\
\hline CO89 & $1 / 31 / 2012$ & 2/7/2012 & -- & -- & -- & -- & -- & -- & -- & -- & -- & -- & -- & 1167.2 & 35.56 & 35.56 & W & $\mathrm{u}$ & $\mathrm{C}$ \\
\hline CO89 & $2 / 7 / 2012$ & $2 / 14 / 2012$ & 0.045 & 0.006 & 0.006 & 0.014 & 0.075 & 0.273 & 0.12 & 0.016 & 0.233 & 5.28 & 3.7 & 697.9 & 37.08 & 37.08 & W & $*$ & B \\
\hline CO89 & $2 / 14 / 2012$ & $2 / 21 / 2012$ & 0.109 & 0.011 & 0.008 & 0.024 & 0.104 & 0.622 & 0.221 & 0.033 & 0.24 & 5.21 & 4.8 & 282.8 & 19.81 & 19.81 & W & $*$ & B \\
\hline CO89 & $2 / 21 / 2012$ & $2 / 28 / 2012$ & -- & -- & -- & -- & -- & -- & -- & -- & -- & -- & -- & 361.1 & 74.93 & 74.93 & W & $\mathrm{c}$ & $\mathrm{C}$ \\
\hline CO89 & $2 / 28 / 2012$ & $3 / 6 / 2012$ & -- & -- & -- & -- & -- & -- & -- & -- & -- & -- & -- & 255.5 & 37.85 & 37.85 & W & $\mathrm{c}$ & $\mathrm{C}$ \\
\hline CO89 & $3 / 6 / 2012$ & $3 / 13 / 2012$ & -- & -- & -- & -- & -- & -- & -- & -- & -- & -- & -- & 0 & 0 & 0 & $\mathrm{D}$ & $*$ & A \\
\hline CO89 & $3 / 13 / 2012$ & $3 / 20 / 2012$ & -- & -- & -- & -- & -- & -- & -- & -- & -- & -- & -- & 135.4 & 11.43 & 11.43 & W & $\mathrm{c}$ & $\mathrm{C}$ \\
\hline CO89 & $3 / 20 / 2012$ & $3 / 27 / 2012$ & -- & -- & -- & -- & -- & -- & -- & -- & -- & -- & -- & 0 & 0 & 0 & $\mathrm{D}$ & $*$ & A \\
\hline CO89 & $3 / 27 / 2012$ & 4/3/2012 & 0.319 & 0.037 & 0.025 & 0.066 & 0.591 & 0.686 & 0.615 & 0.056 & 0.481 & 6.55 & 7.1 & 981.3 & 20.32 & 20.32 & W & $*$ & B \\
\hline CO89 & 4/3/2012 & $4 / 10 / 2012$ & 0.258 & 0.026 & 0.011 & 0.043 & 0.237 & 0.462 & 0.289 & 0.067 & 0.221 & 5.88 & 4.5 & 28.7 & 0.51 & 0.51 & WD & $*$ & B \\
\hline CO89 & $4 / 10 / 2012$ & $4 / 17 / 2012$ & 0.148 & 0.016 & 0.015 & 0.021 & 0.361 & 0.818 & 0.466 & 0.043 & 0.611 & 5.65 & 5.4 & 1475.9 & 36.07 & 36.07 & $\mathrm{~W}$ & $*$ & B \\
\hline CO89 & $4 / 17 / 2012$ & $4 / 24 / 2012$ & 0.087 & 0.013 & 0.005 & 0.009 & 0.078 & 0.278 & 0.123 & 0.023 & 0.236 & 5.54 & 3.1 & 249.6 & 11.43 & 11.43 & W & $*$ & A \\
\hline CO89 & $4 / 24 / 2012$ & $5 / 1 / 2012$ & -- & -- & -- & -- & -- & -- & -- & -- & -- & -- & -- & 472.1 & 15.49 & 15.49 & W & $\mathrm{c}$ & B \\
\hline CO89 & $5 / 1 / 2012$ & $5 / 8 / 2012$ & -- & -- & -- & -- & -- & -- & -- & -- & -- & -- & -- & 1103.9 & 27.94 & 27.94 & W & $\mathrm{c}$ & A \\
\hline CO89 & $5 / 8 / 2012$ & $5 / 15 / 2012$ & -- & -- & -- & -- & -- & -- & -- & -- & -- & -- & -- & 511.2 & 9.65 & 9.65 & W & $\mathrm{c}$ & A \\
\hline CO89 & $5 / 15 / 2012$ & $5 / 22 / 2012$ & -- & -- & -- & -- & -- & -- & -- & -- & -- & -- & -- & 765 & 13.97 & 13.97 & W & $\mathrm{c}$ & A \\
\hline CO89 & $5 / 22 / 2012$ & $5 / 29 / 2012$ & -- & -- & -- & -- & -- & -- & -- & -- & -- & -- & -- & 990.6 & 27.43 & 27.43 & W & $\mathrm{c}$ & B \\
\hline CO89 & $5 / 29 / 2012$ & $6 / 5 / 2012$ & 0.508 & 0.062 & 0.12 & 0.031 & 0.043 & 0.657 & 0.182 & 0.079 & 0.411 & 5.8 & 5.2 & 596.7 & 8.89 & 8.89 & W & $*$ & B \\
\hline CO89 & $6 / 5 / 2012$ & $6 / 12 / 2012$ & -- & -- & -- & -- & -- & -- & -- & -- & -- & -- & -- & 19.1 & 0.25 & 0.25 & $\mathrm{~T}$ & $\mathrm{v}$ & $\mathrm{C}$ \\
\hline CO89 & $6 / 12 / 2012$ & $6 / 19 / 2012$ & -- & -- & -- & -- & -- & -- & -- & -- & -- & -- & -- & 0.1 & 0.51 & 0.51 & $\mathrm{~T}$ & $\mathrm{v}$ & $\mathrm{C}$ \\
\hline CO89 & $6 / 26 / 2012$ & $7 / 3 / 2012$ & -- & -- & -- & -- & -- & -- & -- & -- & -- & -- & -- & 549.3 & 9.4 & 9.4 & W & $\mathrm{c}$ & B \\
\hline CO89 & 7/3/2012 & $7 / 10 / 2012$ & 0.123 & 0.013 & 0.025 & 0.012 & 0.353 & 0.993 & 0.499 & 0.029 & 0.389 & 5.42 & 5.9 & 2538 & 39.12 & 39.12 & W & $*$ & A \\
\hline CO89 & $7 / 10 / 2012$ & $7 / 17 / 2012$ & -- & -- & -- & -- & -- & -- & -- & -- & -- & -- & -- & 470.3 & 7.11 & 7.11 & W & $\mathrm{c}$ & $\mathrm{C}$ \\
\hline
\end{tabular}


[Date on, start of weekly sample collection; Date off, end of weekly sample collection; Ca, calcium; $\mathrm{Mg}$, magnesium; $\mathrm{K}$, potassium; $\mathrm{Na}$, sodium; $\mathrm{NH}_{4}$, ammonium; $\mathrm{NO}_{3}$, nitrate; $\mathrm{N}$, inorganic nitrogen; $\mathrm{Cl}$, chloride; $\mathrm{SO}_{4}$, sulfate; $\mathrm{pH}$, negative log of hydrogen-ion molarity; Cond, specific conductance in microSeimens per centimeter; Svol, sample volume in milliliters; RG ppt, rain gage precipitation depth in millimeters; Sub ppt, sample volume converted to depth substituted for missing weekly RG ppt. Lab types: W, sufficient volume for analysis; WD, dilution necessary to obtain volume for analysis; D, valid dry week; T, valid trace sample with insufficient volume for analysis. Inval codes: b, bulk sample (collector was open continuously); c, contaminated; d, debris; e, extended sampling period greater than 8 days; h, handling protocol problems; m, missing data; u, undefined; v, inadequate volume for analysis; z, site operation problems; *, no Inval code assigned. QR (Quality Rating) codes: A, highest quality rating; B, valid with minor problems; C, invalid. Concentrations in milligrams per liter. Valid dry week samples have no chemical data and have QR code of A. --, no data]

\begin{tabular}{|c|c|c|c|c|c|c|c|c|c|c|c|c|c|c|c|c|c|c|c|}
\hline Site & Date on & Date off & $\mathrm{Ca}$ & Mg & $\mathbf{K}$ & $\mathrm{Na}$ & $\mathrm{NH}_{4}$ & $\mathrm{NO}_{3}$ & $\mathbf{N}$ & Cl & $\mathrm{SO}_{4}$ & $\mathrm{pH}$ & Cond & Svol & $\begin{array}{l}\text { RG } \\
\text { ppt }\end{array}$ & $\begin{array}{l}\text { Sub } \\
\text { ppt }\end{array}$ & $\begin{array}{l}\text { Lab } \\
\text { type }\end{array}$ & $\begin{array}{l}\text { Inval } \\
\text { codes }\end{array}$ & $\begin{array}{c}\mathrm{OR} \\
\text { code }\end{array}$ \\
\hline CO89 & $7 / 17 / 2012$ & $7 / 24 / 2012$ & -- & -- & -- & -- & -- & -- & -- & -- & -- & -- & -- & 323.9 & 5.33 & 5.33 & $\mathrm{~W}$ & $\mathrm{c}$ & $\mathrm{C}$ \\
\hline CO89 & $7 / 24 / 2012$ & $7 / 31 / 2012$ & 0.095 & 0.01 & 0.012 & 0.015 & 0.253 & 0.855 & 0.39 & 0.031 & 0.432 & 5.22 & 5.9 & 2909.7 & 44.96 & 44.96 & W & $*$ & B \\
\hline CO89 & $7 / 31 / 2012$ & 8/7/2012 & 0.267 & 0.032 & 0.025 & 0.026 & 0.269 & 1.31 & 0.505 & 0.069 & 0.513 & 5.18 & 7.5 & 557.6 & 7.62 & 7.62 & W & $*$ & B \\
\hline CO89 & 8/7/2012 & $8 / 14 / 2012$ & 0.401 & 0.038 & 0.106 & 0.041 & 0.661 & 1.742 & 0.908 & 0.107 & 0.848 & 5.68 & 9.6 & 68.9 & 1.27 & 1.27 & W & $*$ & A \\
\hline CO89 & $8 / 14 / 2012$ & $8 / 21 / 2012$ & -- & -- & -- & -- & -- & -- & -- & -- & -- & -- & -- & 4.7 & 0 & 0 & $\mathrm{~T}$ & $*$ & A \\
\hline CO89 & $8 / 21 / 2012$ & $8 / 28 / 2012$ & 0.148 & 0.017 & 0.034 & 0.016 & 0.392 & 1.141 & 0.563 & 0.057 & 0.396 & 5.15 & 7 & 709.6 & 10.92 & 10.92 & $\mathrm{~W}$ & $*$ & B \\
\hline CO89 & $8 / 28 / 2012$ & 9/4/2012 & 0.22 & 0.026 & 0.017 & 0.027 & 0.402 & 1.432 & 0.636 & 0.057 & 0.634 & 5.16 & 8.5 & 1241.6 & 18.8 & 18.8 & W & $*$ & B \\
\hline CO89 & $9 / 4 / 2012$ & $9 / 11 / 2012$ & -- & -- & -- & -- & -- & -- & -- & -- & -- & -- & -- & 385.2 & 5.59 & 5.59 & W & $\mathrm{c}$ & A \\
\hline CO89 & $9 / 11 / 2012$ & $9 / 18 / 2012$ & 0.1 & 0.012 & 0.011 & 0.01 & 0.116 & 0.416 & 0.184 & 0.023 & 0.169 & 5.56 & 3.1 & 1979.2 & 30.99 & 30.99 & W & $*$ & B \\
\hline CO89 & $9 / 18 / 2012$ & $9 / 25 / 2012$ & 0.198 & 0.024 & 0.015 & 0.039 & 0.469 & 1.301 & 0.659 & 0.095 & 0.948 & 4.96 & 9.7 & 348.8 & 6.1 & 6.1 & W & $*$ & $\mathrm{~A}$ \\
\hline CO89 & $9 / 25 / 2012$ & $10 / 2 / 2012$ & 0.027 & 0.003 & 0.003 & 0.003 & 0.141 & 0.33 & 0.184 & 0.011 & 0.188 & 5.39 & 3.2 & 2564.3 & 37.59 & 37.59 & W & $*$ & A \\
\hline CO89 & $10 / 2 / 2012$ & $10 / 9 / 2012$ & 0.853 & 0.091 & 0.07 & 0.189 & 0.283 & 1.59 & 0.579 & 0.141 & 0.896 & 6.5 & 9.9 & 60.4 & 1.52 & 1.52 & W & $*$ & A \\
\hline CO89 & $10 / 9 / 2012$ & $10 / 16 / 2012$ & 0.073 & 0.009 & 0.011 & 0.012 & 0.11 & 0.367 & 0.168 & 0.027 & 0.261 & 5.23 & 3.7 & 416 & 20.83 & 20.83 & W & $*$ & A \\
\hline CO89 & $10 / 16 / 2012$ & $10 / 23 / 2012$ & 0.306 & 0.047 & 0.036 & 0.028 & 0.152 & 0.562 & 0.245 & 0.034 & 0.446 & 5.76 & 4.4 & 395.5 & 10.67 & 10.67 & W & $*$ & B \\
\hline CO89 & $10 / 23 / 2012$ & $10 / 30 / 2012$ & 0.161 & 0.018 & 0.013 & 0.035 & 0.103 & 0.577 & 0.21 & 0.024 & 0.457 & 5.4 & 4.5 & 629.1 & 21.84 & 21.84 & W & $*$ & B \\
\hline CO89 & $10 / 30 / 2012$ & $11 / 6 / 2012$ & -- & -- & -- & -- & -- & -- & -- & -- & -- & -- & -- & 0.2 & 0 & 0 & $\mathrm{~T}$ & $*$ & A \\
\hline CO89 & $11 / 6 / 2012$ & $11 / 13 / 2012$ & 0.141 & 0.014 & 0.013 & 0.016 & 0.048 & 0.255 & 0.095 & 0.017 & 0.154 & 5.7 & 2.4 & 288.1 & 20.83 & 20.83 & W & $*$ & B \\
\hline CO89 & $11 / 13 / 2012$ & $11 / 20 / 2012$ & 0.124 & 0.011 & 0.005 & 0.014 & 0.182 & 0.616 & 0.281 & 0.041 & 0.403 & 5.07 & 6 & 21 & 6.35 & 6.35 & WD & $*$ & B \\
\hline CO89 & $11 / 20 / 2012$ & $11 / 27 / 2012$ & -- & -- & -- & -- & -- & -- & -- & -- & -- & -- & -- & 0 & 0 & 0 & $\mathrm{D}$ & $*$ & A \\
\hline CO89 & $11 / 27 / 2012$ & $12 / 11 / 2012$ & -- & -- & -- & -- & -- & -- & -- & -- & -- & -- & -- & 149.1 & 39.88 & 39.88 & W & e & $\mathrm{C}$ \\
\hline CO89 & $12 / 11 / 2012$ & $12 / 18 / 2012$ & 0.029 & 0.004 & 0.011 & 0.01 & 0.058 & 0.167 & 0.083 & 0.015 & 0.16 & 5.44 & 2.6 & 469.5 & 32.77 & 32.77 & W & $*$ & A \\
\hline CO89 & $12 / 18 / 2012$ & $12 / 25 / 2012$ & 0.014 & 0.002 & 0.003 & 0.005 & 0.075 & 0.367 & 0.141 & 0.014 & 0.048 & 5.41 & 2.8 & 1223.8 & 32.26 & 32.26 & W & $*$ & A \\
\hline CO89 & $12 / 25 / 2012$ & $1 / 1 / 2013$ & -- & -- & -- & -- & -- & -- & -- & -- & -- & -- & -- & 17.9 & 9.91 & 9.91 & $\mathrm{~T}$ & $\mathrm{v}$ & $\mathrm{C}$ \\
\hline CO89 & $1 / 1 / 2013$ & $1 / 8 / 2013$ & -- & -- & -- & -- & -- & -- & -- & -- & -- & -- & -- & 0.2 & 0.76 & 0.76 & $\mathrm{~T}$ & $\mathrm{v}$ & $\mathrm{C}$ \\
\hline CO89 & $1 / 8 / 2013$ & $1 / 15 / 2013$ & 0.075 & 0.01 & 0.013 & 0.018 & 0.045 & 0.275 & 0.097 & 0.029 & 0.128 & 5.34 & 3.2 & 64.6 & 14.48 & 14.48 & W & $*$ & A \\
\hline CO89 & $1 / 15 / 2013$ & $1 / 22 / 2013$ & -- & -- & -- & -- & -- & -- & -- & -- & -- & -- & -- & 0.1 & 0 & 0 & $\mathrm{D}$ & $*$ & A \\
\hline CO89 & $1 / 22 / 2013$ & $1 / 29 / 2013$ & 0.035 & 0.004 & 0.006 & 0.008 & 0.063 & 0.371 & 0.133 & 0.016 & 0.059 & 5.27 & 3.3 & 192.7 & 16 & 16 & W & $*$ & B \\
\hline CO89 & $1 / 29 / 2013$ & $2 / 5 / 2013$ & 0.225 & 0.029 & 0.048 & 0.036 & 0.223 & 1.098 & 0.421 & 0.109 & 0.644 & 5.08 & 8.7 & 53.2 & 38.35 & 38.35 & W & $*$ & A \\
\hline CO89 & $2 / 5 / 2013$ & $2 / 12 / 2013$ & 0.028 & 0.004 & 0.003 & 0.009 & 0.038 & 0.281 & 0.093 & 0.015 & 0.116 & 5.31 & 3.5 & 335 & 16.51 & 16.51 & W & $*$ & A \\
\hline CO89 & $2 / 12 / 2013$ & $2 / 19 / 2013$ & 0.107 & 0.013 & 0.011 & 0.027 & 0.128 & 0.639 & 0.244 & 0.049 & 0.206 & 5.3 & 4.4 & 116.5 & 19.3 & 19.3 & W & $*$ & B \\
\hline CO89 & $2 / 19 / 2013$ & $2 / 26 / 2013$ & 0.061 & 0.004 & 0.005 & 0.018 & 0.087 & 0.39 & 0.156 & 0.019 & 0.091 & 5.52 & 2.6 & 729.7 & 18.03 & 18.03 & W & $*$ & A \\
\hline CO89 & $2 / 26 / 2013$ & $3 / 5 / 2013$ & 0.031 & 0.004 & 0.005 & 0.009 & 0.091 & 0.219 & 0.12 & 0.022 & 0.259 & 5.18 & 4.1 & 396 & 25.65 & 25.65 & W & $*$ & A \\
\hline CO89 & $3 / 5 / 2013$ & $3 / 12 / 2013$ & 0.073 & 0.004 & 0.006 & 0.014 & 0.145 & 0.439 & 0.212 & 0.025 & 0.158 & 5.68 & 2.9 & 661.9 & 26.67 & 26.67 & W & $*$ & A \\
\hline
\end{tabular}


Table 1-1. Wet-deposition sample analysis data for colocated sites C089 and C098, water years 2010-14.-Continued

[Date on, start of weekly sample collection; Date off, end of weekly sample collection; $\mathrm{Ca}$, calcium; $\mathrm{Mg}$, magnesium; $\mathrm{K}$, potassium; $\mathrm{Na}$, sodium; $\mathrm{NH}$, ammonium; $\mathrm{NO}$, nitrate; $\mathrm{N}$, inorganic nitrogen; $\mathrm{Cl}$, chloride; $\mathrm{SO}_{4}$, sulfate; $\mathrm{pH}$, negative log of hydrogen-ion molarity; Cond, specific conductance in microSeimens per centimeter; Svol, sample volume in milliliters; RG ppt, rain gage precipitation depth in millimeters; Sub ppt, sample volume converted to depth substituted for missing weekly RG ppt. Lab types: W, sufficient volume for analysis; WD, dilution necessary to obtain volume for analysis; D, valid dry week; T, valid trace sample with insufficient volume for analysis. Inval codes: b, bulk sample (collector was open continuously); c, contaminated; d, debris; e, extended sampling period greater than 8 days; h, handling protocol problems; m, missing data; u, undefined; v, inadequate volume for analysis; z, site operation problems; *, no Inval code assigned. QR (Quality Rating) codes: A, highest quality rating;

$\mathrm{B}$, valid with minor problems; $\mathrm{C}$, invalid. Concentrations in milligrams per liter. Valid dry week samples have no chemical data and have QR code of A. --, no data]

\begin{tabular}{|c|c|c|c|c|c|c|c|c|c|c|c|c|c|c|c|c|c|c|c|}
\hline Site & Date on & Date off & $\mathrm{Ca}$ & Mg & K & $\mathrm{Na}$ & $\mathrm{NH}_{4}$ & $\mathrm{NO}_{3}$ & $\mathbf{N}$ & Cl & $\mathrm{SO}_{4}$ & $\mathrm{pH}$ & Cond & Svol & $\begin{array}{l}\text { RG } \\
\text { ppt }\end{array}$ & $\begin{array}{l}\text { Sub } \\
\text { ppt }\end{array}$ & $\begin{array}{l}\text { Lab } \\
\text { type }\end{array}$ & $\begin{array}{l}\text { Inval } \\
\text { codes }\end{array}$ & $\begin{array}{c}\text { QR } \\
\text { code }\end{array}$ \\
\hline CO89 & $3 / 12 / 2013$ & $3 / 19 / 2013$ & 0.576 & 0.066 & 0.032 & 0.122 & 0.603 & 2.223 & 0.971 & 0.222 & 1.006 & 5.69 & 10.6 & 226.7 & 20.07 & 20.07 & $\mathrm{~W}$ & $*$ & A \\
\hline CO89 & $3 / 19 / 2013$ & $3 / 26 / 2013$ & 0.14 & 0.016 & 0.01 & 0.065 & 0.149 & 0.324 & 0.189 & 0.054 & 0.262 & 5.99 & 3 & 1149.5 & 34.8 & 34.8 & W & $*$ & A \\
\hline CO89 & $3 / 26 / 2013$ & $4 / 2 / 2013$ & 0.308 & 0.038 & 0.021 & 0.065 & 0.542 & 1.552 & 0.772 & 0.102 & 0.679 & 5.99 & 7.6 & 946.1 & 22.35 & 22.35 & W & $*$ & A \\
\hline CO89 & $4 / 2 / 2013$ & 4/9/2013 & 0.442 & 0.034 & 0.029 & 0.045 & 0.386 & 0.626 & 0.442 & 0.052 & 0.513 & 6.55 & 6.2 & 1816.8 & 44.7 & 44.7 & W & $*$ & A \\
\hline CO89 & 4/9/2013 & $4 / 23 / 2013$ & -- & -- & -- & -- & -- & -- & -- & -- & -- & -- & -- & 2848 & 214.38 & 214.38 & $\mathrm{~W}$ & e & $\mathrm{C}$ \\
\hline CO89 & $4 / 23 / 2013$ & $4 / 30 / 2013$ & 2.208 & 0.249 & 0.081 & 0.346 & 1.081 & 4.125 & 1.773 & 0.403 & 2.763 & 6.74 & 26.7 & 21.5 & 17.78 & 17.78 & WD & $*$ & B \\
\hline CO89 & $4 / 30 / 2013$ & $5 / 7 / 2013$ & 1.019 & 0.109 & 0.055 & 0.135 & 0.461 & 1.174 & 0.624 & 0.108 & 0.795 & 6.79 & 10.9 & 2169.3 & 67.31 & 67.31 & $\mathrm{~W}$ & $*$ & B \\
\hline CO89 & $5 / 7 / 2013$ & $5 / 14 / 2013$ & -- & -- & -- & -- & -- & -- & -- & -- & -- & -- & -- & 3073.8 & 69.34 & 69.34 & W & $\mathrm{b}$ & $\mathrm{C}$ \\
\hline CO89 & $5 / 14 / 2013$ & $5 / 21 / 2013$ & -- & -- & -- & -- & -- & -- & -- & -- & -- & -- & -- & 431.1 & 8.38 & 8.38 & W & $\mathrm{c}$ & $\mathrm{C}$ \\
\hline CO89 & $5 / 21 / 2013$ & $6 / 4 / 2013$ & -- & -- & -- & -- & -- & -- & -- & -- & -- & -- & 3.5 & 760.5 & 20.83 & 20.83 & W & $\mathrm{e}$ & $\mathrm{C}$ \\
\hline CO89 & $6 / 4 / 2013$ & $6 / 11 / 2013$ & 0.652 & 0.088 & 0.045 & 0.113 & 0.54 & 2.216 & 0.921 & 0.17 & 0.979 & 5.53 & 11.9 & 76.2 & 0.51 & 0.51 & W & $*$ & A \\
\hline CO89 & $6 / 11 / 2013$ & $6 / 18 / 2013$ & 1.112 & 0.164 & 0.465 & 0.19 & 0.477 & 2.014 & 0.826 & 0.332 & 1.435 & 6.47 & 14.6 & 195.9 & 2.54 & 2.54 & W & $*$ & A \\
\hline CO89 & $6 / 18 / 2013$ & $6 / 25 / 2013$ & -- & -- & -- & -- & -- & -- & -- & -- & -- & -- & -- & 0.9 & 0 & 0 & $\mathrm{D}$ & $*$ & A \\
\hline CO89 & $6 / 25 / 2013$ & $7 / 2 / 2013$ & 0.273 & 0.036 & 0.077 & 0.023 & 0.663 & 1.105 & 0.765 & 0.072 & 0.494 & 6.11 & 7.6 & 615.6 & 9.91 & 9.91 & W & $*$ & A \\
\hline CO89 & $7 / 2 / 2013$ & 7/9/2013 & 0.087 & 0.012 & & & 0.241 & & & 0.045 & & 5.4 & 4.5 & 2426.3 & 36.83 & 36.83 & W & $*$ & B \\
\hline CO89 & 7/9/2013 & $7 / 16 / 2013$ & 0.067 & 0.009 & 0.016 & 0.009 & 0.417 & 0.834 & 0.513 & 0.025 & 0.322 & 5.56 & 5.3 & 1408.3 & 21.59 & 21.59 & $\mathrm{~W}$ & $*$ & A \\
\hline CO89 & $7 / 16 / 2013$ & $7 / 23 / 2013$ & 0.114 & 0.016 & 0.014 & 0.01 & 0.252 & 1.072 & 0.438 & 0.032 & 0.458 & 4.9 & 8.2 & 635 & 10.16 & 10.16 & W & $*$ & B \\
\hline CO89 & $7 / 23 / 2013$ & $7 / 30 / 2013$ & 0.122 & 0.014 & 0.011 & 0.012 & 0.209 & 0.648 & 0.309 & 0.037 & 0.258 & 5.34 & 5.1 & 1714.8 & 26.67 & 26.67 & W & $*$ & B \\
\hline CO89 & $7 / 30 / 2013$ & $8 / 6 / 2013$ & 0.399 & 0.056 & 0.021 & 0.115 & 0.44 & 2.248 & 0.85 & 0.174 & 1.355 & 4.75 & 16.5 & 266.9 & 3.81 & 3.81 & W & $*$ & B \\
\hline CO89 & $8 / 6 / 2013$ & $8 / 13 / 2013$ & 0.175 & & & & & & & & & 5.92 & 7.5 & & -- & 10.83 & W & $*$ & B \\
\hline CO89 & $8 / 13 / 2013$ & $8 / 20 / 2013$ & 0.107 & 0.014 & 0.008 & 0.011 & 0.178 & 0.744 & 0.307 & 0.043 & 0.475 & 5.02 & 6.8 & 448.5 & -- & 6.61 & W & $*$ & B \\
\hline CO89 & $8 / 20 / 2013$ & $8 / 27 / 2013$ & 0.088 & 0.009 & 0.015 & 0.009 & 0.184 & 0.701 & 0.301 & 0.034 & 0.436 & 5.02 & 6.8 & 1176.4 & & 18.03 & W & $*$ & B \\
\hline CO89 & $8 / 27 / 2013$ & $9 / 3 / 2013$ & 0.108 & 0.011 & 0.013 & 0.012 & 0.278 & 0.879 & 0.415 & 0.033 & 0.508 & 5.14 & 7 & 1711.3 & 26.42 & 26.42 & W & $*$ & B \\
\hline CO89 & $9 / 3 / 2013$ & $9 / 10 / 2013$ & 0.202 & 0.016 & 0.019 & 0.014 & 0.454 & 1.244 & 0.634 & 0.043 & 0.502 & 5.61 & 6.7 & 1934.9 & 29.72 & 29.72 & W & $*$ & B \\
\hline CO89 & $9 / 10 / 2013$ & $9 / 19 / 2013$ & -- & -- & -- & -- & -- & -- & -- & -- & -- & -- & -- & -- & 155.7 & 155.7 & W & e & $\mathrm{C}$ \\
\hline CO89 & $9 / 19 / 2013$ & $9 / 24 / 2013$ & 0.001 & 0.009 & 0.019 & 0.009 & 0.049 & 0.29 & 0.104 & 0.026 & 0.136 & 5.32 & 3.4 & 1328.5 & 30.48 & 30.48 & W & $*$ & B \\
\hline CO89 & $9 / 24 / 2013$ & 9/30/2013 & 0.116 & 0.009 & 0.017 & 0.012 & 0.034 & 0.159 & 0.062 & 0.023 & 0.139 & 5.81 & 2.3 & 655 & 22.35 & 22.35 & W & $*$ & B \\
\hline CO89 & $9 / 30 / 2013$ & $10 / 15 / 2013$ & -- & -- & -- & -- & -- & -- & -- & -- & -- & -- & -- & 790.6 & 49.02 & 49.02 & W & $\mathrm{e}$ & $\mathrm{C}$ \\
\hline CO89 & $10 / 15 / 2013$ & $10 / 22 / 2013$ & 0.03 & 0.009 & 0.023 & 0.003 & 0.191 & 0.335 & 0.224 & 0.016 & 0.354 & 5.36 & 4.1 & 569.7 & 17.78 & 17.78 & W & $*$ & B \\
\hline CO89 & $10 / 22 / 2013$ & $10 / 29 / 2013$ & -- & -- & -- & -- & -- & -- & -- & -- & -- & -- & -- & 0 & 0 & 0 & $\mathrm{D}$ & $*$ & A \\
\hline CO89 & $10 / 29 / 2013$ & $11 / 5 / 2013$ & 0.1 & 0.01 & 0.011 & 0.027 & 0.136 & 0.524 & 0.224 & 0.032 & 0.293 & 5.43 & 4.2 & 428.4 & 43.18 & 43.18 & W & $*$ & A \\
\hline CO89 & $11 / 5 / 2013$ & $11 / 12 / 2013$ & -- & -- & -- & -- & -- & -- & -- & -- & -- & -- & -- & 0.7 & 2.03 & 2.03 & $\mathrm{~T}$ & $\mathrm{v}$ & $\mathrm{C}$ \\
\hline CO89 & $11 / 12 / 2013$ & $11 / 19 / 2013$ & 0.06 & 0.012 & 0.008 & 0.009 & 0.175 & 0.659 & 0.285 & 0.018 & 0.25 & 5.1 & 5.5 & 207.8 & 42.16 & 42.16 & W & $*$ & B \\
\hline
\end{tabular}


[Date on, start of weekly sample collection; Date off, end of weekly sample collection; Ca, calcium; $\mathrm{Mg}$, magnesium; $\mathrm{K}$, potassium; $\mathrm{Na}$, sodium; $\mathrm{NH}_{4}$, ammonium; $\mathrm{NO}_{3}$, nitrate; $\mathrm{N}$, inorganic nitrogen; $\mathrm{Cl}$, chloride; $\mathrm{SO}_{4}$, sulfate; $\mathrm{pH}$, negative log of hydrogen-ion molarity; Cond, specific conductance in microSeimens per centimeter; Svol, sample volume in milliliters; RG ppt, rain gage precipitation depth in millimeters; Sub ppt, sample volume converted to depth substituted for missing weekly RG ppt. Lab types: W, sufficient volume for analysis; WD, dilution necessary to obtain volume for analysis; D, valid dry week; T, valid trace sample with insufficient volume for analysis. Inval codes: b, bulk sample (collector was open continuously); c, contaminated; d, debris; e, extended sampling period greater than 8 days; h, handling protocol problems; m, missing data; u, undefined; v, inadequate volume for analysis; z, site operation problems; *, no Inval code assigned. QR (Quality Rating) codes: A, highest quality rating; B, valid with minor problems; C, invalid. Concentrations in milligrams per liter. Valid dry week samples have no chemical data and have QR code of A. --, no data]

\begin{tabular}{|c|c|c|c|c|c|c|c|c|c|c|c|c|c|c|c|c|c|c|c|}
\hline Site & Date on & Date off & $\mathrm{Ca}$ & Mg & $\mathbf{K}$ & $\mathrm{Na}$ & $\mathrm{NH}_{4}$ & $\mathrm{NO}_{3}$ & $\mathbf{N}$ & Cl & $\mathrm{SO}_{4}$ & $\mathrm{pH}$ & Cond & Svol & $\begin{array}{l}\text { RG } \\
\text { ppt }\end{array}$ & $\begin{array}{l}\text { Sub } \\
\text { ppt }\end{array}$ & $\begin{array}{l}\text { Lab } \\
\text { type }\end{array}$ & $\begin{array}{l}\text { Inval } \\
\text { codes }\end{array}$ & $\begin{array}{c}\mathrm{OR} \\
\text { code }\end{array}$ \\
\hline CO89 & $11 / 19 / 2013$ & $11 / 26 / 2013$ & 0.001 & 0.009 & 0.003 & 0.004 & 0.064 & 0.203 & 0.096 & 0.006 & 0.05 & 5.37 & 2.7 & 1149.1 & 23.88 & 23.88 & $\mathrm{~W}$ & $*$ & A \\
\hline CO89 & $11 / 26 / 2013$ & $12 / 11 / 2013$ & -- & -- & -- & -- & -- & -- & -- & -- & -- & -- & -- & 1177.6 & 66.55 & 66.55 & W & e & $\mathrm{C}$ \\
\hline CO89 & $12 / 11 / 2013$ & $12 / 17 / 2013$ & -- & -- & -- & -- & -- & -- & -- & -- & -- & -- & -- & 0 & 2.03 & 2.03 & $\mathrm{D}$ & $\mathrm{v}$ & $\mathrm{C}$ \\
\hline CO89 & $12 / 17 / 2013$ & $12 / 24 / 2013$ & 0.048 & 0.005 & 0.056 & 0.028 & 0.063 & 0.435 & 0.147 & 0.073 & 0.122 & 5.28 & 4 & 50.4 & 32.77 & 32.77 & WD & $*$ & B \\
\hline CO89 & $12 / 24 / 2013$ & $12 / 31 / 2013$ & 0.031 & 0.002 & 0.002 & 0.009 & 0.044 & 0.361 & 0.116 & 0.014 & 0.066 & 5.24 & 3.3 & 411.5 & 13.72 & 13.72 & W & $*$ & A \\
\hline CO89 & $12 / 31 / 2013$ & $1 / 7 / 2014$ & 0.023 & 0.009 & 0.003 & 0.01 & 0.063 & 0.233 & 0.102 & 0.029 & 0.125 & 5.35 & 3 & 968 & 57.4 & 57.4 & W & $\mathrm{d}$ & B \\
\hline CO89 & $1 / 7 / 2014$ & $1 / 14 / 2014$ & 0.059 & 0.012 & 0.007 & 0.028 & 0.067 & 0.166 & 0.09 & 0.018 & 0.153 & 5.48 & 2.6 & 263.3 & 66.29 & 66.29 & W & $\mathrm{dzu}$ & $\mathrm{C}$ \\
\hline CO89 & $1 / 14 / 2014$ & $1 / 21 / 2014$ & -- & -- & -- & -- & -- & -- & -- & -- & -- & -- & -- & 1 & 3.56 & 3.56 & $\mathrm{~T}$ & $\mathrm{dv}$ & $\mathrm{C}$ \\
\hline CO89 & $1 / 21 / 2014$ & $1 / 28 / 2014$ & 0.03 & 0.009 & 0.003 & 0.007 & 0.138 & 0.524 & 0.226 & 0.037 & 0.14 & 5.09 & 5.3 & 537 & 28.96 & 28.96 & W & $*$ & A \\
\hline CO89 & $1 / 28 / 2014$ & $2 / 4 / 2014$ & 0.006 & 0.009 & 0.001 & 0.002 & 0.044 & 0.162 & 0.071 & 0.004 & 0.036 & 5.48 & 2.1 & 1242 & 58.93 & 58.93 & W & $*$ & A \\
\hline CO89 & $2 / 4 / 2014$ & $2 / 11 / 2014$ & 0.036 & 0.004 & 0.006 & 0.012 & 0.076 & 0.369 & 0.142 & 0.018 & 0.227 & 5.12 & 4.3 & 747.7 & 0 & 11.02 & W & $\mathrm{mz}$ & B \\
\hline CO89 & $2 / 11 / 2014$ & $2 / 18 / 2014$ & 0.069 & 0.008 & 0.006 & 0.019 & 0.128 & 0.416 & 0.194 & 0.028 & 0.416 & 5.13 & 4.9 & 710.1 & 84.58 & 84.58 & W & $*$ & A \\
\hline CO89 & $2 / 18 / 2014$ & $2 / 25 / 2014$ & 0.155 & 0.028 & 0.007 & 0.033 & 0.093 & 0.212 & 0.12 & 0.021 & 0.193 & 5.77 & 2.9 & 290.5 & 51.56 & 51.56 & W & $\mathrm{d}$ & B \\
\hline CO89 & $2 / 25 / 2014$ & $3 / 4 / 2014$ & 0.076 & 0.01 & 0.009 & 0.015 & 0.134 & 0.301 & 0.172 & 0.028 & 0.226 & 5.41 & 3.7 & 391.6 & 50.29 & 50.29 & W & $\mathrm{d}$ & B \\
\hline CO89 & $3 / 4 / 2014$ & $3 / 11 / 2014$ & 0.023 & 0.005 & 0.002 & 0.009 & 0.106 & 0.192 & 0.126 & 0.008 & 0.081 & 5.58 & 2.3 & 1848.7 & 41.66 & 41.66 & W & $*$ & A \\
\hline CO89 & $3 / 11 / 2014$ & $3 / 18 / 2014$ & 1.218 & 0.123 & 0.053 & 0.649 & 0.169 & 0.378 & 0.217 & 0.288 & 1.187 & 6.8 & 12.5 & 343.1 & 18.54 & 18.54 & W & $\mathrm{c}$ & $\mathrm{C}$ \\
\hline CO89 & $3 / 18 / 2014$ & $3 / 25 / 2014$ & 0.225 & 0.03 & 0.021 & 0.039 & 0.148 & 0.768 & 0.289 & 0.051 & 0.212 & 5.78 & 4 & 757.2 & 34.29 & 34.29 & W & $*$ & A \\
\hline CO89 & $3 / 25 / 2014$ & $4 / 1 / 2014$ & 2.563 & 0.117 & 0.058 & 0.037 & 0.117 & 0.421 & 0.186 & 0.033 & 0.335 & 7.19 & 15.3 & 773.9 & 67.31 & 67.31 & W & $\mathrm{d}$ & B \\
\hline CO89 & $4 / 1 / 2014$ & $4 / 8 / 2014$ & 0.083 & 0.008 & 0.004 & 0.012 & 0.088 & 0.231 & 0.121 & 0.014 & 0.18 & 5.63 & 2.4 & 836.1 & 31.5 & 31.5 & W & $*$ & A \\
\hline CO89 & $4 / 8 / 2014$ & $4 / 15 / 2014$ & 0.048 & 0.007 & 0.007 & 0.008 & 0.151 & 0.222 & 0.168 & 0.013 & 0.099 & 5.79 & 2.2 & 1452.1 & 45.97 & 45.97 & W & $*$ & A \\
\hline CO89 & $4 / 15 / 2014$ & $4 / 22 / 2014$ & 0.516 & 0.01 & 0.046 & 0.185 & 0.734 & 1.826 & 0.983 & 0.184 & 1.809 & 5.71 & 12.1 & 100.8 & 3.81 & 3.81 & W & $\mathrm{d}$ & B \\
\hline CO89 & $4 / 22 / 2014$ & $4 / 29 / 2014$ & 0.116 & 0.013 & 0.007 & 0.022 & 0.089 & 0.154 & 0.104 & 0.014 & 0.134 & 5.86 & 2.3 & 314.9 & 30.99 & 30.99 & W & $*$ & A \\
\hline CO89 & $4 / 29 / 2014$ & $5 / 6 / 2014$ & -- & -- & -- & -- & -- & -- & -- & -- & -- & 5.35 & 5.9 & 15.2 & 4.57 & 4.57 & $\mathrm{~T}$ & $\mathrm{v}$ & $\mathrm{C}$ \\
\hline CO89 & $5 / 6 / 2014$ & $5 / 13 / 2014$ & 0.138 & 0.016 & 0.01 & 0.029 & 0.129 & 0.277 & 0.163 & 0.037 & 0.194 & 5.88 & 2.7 & 2363.9 & 71.12 & 71.12 & W & $*$ & A \\
\hline CO89 & $5 / 13 / 2014$ & $5 / 20 / 2014$ & 0.17 & 0.033 & 0.012 & 0.061 & 0.178 & 0.602 & 0.274 & 0.083 & 0.36 & 5.6 & 4.2 & 833.3 & 14.99 & 14.99 & W & $*$ & A \\
\hline CO89 & $5 / 20 / 2014$ & $5 / 27 / 2014$ & 0.034 & 0.004 & 0.007 & 0.007 & 0.399 & 0.606 & 0.447 & 0.02 & 0.192 & 6.02 & 3.8 & 2699.6 & 38.1 & 38.1 & W & $*$ & A \\
\hline CO89 & $5 / 27 / 2014$ & $6 / 3 / 2014$ & 0.216 & 0.025 & 0.02 & 0.025 & 0.33 & 0.822 & 0.442 & 0.07 & 0.39 & 5.79 & 5.2 & 887.8 & 14.22 & 14.22 & W & $\mathrm{d}$ & B \\
\hline CO89 & $6 / 3 / 2014$ & $6 / 10 / 2014$ & 0.435 & 0.061 & 0.036 & 0.067 & 0.371 & 1.073 & 0.531 & 0.111 & 0.884 & 5.84 & 7.5 & 408.6 & 6.1 & 6.1 & W & $\mathrm{dh}$ & B \\
\hline CO89 & $6 / 10 / 2014$ & $6 / 17 / 2014$ & 1.186 & 0.141 & 0.096 & 0.298 & 0.83 & 2.345 & 1.175 & 0.406 & 1.587 & 6.43 & 16.5 & 337.3 & 4.83 & 4.83 & W & $\mathrm{dc}$ & $\mathrm{C}$ \\
\hline CO89 & $6 / 17 / 2014$ & $6 / 24 / 2014$ & 3.087 & 0.339 & 0.415 & 0.35 & 0.161 & 3.386 & 0.89 & 0.675 & 1.719 & 6.7 & 26.6 & 170.5 & 4.57 & 4.57 & W & $\mathrm{dc}$ & $\mathrm{C}$ \\
\hline CO89 & $6 / 24 / 2014$ & $7 / 1 / 2014$ & 0.303 & 0.047 & 0.132 & 0.029 & 0.006 & 0.557 & 0.13 & 0.066 & 0.356 & 5.49 & 4.6 & 290.9 & 3.81 & 3.81 & W & $\mathrm{d}$ & B \\
\hline CO89 & 7/1/2014 & $7 / 8 / 2014$ & 0.239 & 0.036 & 0.047 & 0.051 & 0.303 & 0.81 & 0.419 & 0.108 & 0.406 & 5.74 & 5.7 & 443.5 & 6.35 & 6.35 & W & $d$ & B \\
\hline CO89 & $7 / 8 / 2014$ & $7 / 15 / 2014$ & 0.126 & 0.017 & 0.023 & 0.018 & 0.249 & 0.783 & 0.371 & 0.044 & 0.255 & 5.39 & 5.1 & 628.6 & 9.14 & 9.14 & W & $\mathrm{d}$ & B \\
\hline
\end{tabular}


Table 1-1. Wet-deposition sample analysis data for colocated sites C089 and C098, water years 2010-14.-Continued

[Date on, start of weekly sample collection; Date off, end of weekly sample collection; $\mathrm{Ca}$, calcium; $\mathrm{Mg}$, magnesium; $\mathrm{K}$, potassium; $\mathrm{Na}$, sodium; $\mathrm{NH}_{4}$, ammonium; $\mathrm{NO}$, nitrate; $\mathrm{N}$, inorganic nitrogen; $\mathrm{Cl}$, chloride; $\mathrm{SO}_{4}$, sulfate; $\mathrm{pH}$, negative log of hydrogen-ion molarity; Cond, specific conductance in microSeimens per centimeter; Svol, sample volume in milliliters; RG ppt, rain gage precipitation depth in millimeters; Sub ppt, sample volume converted to depth substituted for missing weekly RG ppt. Lab types: W, sufficient volume for analysis; WD, dilution necessary to obtain volume for analysis; D, valid dry week; T, valid trace sample with insufficient volume for analysis. Inval codes: b, bulk sample (collector was open continuously); c, contaminated; d, debris; e, extended sampling period greater than 8 days; $h$, handling protocol problems; m, missing data; u, undefined; v, inadequate volume for analysis; z, site operation problems; *, no Inval code assigned. QR (Quality Rating) codes: A, highest quality rating;

B, valid with minor problems; C, invalid. Concentrations in milligrams per liter. Valid dry week samples have no chemical data and have QR code of A. --, no data]

\begin{tabular}{|c|c|c|c|c|c|c|c|c|c|c|c|c|c|c|c|c|c|c|c|}
\hline Site & Date on & Date off & $\mathrm{Ca}$ & Mg & $\mathbf{K}$ & $\mathrm{Na}$ & $\mathrm{NH}_{4}$ & $\mathrm{NO}_{3}$ & $\mathbf{N}$ & Cl & $\mathrm{SO}_{4}$ & pH & Cond & Svol & $\begin{array}{l}\text { RG } \\
\text { ppt }\end{array}$ & $\begin{array}{l}\text { Sub } \\
\text { ppt }\end{array}$ & $\begin{array}{l}\text { Lab } \\
\text { type }\end{array}$ & $\begin{array}{l}\text { Inval } \\
\text { codes }\end{array}$ & $\begin{array}{c}\mathrm{OR} \\
\text { code }\end{array}$ \\
\hline CO89 & $7 / 15 / 2014$ & $7 / 22 / 2014$ & 0.411 & 0.058 & 0.084 & 0.075 & 0.484 & 1.108 & 0.627 & 0.122 & 0.641 & 6.01 & 8 & 931 & 14.22 & 14.22 & $\mathrm{~W}$ & d & B \\
\hline CO89 & $7 / 22 / 2014$ & $7 / 29 / 2014$ & 0.267 & 0.023 & 0.048 & 0.017 & 0.424 & 0.817 & 0.514 & 0.049 & 0.378 & 6.05 & 5.8 & 2075.6 & 30.23 & 30.23 & W & d & B \\
\hline CO89 & $7 / 29 / 2014$ & 8/5/2014 & 0.01 & 0.002 & 0.003 & 0.001 & 0.051 & 0.241 & 0.094 & 0.012 & 0.077 & 5.23 & 3.1 & 4908.2 & 72.9 & 72.9 & W & $*$ & $\mathrm{~A}$ \\
\hline CO89 & $8 / 5 / 2014$ & $8 / 12 / 2014$ & 0.113 & 0.016 & 0.03 & 0.014 & 0.334 & 0.837 & 0.449 & 0.047 & 0.47 & 5.03 & 7.5 & 1013.8 & 13.97 & 13.97 & W & $\mathrm{d}$ & B \\
\hline CO89 & $8 / 12 / 2014$ & $8 / 19 / 2014$ & 0.092 & 0.012 & 0.017 & 0.016 & 0.252 & 0.686 & 0.351 & 0.044 & 0.302 & 5.33 & 4.8 & 836.6 & 11.43 & 11.43 & W & d & B \\
\hline CO89 & $8 / 19 / 2014$ & $8 / 26 / 2014$ & 0.08 & 0.011 & 0.019 & 0.02 & 0.166 & 0.604 & 0.266 & 0.037 & 0.258 & 5.3 & 4.7 & 1294.6 & 21.34 & 21.34 & W & $\mathrm{d}$ & B \\
\hline CO89 & $8 / 26 / 2014$ & $9 / 2 / 2014$ & 0.14 & 0.016 & 0.023 & 0.026 & 0.242 & 0.848 & 0.38 & 0.06 & 0.323 & 5.36 & 5.3 & 1245.2 & 20.83 & 20.83 & W & d & B \\
\hline CO89 & $9 / 2 / 2014$ & $9 / 9 / 2014$ & 0.132 & 0.018 & 0.014 & 0.045 & 0.275 & 0.851 & 0.406 & 0.075 & 0.311 & 5.51 & 5 & 1005.4 & 14.99 & 14.99 & W & d & B \\
\hline CO89 & 9/9/2014 & $9 / 16 / 2014$ & 0.044 & 0.007 & 0.01 & 0.013 & 0.065 & 0.237 & 0.104 & 0.019 & 0.104 & 5.46 & 2.8 & 1603.3 & 26.92 & 26.92 & W & $\mathrm{d}$ & B \\
\hline CO89 & $9 / 16 / 2014$ & $9 / 23 / 2014$ & 0.031 & 0.005 & 0.011 & 0.014 & 0.113 & 0.324 & 0.161 & 0.023 & 0.179 & 5.33 & 3.4 & 1763.9 & 27.43 & 27.43 & W & $\mathrm{d}$ & B \\
\hline CO89 & $9 / 23 / 2014$ & $9 / 30 / 2014$ & 0.045 & 0.006 & 0.007 & 0.009 & 0.129 & 0.278 & 0.163 & 0.016 & 0.218 & 5.45 & 3.1 & 1735.2 & 30.73 & 30.73 & W & $\mathrm{d}$ & B \\
\hline CO98 & $9 / 29 / 2009$ & $10 / 6 / 2009$ & 2.006 & 0.136 & 0.086 & 0.117 & 0.269 & 0.859 & 0.403 & 0.151 & 0.73 & 7.34 & 14.8 & 1051.9 & 27.18 & 27.18 & W & $\mathrm{c}$ & $\mathrm{C}$ \\
\hline CO98 & $10 / 6 / 2009$ & $10 / 13 / 2009$ & 0.335 & 0.051 & 0.028 & 0.131 & 0.242 & 1.091 & 0.435 & 0.188 & 0.627 & 5.64 & 6.5 & 913.6 & 27.18 & 27.18 & W & $*$ & B \\
\hline CO98 & $10 / 13 / 2009$ & $10 / 20 / 2009$ & 0.069 & 0.007 & 0.007 & 0.019 & 0.083 & 0.459 & 0.168 & 0.027 & 0.356 & 5.16 & 5.1 & 1137.1 & 19.05 & 19.05 & W & $*$ & B \\
\hline CO98 & $10 / 20 / 2009$ & $10 / 27 / 2009$ & 0.301 & 0.029 & 0.02 & 0.034 & 0.204 & 1.029 & 0.391 & 0.058 & 0.471 & 5.52 & 5.6 & 751.1 & -- & 10.67 & W & $*$ & B \\
\hline CO98 & $10 / 27 / 2009$ & $11 / 3 / 2009$ & 0.069 & 0.006 & 0.004 & 0.004 & 0.022 & 0.254 & 0.074 & 0.011 & 0.085 & 5.49 & 2.1 & 1344.1 & 40.39 & 40.39 & W & $*$ & B \\
\hline CO98 & $11 / 3 / 2009$ & $11 / 10 / 2009$ & -- & -- & -- & -- & -- & -- & -- & -- & -- & -- & -- & 3.6 & 0.25 & 0.25 & $\mathrm{D}$ & $\mathrm{v}$ & $\mathrm{C}$ \\
\hline CO98 & $11 / 10 / 2009$ & $11 / 17 / 2009$ & 0.236 & 0.017 & 0.014 & 0.017 & 0.158 & 0.654 & 0.271 & 0.035 & 0.422 & 5.75 & 4.2 & 1052.5 & 23.62 & 23.62 & W & $*$ & $\mathrm{~A}$ \\
\hline CO98 & $11 / 17 / 2009$ & $11 / 24 / 2009$ & 0.217 & 0.019 & 0.014 & 0.096 & 0.075 & 0.9 & 0.262 & 0.066 & 0.284 & 5.44 & 4.8 & 266.7 & 15.75 & 15.75 & W & $*$ & A \\
\hline CO98 & $11 / 24 / 2009$ & $12 / 1 / 2009$ & -- & -- & -- & -- & -- & -- & -- & -- & -- & -- & -- & -- & -- & 0 & $\mathrm{D}$ & $*$ & B \\
\hline CO98 & $12 / 1 / 2009$ & $12 / 8 / 2009$ & 0.072 & 0.007 & 0.009 & 0.03 & 0.079 & 0.526 & 0.18 & 0.037 & 0.093 & 5.46 & 3.1 & 1400.2 & 33.78 & 33.78 & W & $\mathrm{u}$ & $\mathrm{C}$ \\
\hline CO98 & $12 / 8 / 2009$ & $12 / 15 / 2009$ & -- & -- & -- & -- & -- & -- & -- & -- & -- & -- & -- & 0 & 49.78 & 49.78 & $\mathrm{D}$ & $\mathrm{vb}$ & $\mathrm{C}$ \\
\hline CO98 & $12 / 15 / 2009$ & $12 / 22 / 2009$ & -- & -- & -- & -- & -- & -- & -- & -- & -- & -- & -- & 0.6 & 6.1 & 6.1 & $\mathrm{D}$ & $\mathrm{v}$ & $\mathrm{C}$ \\
\hline CO98 & $12 / 22 / 2009$ & $12 / 29 / 2009$ & 0.043 & 0.004 & 0.006 & 0.01 & 0.141 & 0.581 & 0.241 & 0.019 & 0.19 & 5.42 & 3.9 & 375.2 & 27.69 & 27.69 & W & $\mathrm{b}$ & $\mathrm{C}$ \\
\hline CO98 & $12 / 29 / 2009$ & $1 / 5 / 2010$ & -- & -- & -- & -- & -- & -- & -- & -- & -- & 4.99 & 6.2 & 24.2 & 20.07 & 20.07 & $\mathrm{~T}$ & $\mathrm{vu}$ & $\mathrm{C}$ \\
\hline CO98 & $1 / 5 / 2010$ & $1 / 12 / 2010$ & -- & -- & -- & -- & -- & -- & -- & -- & -- & -- & -- & 0 & 14.22 & 14.22 & $\mathrm{D}$ & $\mathrm{vb}$ & $\mathrm{C}$ \\
\hline CO98 & $1 / 12 / 2010$ & $1 / 19 / 2010$ & -- & -- & -- & -- & -- & -- & -- & -- & -- & -- & -- & 0 & 0.51 & 0.51 & $\mathrm{D}$ & $\mathrm{v}$ & $\mathrm{C}$ \\
\hline CO98 & $1 / 19 / 2010$ & $1 / 26 / 2010$ & 0.097 & 0.011 & 0.03 & 0.011 & 0.049 & 0.452 & 0.14 & 0.036 & 0.139 & 5.19 & 4.3 & 36 & 21.34 & 21.34 & WD & $*$ & $\mathrm{~B}$ \\
\hline CO98 & $1 / 26 / 2010$ & $2 / 2 / 2010$ & 0.037 & 0.003 & 0.004 & 0.012 & 0.138 & 0.871 & 0.304 & 0.032 & 0.097 & 5.12 & 6 & 326.5 & 12.95 & 12.95 & $\mathrm{~W}$ & $*$ & $\mathrm{~A}$ \\
\hline CO98 & $2 / 2 / 2010$ & 2/9/2010 & 0.046 & 0.006 & 0.004 & 0.018 & 0.23 & 1.339 & 0.481 & 0.043 & 0.436 & 4.77 & 9.9 & 172.2 & 8.89 & 8.89 & W & $*$ & A \\
\hline CO98 & $2 / 9 / 2010$ & $2 / 16 / 2010$ & 0.091 & 0.009 & 0.005 & 0.019 & 0.089 & 0.496 & 0.181 & 0.029 & 0.325 & 5.2 & 4.6 & 103.3 & 26.92 & 26.92 & W & $*$ & A \\
\hline CO98 & $2 / 16 / 2010$ & $2 / 23 / 2010$ & 0.098 & 0.011 & 0.01 & 0.035 & 0.073 & 0.473 & 0.164 & 0.049 & 0.184 & 5.45 & 3.4 & 1196.1 & 37.34 & 37.34 & W & $*$ & A \\
\hline CO98 & $2 / 23 / 2010$ & $3 / 2 / 2010$ & 0.03 & 0.002 & 0.002 & 0.004 & 0.047 & 1.538 & 0.384 & 0.053 & 0.103 & 4.66 & 11.7 & 447.7 & 8.64 & 8.64 & $\mathrm{~W}$ & $*$ & $\mathrm{~A}$ \\
\hline
\end{tabular}


[Date on, start of weekly sample collection; Date off, end of weekly sample collection; Ca, calcium; $\mathrm{Mg}$, magnesium; $\mathrm{K}$, potassium; $\mathrm{Na}$, sodium; $\mathrm{NH}_{4}$, ammonium; $\mathrm{NO}_{3}$, nitrate; $\mathrm{N}$, inorganic nitrogen; $\mathrm{Cl}$, chloride; $\mathrm{SO}_{4}$, sulfate; $\mathrm{pH}$, negative log of hydrogen-ion molarity; Cond, specific conductance in microSeimens per centimeter; Svol, sample volume in milliliters; RG ppt, rain gage precipitation depth in millimeters; Sub ppt, sample volume converted to depth substituted for missing weekly RG ppt. Lab types: W, sufficient volume for analysis; WD, dilution necessary to obtain volume for analysis; D, valid dry week; T, valid trace sample with insufficient volume for analysis. Inval codes: b, bulk sample (collector was open continuously); c, contaminated; d, debris; e, extended sampling period greater than 8 days; h, handling protocol problems; m, missing data; u, undefined; v, inadequate volume for analysis; z, site operation problems; *, no Inval code assigned. QR (Quality Rating) codes: A, highest quality rating; B, valid with minor problems; C, invalid. Concentrations in milligrams per liter. Valid dry week samples have no chemical data and have QR code of A. --, no data]

\begin{tabular}{|c|c|c|c|c|c|c|c|c|c|c|c|c|c|c|c|c|c|c|c|}
\hline Site & Date on & Date off & $\mathrm{Ca}$ & Mg & $\mathbf{K}$ & $\mathrm{Na}$ & $\mathrm{NH}_{4}$ & $\mathrm{NO}_{3}$ & $\mathbf{N}$ & Cl & $\mathrm{SO}_{4}$ & $\mathrm{pH}$ & Cond & Svol & $\begin{array}{l}\text { RG } \\
\text { ppt }\end{array}$ & $\begin{array}{l}\text { Sub } \\
\text { ppt }\end{array}$ & $\begin{array}{l}\text { Lab } \\
\text { type }\end{array}$ & $\begin{array}{l}\text { Inval } \\
\text { codes }\end{array}$ & $\begin{array}{c}\mathrm{OR} \\
\text { code }\end{array}$ \\
\hline CO98 & $3 / 2 / 2010$ & $3 / 9 / 2010$ & 0.064 & 0.007 & 0.006 & 0.018 & 0.116 & 0.441 & 0.19 & 0.035 & 0.364 & 5.13 & 5 & 115.3 & 23.37 & 23.37 & $\mathrm{~W}$ & $*$ & A \\
\hline CO98 & $3 / 9 / 2010$ & $3 / 16 / 2010$ & 0.095 & 0.008 & 0.007 & 0.014 & 0.854 & 1.202 & 0.936 & 0.027 & 0.821 & 6.09 & 8.1 & 432.8 & 10.92 & 10.92 & W & $*$ & B \\
\hline CO98 & $3 / 16 / 2010$ & $3 / 23 / 2010$ & 0.097 & 0.009 & 0.006 & 0.017 & 0.105 & 0.548 & 0.205 & 0.026 & 0.129 & 5.49 & 3.2 & 1177.4 & 29.72 & 29.72 & W & $*$ & B \\
\hline CO98 & $3 / 23 / 2010$ & $3 / 30 / 2010$ & 0.077 & 0.008 & 0.004 & 0.018 & 0.162 & 0.249 & 0.182 & 0.018 & 0.137 & 5.84 & 2.4 & 1307.5 & 30.99 & 30.99 & W & $*$ & B \\
\hline CO98 & $3 / 30 / 2010$ & 4/6/2010 & 1.19 & 0.068 & 0.041 & 0.038 & 0.109 & 0.356 & 0.165 & 0.039 & 0.377 & 6.66 & 8.6 & 1151 & 81.03 & 81.03 & W & $*$ & B \\
\hline CO98 & $4 / 6 / 2010$ & $4 / 13 / 2010$ & -- & -- & -- & -- & -- & -- & -- & -- & -- & -- & -- & 319.2 & 16.51 & 16.51 & $\mathrm{~W}$ & $\mathrm{c}$ & $\mathrm{C}$ \\
\hline $\mathrm{CO} 98$ & $4 / 13 / 2010$ & $4 / 20 / 2010$ & 0.205 & 0.026 & 0.025 & 0.043 & 0.143 & 0.83 & 0.299 & 0.073 & 0.448 & 5.15 & 6.3 & 187.7 & 5.59 & 5.59 & W & $*$ & A \\
\hline CO98 & $4 / 20 / 2010$ & $4 / 27 / 2010$ & -- & -- & -- & -- & -- & -- & -- & -- & -- & -- & -- & 2482.3 & 67.31 & 67.31 & W & $\mathrm{u}$ & $\mathrm{C}$ \\
\hline CO98 & $5 / 4 / 2010$ & $5 / 11 / 2010$ & -- & -- & -- & -- & -- & -- & -- & -- & -- & -- & -- & 752.2 & 25.15 & 25.15 & W & $\mathrm{c}$ & $\mathrm{C}$ \\
\hline CO98 & $5 / 11 / 2010$ & $5 / 18 / 2010$ & 0.884 & 0.046 & 0.048 & 0.043 & 0.079 & 0.431 & 0.159 & 0.038 & 0.327 & 6.53 & 6.7 & 3431.2 & 72.64 & 72.64 & W & $*$ & B \\
\hline CO98 & $6 / 8 / 2010$ & $6 / 15 / 2010$ & 0.188 & 0.017 & 0.029 & 0.033 & 0.149 & 0.42 & 0.211 & 0.055 & 0.264 & 5.72 & 3.7 & 3618 & 55.12 & 55.12 & W & $*$ & B \\
\hline CO98 & $6 / 29 / 2010$ & 7/6/2010 & 0.232 & 0.023 & 0.067 & 0.017 & 0.387 & 1.333 & 0.602 & 0.065 & 0.575 & 5.27 & 7.9 & 601 & 9.4 & 9.4 & W & $*$ & B \\
\hline CO98 & $7 / 6 / 2010$ & $7 / 13 / 2010$ & 0.176 & 0.026 & 0.025 & 0.069 & 0.202 & 0.852 & 0.35 & 0.115 & 0.464 & 5.17 & 6.6 & 2065.1 & 31.75 & 31.75 & W & $*$ & B \\
\hline CO98 & $7 / 13 / 2010$ & $7 / 20 / 2010$ & 0.423 & 0.05 & 0.049 & 0.075 & 0.466 & 1.326 & 0.662 & 0.141 & 0.705 & 5.98 & 8.2 & 818.2 & 11.68 & 11.68 & W & $*$ & B \\
\hline CO98 & $7 / 20 / 2010$ & $7 / 27 / 2010$ & 0.282 & 0.031 & 0.04 & 0.045 & 0.292 & 1.28 & 0.516 & 0.086 & 0.514 & 5.36 & 7.1 & 798.2 & 12.19 & 12.19 & W & $*$ & B \\
\hline CO98 & $7 / 27 / 2010$ & $8 / 3 / 2010$ & 0.064 & 0.007 & 0.008 & 0.011 & 0.166 & 0.636 & 0.273 & 0.028 & 0.281 & 5.07 & 6.3 & 4675.2 & 70.87 & 70.87 & W & $*$ & B \\
\hline CO98 & $8 / 3 / 2010$ & $8 / 10 / 2010$ & 0.055 & 0.007 & 0.01 & 0.015 & 0.199 & 0.84 & 0.345 & 0.046 & 0.351 & 4.95 & 7.2 & 2205 & 32.26 & 32.26 & W & $*$ & B \\
\hline CO98 & $8 / 10 / 2010$ & $8 / 17 / 2010$ & 0.06 & 0.008 & 0.012 & 0.019 & 0.069 & 0.324 & 0.127 & 0.039 & 0.28 & 5.14 & 4 & 526.2 & 7.87 & 7.87 & W & $*$ & B \\
\hline CO98 & $8 / 17 / 2010$ & $8 / 24 / 2010$ & 0.077 & 0.009 & 0.008 & 0.015 & 0.085 & 0.395 & 0.155 & 0.031 & 0.21 & 5.28 & 3.8 & 565.7 & 9.14 & 9.14 & W & $*$ & B \\
\hline CO98 & $8 / 24 / 2010$ & $8 / 31 / 2010$ & 0.09 & 0.008 & 0.009 & 0.008 & 0.091 & 0.725 & 0.235 & 0.034 & 0.375 & 4.97 & 6.7 & 400.6 & 5.84 & 5.84 & W & $*$ & B \\
\hline CO98 & 9/7/2010 & $9 / 14 / 2010$ & 0.02 & 0.002 & 0.003 & 0.007 & 0.06 & 0.198 & 0.091 & 0.018 & 0.121 & 5.33 & 2.7 & 746.5 & 11.18 & 11.18 & W & $*$ & A \\
\hline CO98 & $9 / 21 / 2010$ & $9 / 28 / 2010$ & 0.058 & 0.006 & 0.006 & 0.016 & 0.064 & 0.3 & 0.118 & 0.031 & 0.15 & 5.31 & 3.1 & 1014.9 & 15.49 & 15.49 & W & $*$ & B \\
\hline $\mathrm{CO} 98$ & $10 / 5 / 2010$ & $10 / 12 / 2010$ & 0.087 & 0.008 & 0.015 & 0.013 & 0.206 & 0.469 & 0.266 & 0.028 & 0.483 & 5.35 & 4.9 & 1699.9 & 32 & 32 & W & $*$ & B \\
\hline CO98 & $10 / 12 / 2010$ & $10 / 19 / 2010$ & 0.127 & 0.012 & 0.009 & 0.014 & 0.212 & 0.685 & 0.32 & 0.028 & 0.491 & 5.22 & 5.4 & 841.8 & 14.22 & 14.22 & W & $*$ & B \\
\hline CO98 & $10 / 19 / 2010$ & $10 / 26 / 2010$ & 0.012 & 0.001 & 0.003 & 0.002 & 0.036 & 0.102 & 0.051 & 0.011 & 0.052 & 5.42 & 2 & 2916 & -- & 42.95 & W & $*$ & B \\
\hline CO98 & $11 / 9 / 2010$ & $11 / 16 / 2010$ & -- & -- & -- & -- & -- & -- & -- & -- & -- & -- & -- & 100.7 & 43.69 & 43.69 & W & $\mathrm{b}$ & $\mathrm{C}$ \\
\hline CO98 & $11 / 16 / 2010$ & $11 / 23 / 2010$ & 0.035 & 0.004 & 0.004 & 0.004 & 0.022 & 0.135 & 0.048 & 0.013 & 0.094 & 5.47 & 2.3 & 297.1 & 47.5 & 47.5 & W & $*$ & B \\
\hline CO98 & $11 / 23 / 2010$ & $11 / 30 / 2010$ & 0.06 & 0.006 & 0.008 & 0.013 & 0.025 & 0.37 & 0.103 & 0.026 & 0.098 & 5.13 & 3.4 & 88.7 & 20.32 & 20.32 & W & $*$ & A \\
\hline CO98 & $12 / 14 / 2010$ & $12 / 21 / 2010$ & -- & -- & -- & -- & -- & -- & -- & -- & -- & -- & -- & 686.2 & 122.43 & 122.43 & W & $\mathrm{b}$ & $\mathrm{C}$ \\
\hline CO98 & $12 / 21 / 2010$ & $12 / 28 / 2010$ & -- & -- & -- & -- & -- & -- & -- & -- & -- & -- & -- & 97 & 17.02 & 17.02 & W & $\mathrm{b}$ & $\mathrm{C}$ \\
\hline CO98 & $12 / 28 / 2010$ & $1 / 4 / 2011$ & -- & -- & -- & -- & -- & -- & -- & -- & -- & -- & -- & 146.9 & -- & 2.16 & W & $\mathrm{u}$ & $\mathrm{C}$ \\
\hline CO98 & 1/4/2011 & $1 / 11 / 2011$ & 0.011 & 0.001 & 0.001 & 0.003 & 0.08 & 0.492 & 0.173 & 0.017 & 0.195 & 5.12 & 4.8 & 414 & 14.73 & 14.73 & W & $*$ & A \\
\hline CO98 & $1 / 11 / 2011$ & $1 / 18 / 2011$ & 0.02 & 0.002 & 0.003 & 0.005 & 0.032 & 0.114 & 0.051 & 0.012 & 0.077 & 5.38 & 2.4 & 419.3 & 61.47 & 61.47 & W & $*$ & A \\
\hline
\end{tabular}


Table 1-1. Wet-deposition sample analysis data for colocated sites C089 and C098, water years 2010-14.-Continued

[Date on, start of weekly sample collection; Date off, end of weekly sample collection; $\mathrm{Ca}$, calcium; $\mathrm{Mg}$, magnesium; $\mathrm{K}$, potassium; $\mathrm{Na}$, sodium; $\mathrm{NH}_{4}$, ammonium; $\mathrm{NO}$, nitrate; $\mathrm{N}$, inorganic nitrogen; $\mathrm{Cl}$, chloride; $\mathrm{SO}_{4}$, sulfate; $\mathrm{pH}$, negative log of hydrogen-ion molarity; Cond, specific conductance in microSeimens per centimeter; Svol, sample volume in milliliters; RG ppt, rain gage precipitation depth in millimeters; Sub ppt, sample volume converted to depth substituted for missing weekly RG ppt. Lab types: W, sufficient volume for analysis; WD, dilution necessary to obtain volume for analysis; D, valid dry week; T, valid trace sample with insufficient volume for analysis. Inval codes: b, bulk sample (collector was open continuously); c, contaminated; d, debris; e, extended sampling period greater than 8 days; h, handling protocol problems; m, missing data; u, undefined; $v$, inadequate volume for analysis; $\mathrm{z}$, site operation problems; *, no Inval code assigned. QR (Quality Rating) codes: A, highest quality rating;

B, valid with minor problems; C, invalid. Concentrations in milligrams per liter. Valid dry week samples have no chemical data and have QR code of A. --, no data]

\begin{tabular}{|c|c|c|c|c|c|c|c|c|c|c|c|c|c|c|c|c|c|c|c|}
\hline Site & Date on & Date off & $\mathrm{Ca}$ & Mg & $\mathbf{K}$ & $\mathrm{Na}$ & $\mathrm{NH}_{4}$ & $\mathrm{NO}_{3}$ & $\mathbf{N}$ & Cl & $\mathrm{SO}_{4}$ & pH & Cond & Svol & $\begin{array}{l}\text { RG } \\
\text { ppt }\end{array}$ & $\begin{array}{l}\text { Sub } \\
\text { ppt }\end{array}$ & $\begin{array}{l}\text { Lab } \\
\text { type }\end{array}$ & $\begin{array}{l}\text { Inval } \\
\text { codes }\end{array}$ & $\begin{array}{c}\mathrm{OR} \\
\text { code }\end{array}$ \\
\hline CO98 & $1 / 18 / 2011$ & $1 / 25 / 2011$ & -- & -- & -- & -- & -- & -- & -- & -- & -- & -- & -- & 459.6 & -- & 6.77 & $\mathrm{~W}$ & $\mathrm{u}$ & $\mathrm{C}$ \\
\hline CO98 & $1 / 25 / 2011$ & $2 / 2 / 2011$ & 0.044 & 0.006 & 0.006 & 0.012 & 0.068 & 0.606 & 0.19 & 0.032 & 0.193 & 5.04 & 5.3 & 180.3 & 4.57 & 4.57 & W & $*$ & B \\
\hline CO98 & $2 / 2 / 2011$ & $2 / 8 / 2011$ & 0.011 & 0.001 & 0.001 & 0.002 & 0.025 & 0.204 & 0.066 & 0.027 & 0.099 & 5.4 & 2.6 & 997.5 & -- & 14.69 & $\mathrm{~W}$ & $*$ & B \\
\hline CO98 & $2 / 8 / 2011$ & $2 / 15 / 2011$ & -- & -- & -- & -- & -- & -- & -- & -- & -- & -- & -- & 0.5 & 11.94 & 11.94 & $\mathrm{~T}$ & $\mathrm{v}$ & $\mathrm{C}$ \\
\hline CO98 & $2 / 15 / 2011$ & $2 / 22 / 2011$ & -- & -- & -- & -- & -- & -- & -- & -- & -- & -- & -- & 525.6 & 37.85 & 37.85 & W & $\mathrm{u}$ & $\mathrm{C}$ \\
\hline CO98 & $2 / 22 / 2011$ & $3 / 1 / 2011$ & 0.086 & 0.018 & 0.009 & 0.023 & 0.127 & 0.885 & 0.299 & 0.067 & 0.124 & 5.19 & 4.8 & 445.4 & 67.31 & 67.31 & W & $*$ & B \\
\hline CO98 & $3 / 1 / 2011$ & $3 / 8 / 2011$ & 0.09 & 0.011 & 0.01 & 0.018 & 0.094 & 0.48 & 0.182 & 0.026 & 0.31 & 5.21 & 4.3 & 563.5 & 33.27 & 33.27 & W & $*$ & B \\
\hline CO98 & $3 / 8 / 2011$ & $3 / 15 / 2011$ & 0.099 & 0.013 & 0.007 & 0.026 & 0.13 & 0.573 & 0.231 & 0.03 & 0.215 & 5.42 & 3.5 & 639 & 37.08 & 37.08 & W & $*$ & A \\
\hline CO98 & $3 / 15 / 2011$ & $3 / 22 / 2011$ & 0.683 & 0.045 & 0.042 & 0.069 & 0.056 & 0.436 & 0.142 & 0.049 & 0.391 & 6.46 & 5.4 & 1285 & 48.26 & 48.26 & $\mathrm{~W}$ & $*$ & B \\
\hline CO98 & $3 / 22 / 2011$ & $3 / 29 / 2011$ & 0.137 & 0.017 & 0.007 & 0.022 & 0.058 & 0.385 & 0.132 & 0.029 & 0.257 & 5.47 & 3.1 & 1033.6 & 54.86 & 54.86 & W & $*$ & A \\
\hline CO98 & $3 / 29 / 2011$ & 4/5/2011 & 0.418 & 0.042 & 0.057 & 0.034 & 0.138 & 0.772 & 0.282 & 0.069 & 0.469 & 5.97 & 5.1 & 343.4 & 82.8 & 82.8 & W & $*$ & B \\
\hline CO98 & $4 / 5 / 2011$ & $4 / 12 / 2011$ & 0.181 & 0.018 & 0.012 & 0.037 & 0.134 & 0.505 & 0.218 & 0.046 & 0.433 & 5.53 & 4.2 & 419.3 & 44.7 & 44.7 & W & $*$ & A \\
\hline CO98 & $4 / 12 / 2011$ & $4 / 19 / 2011$ & 0.145 & 0.019 & 0.02 & 0.02 & 0.229 & 0.567 & 0.306 & 0.033 & 0.417 & 5.6 & 4.3 & 3103.8 & -- & 45.72 & W & $*$ & B \\
\hline CO98 & $4 / 19 / 2011$ & $4 / 26 / 2011$ & -- & -- & -- & -- & -- & -- & -- & -- & -- & -- & -- & 3841.9 & -- & 56.59 & W & $\mathrm{u}$ & $\mathrm{C}$ \\
\hline CO98 & $4 / 26 / 2011$ & $5 / 3 / 2011$ & 0.207 & 0.026 & 0.014 & 0.055 & 0.078 & 0.37 & 0.144 & 0.056 & 0.321 & 5.71 & 3.4 & 577 & -- & 8.5 & W & $*$ & B \\
\hline CO98 & $5 / 3 / 2011$ & $5 / 10 / 2011$ & 1.332 & 0.126 & 0.044 & 0.126 & 0.279 & 2.196 & 0.713 & 0.159 & 1.057 & 6.52 & 12.5 & 81.1 & 34.54 & 34.54 & W & $*$ & A \\
\hline CO98 & $5 / 10 / 2011$ & $5 / 17 / 2011$ & 0.228 & 0.032 & 0.013 & 0.034 & 0.158 & 0.276 & 0.185 & 0.046 & 0.321 & 6.03 & 3.5 & 2578.4 & 52.83 & 52.83 & W & $*$ & B \\
\hline CO98 & $5 / 17 / 2011$ & $5 / 24 / 2011$ & 0.077 & 0.008 & 0.006 & 0.013 & 0.058 & 0.417 & 0.139 & 0.025 & 0.153 & 5.29 & 3.4 & 3907.3 & 0 & 57.55 & W & $*$ & B \\
\hline CO98 & $5 / 24 / 2011$ & $5 / 31 / 2011$ & -- & -- & -- & -- & -- & -- & -- & -- & -- & -- & -- & 1341.9 & 46.48 & 46.48 & $\mathrm{~W}$ & $\mathrm{c}$ & $\mathrm{C}$ \\
\hline CO98 & $5 / 31 / 2011$ & $6 / 7 / 2011$ & -- & -- & -- & -- & -- & -- & -- & -- & -- & -- & -- & & & 0 & $\mathrm{~T}$ & $*$ & B \\
\hline CO98 & 6/7/2011 & $6 / 14 / 2011$ & -- & -- & -- & -- & -- & -- & -- & -- & -- & -- & -- & 81.1 & 1.27 & 1.27 & W & $\mathrm{c}$ & $\mathrm{C}$ \\
\hline CO98 & $6 / 14 / 2011$ & $6 / 21 / 2011$ & 0.223 & 0.025 & 0.043 & 0.033 & 0.191 & 0.712 & 0.309 & 0.061 & 0.554 & 5.48 & 5.2 & 2651.7 & 43.94 & 43.94 & $\mathrm{~W}$ & $*$ & B \\
\hline CO98 & $6 / 21 / 2011$ & $6 / 28 / 2011$ & 0.717 & 0.105 & 0.255 & 0.097 & 0.266 & 1.731 & 0.598 & 0.18 & 1.127 & 5.58 & 11.2 & 35 & 0.25 & 0.25 & WD & $*$ & B \\
\hline CO98 & $6 / 28 / 2011$ & 7/5/2011 & -- & -- & -- & -- & -- & -- & -- & -- & -- & -- & -- & 1658.7 & 23.11 & 23.11 & $\mathrm{~W}$ & $\mathrm{c}$ & $\mathrm{C}$ \\
\hline CO98 & $7 / 5 / 2011$ & $7 / 12 / 2011$ & 0.085 & 0.011 & 0.036 & 0.017 & 0.222 & 0.704 & 0.332 & 0.041 & 0.415 & 5.17 & 5.9 & 1333.8 & 20.57 & 20.57 & W & $*$ & B \\
\hline CO98 & $7 / 12 / 2011$ & $7 / 19 / 2011$ & 0.194 & 0.015 & 0.019 & 0.037 & 0.333 & 1.357 & 0.566 & 0.05 & 0.644 & 5 & 8.5 & 2629.1 & 38.1 & 38.1 & W & $*$ & B \\
\hline CO98 & $7 / 19 / 2011$ & $7 / 26 / 2011$ & 0.417 & 0.05 & 0.044 & 0.11 & 0.425 & 2.518 & 0.899 & 0.236 & 1.306 & 4.67 & 17.8 & 61.6 & 0.51 & 0.51 & $\mathrm{~W}$ & $*$ & B \\
\hline CO98 & $7 / 26 / 2011$ & $8 / 2 / 2011$ & 0.107 & 0.013 & 0.016 & 0.021 & 0.353 & 1.299 & 0.568 & 0.048 & 0.653 & 4.85 & 9.6 & 741.2 & 10.41 & 10.41 & W & $*$ & B \\
\hline CO98 & $8 / 2 / 2011$ & 8/9/2011 & 0.133 & 0.022 & 0.033 & 0.039 & 0.272 & 2.022 & 0.668 & 0.115 & 0.589 & 4.56 & 14.3 & 164.3 & 2.29 & 2.29 & W & $*$ & B \\
\hline CO98 & 8/9/2011 & $8 / 16 / 2011$ & 0.52 & 0.063 & 0.053 & 0.064 & 0.224 & 1.592 & 0.534 & 0.107 & 0.793 & 5.51 & 8.5 & 77.8 & 1.02 & 1.02 & W & $*$ & B \\
\hline CO98 & $8 / 16 / 2011$ & $8 / 23 / 2011$ & 0.272 & 0.036 & 0.021 & 0.052 & 0.364 & 2.806 & 0.917 & 0.15 & 0.915 & 4.55 & 17.5 & 367.8 & 4.57 & 4.57 & W & $*$ & B \\
\hline CO98 & $8 / 23 / 2011$ & $8 / 30 / 2011$ & 0.167 & 0.02 & 0.018 & 0.022 & 0.349 & 1.646 & 0.643 & 0.068 & 0.554 & 4.87 & 10.5 & 1029.4 & 14.48 & 14.48 & W & $*$ & B \\
\hline CO98 & $8 / 30 / 2011$ & 9/6/2011 & 0.225 & 0.03 & 0.048 & 0.046 & 0.342 & 1.13 & 0.521 & 0.097 & 0.589 & 5.4 & 6.9 & 865.2 & 11.68 & 11.68 & W & $*$ & B \\
\hline
\end{tabular}


[Date on, start of weekly sample collection; Date off, end of weekly sample collection; Ca, calcium; $\mathrm{Mg}$, magnesium; $\mathrm{K}$, potassium; $\mathrm{Na}$, sodium; $\mathrm{NH}_{4}$, ammonium; $\mathrm{NO}_{3}$, nitrate; $\mathrm{N}$, inorganic nitrogen; $\mathrm{Cl}$, chloride; $\mathrm{SO}_{4}$, sulfate; $\mathrm{pH}$, negative log of hydrogen-ion molarity; Cond, specific conductance in microSeimens per centimeter; Svol, sample volume in milliliters; RG ppt, rain gage precipitation depth in millimeters; Sub ppt, sample volume converted to depth substituted for missing weekly RG ppt. Lab types: W, sufficient volume for analysis; WD, dilution necessary to obtain volume for analysis; D, valid dry week; T, valid trace sample with insufficient volume for analysis. Inval codes: b, bulk sample (collector was open continuously); c, contaminated; d, debris; e, extended sampling period greater than 8 days; $h$, handling protocol problems; m, missing data; u, undefined; v, inadequate volume for analysis; z, site operation problems; *, no Inval code assigned. QR (Quality Rating) codes: A, highest quality rating; $\mathrm{B}$, valid with minor problems; $\mathrm{C}$, invalid. Concentrations in milligrams per liter. Valid dry week samples have no chemical data and have QR code of A. --, no data]

\begin{tabular}{|c|c|c|c|c|c|c|c|c|c|c|c|c|c|c|c|c|c|c|c|}
\hline Site & Date on & Date off & $\mathrm{Ca}$ & Mg & K & $\mathrm{Na}$ & $\mathrm{NH}_{4}$ & $\mathrm{NO}_{3}$ & $\mathbf{N}$ & Cl & $\mathrm{SO}_{4}$ & $\mathrm{pH}$ & Cond & Svol & $\begin{array}{l}\text { RG } \\
\text { ppt }\end{array}$ & $\begin{array}{l}\text { Sub } \\
\text { ppt }\end{array}$ & $\begin{array}{l}\text { Lab } \\
\text { type }\end{array}$ & $\begin{array}{l}\text { Inval } \\
\text { codes }\end{array}$ & $\begin{array}{c}\text { OR } \\
\text { code }\end{array}$ \\
\hline CO98 & $9 / 6 / 2011$ & $9 / 13 / 2011$ & 0.01 & 0.001 & 0.002 & 0.003 & 0.034 & 0.278 & 0.089 & 0.008 & 0.142 & 5.02 & 3.8 & 2126.7 & 33.02 & 33.02 & W & $*$ & B \\
\hline $\mathrm{CO} 98$ & $9 / 13 / 2011$ & $9 / 20 / 2011$ & 0.011 & 0.002 & 0.003 & 0.004 & 0.05 & 0.315 & 0.11 & 0.019 & 0.149 & 5.09 & 3.8 & 2275.3 & 36.07 & 36.07 & W & $*$ & B \\
\hline CO98 & $9 / 20 / 2011$ & $9 / 27 / 2011$ & 0.37 & 0.037 & 0.038 & 0.034 & 0.532 & 1.162 & 0.676 & 0.057 & 0.664 & 6.24 & 7.6 & 103.1 & 1.52 & 1.52 & W & $*$ & B \\
\hline CO98 & $9 / 27 / 2011$ & $10 / 4 / 2011$ & -- & -- & -- & -- & -- & -- & -- & -- & -- & -- & -- & 0.1 & 3.05 & 3.05 & $\mathrm{~T}$ & $\mathrm{v}$ & $\mathrm{C}$ \\
\hline CO98 & $10 / 4 / 2011$ & $10 / 11 / 2011$ & 0.073 & 0.008 & 0.036 & 0.005 & 0.081 & 0.455 & 0.166 & 0.023 & 0.17 & 5.25 & 3.9 & 1000.5 & 23.11 & 23.11 & W & $*$ & B \\
\hline CO98 & $10 / 11 / 2011$ & $10 / 18 / 2011$ & 0.161 & 0.02 & 0.018 & 0.014 & 0.078 & 0.777 & 0.236 & 0.038 & 0.31 & 5.02 & 5.5 & 827.7 & 25.91 & 25.91 & W & $*$ & B \\
\hline CO98 & $10 / 18 / 2011$ & $10 / 25 / 2011$ & 0.735 & 0.085 & 0.049 & 0.097 & 0.735 & 3.21 & 1.297 & 0.133 & 1.157 & 5.45 & 14.8 & 44 & 1.52 & 1.52 & W & $*$ & A \\
\hline CO98 & $10 / 25 / 2011$ & 11/1/2011 & 0.02 & 0.004 & 0.003 & 0.003 & 0.053 & 0.133 & 0.071 & 0.005 & 0.116 & 5.31 & 2.3 & 1891.4 & 23.62 & 23.62 & W & $*$ & A \\
\hline $\mathrm{CO} 98$ & $11 / 1 / 2011$ & $11 / 8 / 2011$ & 0.061 & 0.007 & 0.006 & 0.012 & 0.154 & 0.529 & 0.239 & 0.014 & 0.185 & 5.31 & 4.1 & 1438.9 & 37.34 & 37.34 & W & $*$ & A \\
\hline $\mathrm{CO} 98$ & $11 / 8 / 2011$ & $11 / 15 / 2011$ & 0.366 & 0.075 & 0.177 & 0.082 & 0.004 & 0.175 & 0.043 & 0.067 & 0.507 & 5.84 & 4.8 & 74.1 & 39.37 & 39.37 & W & $*$ & B \\
\hline CO98 & $11 / 15 / 2011$ & $11 / 22 / 2011$ & 0.168 & 0.017 & 0.013 & 0.066 & 0.119 & 0.499 & 0.205 & 0.061 & 0.33 & 5.73 & 3.7 & 203.9 & 34.04 & 34.04 & W & $*$ & A \\
\hline CO98 & $11 / 22 / 2011$ & $11 / 29 / 2011$ & 0.094 & 0.012 & 0.015 & 0.015 & 0.169 & 0.28 & 0.195 & 0.023 & 0.271 & 5.56 & 3.6 & 149 & 10.92 & 10.92 & W & $*$ & A \\
\hline CO98 & $11 / 29 / 2011$ & $12 / 6 / 2011$ & 0.063 & 0.005 & 0.005 & 0.007 & 0.102 & 0.652 & 0.227 & 0.017 & 0.095 & 5.17 & 4.3 & 1186.5 & 30.48 & 30.48 & W & $*$ & A \\
\hline $\mathrm{CO} 98$ & $12 / 6 / 2011$ & $12 / 13 / 2011$ & 0.074 & 0.011 & 0.008 & 0.014 & 0.123 & 0.37 & 0.179 & 0.047 & 0.272 & 4.92 & 6.2 & 32.7 & 1.78 & 1.78 & WD & $*$ & B \\
\hline CO98 & $12 / 13 / 2011$ & $12 / 20 / 2011$ & -- & -- & -- & -- & -- & -- & -- & -- & -- & -- & -- & 3.7 & 1.02 & 1.02 & $\mathrm{~T}$ & $\mathrm{v}$ & $\mathrm{C}$ \\
\hline CO98 & $12 / 20 / 2011$ & $12 / 27 / 2011$ & 0.009 & 0.001 & 0.002 & 0.006 & 0.052 & 0.32 & 0.113 & 0.011 & 0.06 & 5.35 & 2.7 & 968.5 & 23.62 & 23.62 & W & $*$ & A \\
\hline CO98 & $12 / 27 / 2011$ & $1 / 3 / 2012$ & 0.339 & 0.039 & 0.028 & 0.115 & 0.103 & 0.347 & 0.159 & 0.099 & 0.415 & 6.25 & 4.4 & 87.9 & 15.24 & 15.24 & W & $*$ & B \\
\hline CO98 & $1 / 3 / 2012$ & $1 / 10 / 2012$ & 0.012 & 0.002 & 0.002 & 0.003 & 0.036 & 0.229 & 0.08 & 0.005 & 0.055 & 5.27 & 2.9 & 731.5 & 16.51 & 16.51 & W & $*$ & A \\
\hline CO98 & $1 / 10 / 2012$ & $1 / 17 / 2012$ & 0.076 & 0.009 & 0.006 & 0.021 & 0.101 & 0.489 & 0.189 & 0.023 & 0.201 & 5.21 & 3.8 & 307.8 & 19.05 & 19.05 & W & $*$ & A \\
\hline CO98 & $1 / 17 / 2012$ & $1 / 24 / 2012$ & 0.127 & 0.022 & 0.038 & 0.041 & 0.087 & 0.293 & 0.134 & 0.058 & 0.236 & 5.44 & 3.9 & 161.2 & 57.91 & 57.91 & W & $*$ & B \\
\hline $\mathrm{CO} 98$ & $1 / 24 / 2012$ & $1 / 31 / 2012$ & 0.08 & 0.008 & 0.008 & 0.02 & 0.118 & 0.376 & 0.177 & 0.023 & 0.323 & 5.18 & 4.6 & 174.6 & 12.19 & 12.19 & W & $*$ & A \\
\hline CO98 & $1 / 31 / 2012$ & 2/7/2012 & 0.039 & 0.004 & 0.003 & 0.006 & 0.199 & 0.216 & 0.204 & 0.01 & 0.075 & 5.64 & 2.7 & 1084.7 & 33.53 & 33.53 & W & $*$ & A \\
\hline CO98 & $2 / 7 / 2012$ & $2 / 14 / 2012$ & 0.042 & 0.005 & 0.005 & 0.014 & 0.074 & 0.286 & 0.122 & 0.017 & 0.244 & 5.21 & 3.7 & 752.3 & 36.58 & 36.58 & W & $*$ & A \\
\hline CO98 & $2 / 14 / 2012$ & $2 / 21 / 2012$ & 0.106 & 0.011 & 0.008 & 0.022 & 0.109 & 0.649 & 0.231 & 0.032 & 0.254 & 5.11 & 4.9 & 274.8 & 18.29 & 18.29 & W & $*$ & A \\
\hline CO98 & $2 / 21 / 2012$ & $2 / 28 / 2012$ & 0.154 & 0.017 & 0.014 & 0.034 & 0.148 & 0.329 & 0.189 & 0.04 & 0.207 & 5.75 & 3.3 & 306.7 & 79.5 & 79.5 & W & $*$ & B \\
\hline $\mathrm{CO} 98$ & $2 / 28 / 2012$ & $3 / 6 / 2012$ & 0.284 & 0.031 & 0.011 & 0.086 & 0.048 & 0.375 & 0.122 & 0.069 & 0.242 & 6.06 & 3.3 & 248.4 & 34.04 & 34.04 & W & $*$ & A \\
\hline $\mathrm{CO} 98$ & $3 / 6 / 2012$ & $3 / 13 / 2012$ & -- & -- & -- & -- & -- & -- & -- & -- & -- & -- & -- & 0 & 0 & 0 & $\mathrm{D}$ & $*$ & A \\
\hline CO98 & $3 / 13 / 2012$ & $3 / 20 / 2012$ & 6.853 & 0.364 & 0.261 & 0.635 & 0.009 & 0.476 & 0.111 & 0.096 & 3.422 & 7.42 & 41.7 & 80 & 11.43 & 11.43 & W & $*$ & B \\
\hline CO98 & $3 / 20 / 2012$ & $3 / 27 / 2012$ & -- & -- & -- & -- & -- & -- & -- & -- & -- & -- & -- & 0 & 0 & 0 & $\mathrm{D}$ & $*$ & A \\
\hline CO98 & $3 / 27 / 2012$ & 4/3/2012 & 0.335 & 0.037 & 0.025 & 0.075 & 0.585 & 0.688 & 0.61 & 0.062 & 0.485 & 6.56 & 7.1 & 993.1 & 20.07 & 20.07 & W & $*$ & A \\
\hline CO98 & $4 / 3 / 2012$ & $4 / 10 / 2012$ & 0.123 & 0.027 & 0.007 & 0.024 & 0.088 & 0.254 & 0.126 & 0.061 & 0.079 & 5.63 & 3.3 & 51 & 0.51 & 0.51 & W & $*$ & A \\
\hline CO98 & $4 / 10 / 2012$ & $4 / 17 / 2012$ & 0.137 & 0.017 & 0.014 & 0.019 & 0.352 & 0.787 & 0.452 & 0.039 & 0.605 & 5.34 & 6.3 & 1600.4 & 36.07 & 36.07 & W & $*$ & A \\
\hline $\mathrm{CO} 98$ & $4 / 17 / 2012$ & $4 / 24 / 2012$ & 0.065 & 0.011 & 0.004 & 0.007 & 0.054 & 0.224 & 0.093 & 0.017 & 0.189 & 5.54 & 2.7 & 283.2 & 11.94 & 11.94 & W & $*$ & A \\
\hline
\end{tabular}


Table 1-1. Wet-deposition sample analysis data for colocated sites C089 and C098, water years 2010-14.-Continued

[Date on, start of weekly sample collection; Date off, end of weekly sample collection; $\mathrm{Ca}$, calcium; $\mathrm{Mg}$, magnesium; $\mathrm{K}$, potassium; $\mathrm{Na}$, sodium; $\mathrm{NH}_{4}$, ammonium; $\mathrm{NO}_{3}$, nitrate; $\mathrm{N}$, inorganic nitrogen; $\mathrm{Cl}$, chloride; $\mathrm{SO}_{4}$, sulfate; $\mathrm{pH}$, negative log of hydrogen-ion molarity; Cond, specific conductance in microSeimens per centimeter; Svol, sample volume in milliliters; RG ppt, rain gage precipitation depth in millimeters; Sub ppt, sample volume converted to depth substituted for missing weekly RG ppt. Lab types: W, sufficient volume for analysis; WD, dilution necessary to obtain volume for analysis; D, valid dry week; T, valid trace sample with insufficient volume for analysis. Inval codes: b, bulk sample (collector was open continuously); c, contaminated; d, debris; e, extended sampling period greater than 8 days; $h$, handling protocol problems; m, missing data; u, undefined; v, inadequate volume for analysis; z, site operation problems; *, no Inval code assigned. QR (Quality Rating) codes: A, highest quality rating;

B, valid with minor problems; C, invalid. Concentrations in milligrams per liter. Valid dry week samples have no chemical data and have QR code of A. --, no data]

\begin{tabular}{|c|c|c|c|c|c|c|c|c|c|c|c|c|c|c|c|c|c|c|c|}
\hline Site & Date on & Date off & $\mathrm{Ca}$ & $\mathbf{M g}$ & $\mathbf{K}$ & $\mathrm{Na}$ & $\mathrm{NH}_{4}$ & $\mathrm{NO}_{3}$ & $\mathbf{N}$ & CI & $\mathrm{SO}_{4}$ & $\mathrm{pH}$ & Cond & Svol & $\begin{array}{l}\text { RG } \\
\text { ppt }\end{array}$ & $\begin{array}{l}\text { Sub } \\
\text { ppt }\end{array}$ & $\begin{array}{l}\text { Lab } \\
\text { type }\end{array}$ & $\begin{array}{l}\text { Inval } \\
\text { codes }\end{array}$ & $\begin{array}{c}\mathrm{OR} \\
\text { code }\end{array}$ \\
\hline CO98 & $4 / 24 / 2012$ & $5 / 1 / 2012$ & -- & -- & -- & -- & -- & -- & -- & -- & -- & -- & -- & 664.8 & 15.24 & 15.24 & W & $\mathrm{c}$ & A \\
\hline CO98 & $5 / 1 / 2012$ & $5 / 8 / 2012$ & -- & -- & -- & -- & -- & -- & -- & -- & -- & -- & -- & 1384.6 & 25.91 & 25.91 & W & $\mathrm{c}$ & A \\
\hline CO98 & $5 / 8 / 2012$ & $5 / 15 / 2012$ & -- & -- & -- & -- & -- & -- & -- & -- & -- & -- & -- & 491.2 & 8.89 & 8.89 & W & $\mathrm{c}$ & A \\
\hline CO98 & $5 / 15 / 2012$ & $5 / 22 / 2012$ & 0.952 & 0.09 & 0.059 & 0.11 & 0.195 & 1.207 & 0.424 & 0.12 & 0.696 & 6.38 & 9 & 787.1 & 13.97 & 13.97 & W & $*$ & B \\
\hline CO98 & $5 / 22 / 2012$ & $5 / 29 / 2012$ & -- & -- & -- & -- & -- & -- & -- & -- & -- & -- & -- & 1248.1 & 27.43 & 27.43 & W & $\mathrm{c}$ & B \\
\hline CO98 & $5 / 29 / 2012$ & $6 / 5 / 2012$ & 0.532 & 0.06 & 0.074 & 0.041 & 0.189 & 0.764 & 0.32 & 0.085 & 0.469 & 6.06 & 6.1 & 648.3 & 8.89 & 8.89 & W & $*$ & B \\
\hline CO98 & $6 / 5 / 2012$ & $6 / 12 / 2012$ & -- & -- & -- & -- & -- & -- & -- & -- & -- & -- & -- & 0 & 0 & 0 & $\mathrm{D}$ & $*$ & A \\
\hline CO98 & $6 / 12 / 2012$ & $6 / 19 / 2012$ & -- & -- & -- & -- & -- & -- & -- & -- & -- & -- & -- & 40.8 & 0.51 & 0.51 & WD & $\mathrm{c}$ & B \\
\hline CO98 & $6 / 26 / 2012$ & $7 / 3 / 2012$ & -- & -- & -- & -- & -- & -- & -- & -- & -- & -- & -- & 552.9 & 8.38 & 8.38 & $\mathrm{~W}$ & $\mathrm{c}$ & B \\
\hline CO98 & 7/3/2012 & $7 / 10 / 2012$ & 0.129 & 0.013 & 0.026 & 0.012 & 0.369 & 1.016 & 0.517 & 0.03 & 0.397 & 5.48 & 5.9 & 2658.8 & 38.1 & 38.1 & W & $*$ & A \\
\hline CO98 & $7 / 10 / 2012$ & $7 / 17 / 2012$ & 0.262 & 0.028 & 0.06 & 0.022 & 0.76 & 2.333 & 1.118 & 0.09 & 1.021 & 5.02 & 13 & 574.1 & 7.11 & 7.11 & W & $*$ & A \\
\hline CO98 & $7 / 17 / 2012$ & $7 / 24 / 2012$ & 0.365 & 0.034 & 0.025 & 0.044 & 0.501 & 2.198 & 0.886 & 0.083 & 1.017 & 4.9 & 13 & 347.5 & 4.57 & 4.57 & W & $*$ & A \\
\hline $\mathrm{CO} 98$ & $7 / 24 / 2012$ & $7 / 31 / 2012$ & 0.11 & 0.013 & 0.018 & 0.016 & 0.26 & 0.876 & 0.4 & 0.033 & 0.435 & 5.18 & 6 & 3008.2 & 44.2 & 44.2 & W & $*$ & B \\
\hline CO98 & $7 / 31 / 2012$ & 8/7/2012 & 0.301 & 0.035 & 0.018 & 0.028 & 0.283 & 1.419 & 0.541 & 0.075 & 0.568 & 5.14 & 8.1 & 593.2 & 7.62 & 7.62 & W & $*$ & A \\
\hline CO98 & 8/7/2012 & $8 / 14 / 2012$ & 0.369 & 0.041 & 0.118 & 0.043 & 0.683 & 1.835 & 0.946 & 0.117 & 0.887 & 5.65 & 9.9 & 108.1 & 1.52 & 1.52 & W & $*$ & A \\
\hline $\mathrm{CO} 98$ & $8 / 14 / 2012$ & $8 / 21 / 2012$ & -- & -- & -- & -- & -- & -- & -- & -- & -- & -- & -- & 5.8 & 0 & 0.09 & $\mathrm{~T}$ & $*$ & A \\
\hline CO98 & $8 / 21 / 2012$ & $8 / 28 / 2012$ & 0.157 & 0.017 & 0.03 & & & 1.207 & & & 0.412 & 5.14 & 7.1 & 718.1 & 10.41 & 10.41 & W & $*$ & B \\
\hline CO98 & $8 / 28 / 2012$ & $9 / 4 / 2012$ & 0.231 & 0.035 & 0.046 & 0.029 & 0.358 & 1.483 & 0.613 & 0.064 & 0.652 & 5.08 & 8.8 & 1262.1 & 18.8 & 18.8 & W & $*$ & B \\
\hline CO98 & $9 / 4 / 2012$ & $9 / 11 / 2012$ & 0.498 & 0.06 & 0.035 & 0.052 & 0.485 & 1.648 & 0.75 & 0.101 & 1.142 & 5.66 & 9.4 & 414.6 & 5.59 & 5.59 & W & $*$ & A \\
\hline CO98 & $9 / 11 / 2012$ & $9 / 18 / 2012$ & 0.128 & 0.014 & 0.013 & 0.013 & 0.127 & 0.526 & 0.218 & 0.031 & 0.214 & 5.56 & 3.5 & 2025.5 & 30.23 & 30.23 & W & $*$ & B \\
\hline CO98 & $9 / 18 / 2012$ & $9 / 25 / 2012$ & 0.227 & 0.029 & 0.016 & 0.038 & 0.482 & 1.416 & 0.695 & 0.1 & 0.958 & 5.08 & 9.8 & 377.4 & 6.1 & 6.1 & W & $*$ & B \\
\hline CO98 & $9 / 25 / 2012$ & $10 / 2 / 2012$ & 0.026 & 0.003 & 0.004 & 0.003 & 0.145 & 0.336 & 0.189 & 0.011 & 0.191 & 5.32 & 3.3 & 2586.2 & 38.1 & 38.1 & W & $*$ & A \\
\hline CO98 & $10 / 2 / 2012$ & $10 / 9 / 2012$ & 0.818 & 0.085 & 0.064 & 0.198 & 0.267 & 1.489 & 0.544 & 0.129 & 0.826 & 6.5 & 9.2 & 87.6 & 1.78 & 1.78 & W & $*$ & A \\
\hline CO98 & $10 / 9 / 2012$ & $10 / 16 / 2012$ & 0.043 & 0.005 & 0.006 & 0.01 & 0.123 & 0.302 & 0.164 & 0.023 & 0.226 & 5.27 & 3.4 & 502.6 & 22.61 & 22.61 & W & $*$ & A \\
\hline $\mathrm{CO} 98$ & $10 / 16 / 2012$ & $10 / 23 / 2012$ & -- & -- & -- & -- & -- & -- & -- & -- & -- & -- & -- & 526.9 & 11.18 & 11.18 & W & $\mathrm{u}$ & $\mathrm{C}$ \\
\hline CO98 & $10 / 23 / 2012$ & $10 / 30 / 2012$ & 0.125 & 0.013 & 0.012 & 0.031 & 0.086 & 0.472 & 0.174 & 0.025 & 0.353 & 5.28 & 3.9 & 678.3 & 22.35 & 22.35 & W & $*$ & A \\
\hline CO98 & $10 / 30 / 2012$ & $11 / 6 / 2012$ & -- & -- & -- & -- & -- & -- & -- & -- & -- & -- & -- & 0.6 & 0 & 0 & $\mathrm{~T}$ & $*$ & A \\
\hline CO98 & $11 / 6 / 2012$ & $11 / 13 / 2012$ & 0.076 & 0.008 & 0.005 & 0.01 & 0.037 & 0.19 & 0.072 & 0.015 & 0.115 & 5.66 & 2.1 & 303.2 & 22.1 & 22.1 & $\mathrm{~W}$ & $*$ & A \\
\hline CO98 & $11 / 13 / 2012$ & $11 / 20 / 2012$ & 0.076 & 0.003 & 0.005 & 0.009 & 0.104 & 0.256 & 0.139 & 0.042 & 0.19 & 5.24 & 3.8 & 30.5 & 6.86 & 6.86 & WD & $*$ & B \\
\hline CO98 & $11 / 20 / 2012$ & $11 / 27 / 2012$ & -- & -- & -- & -- & -- & -- & -- & -- & -- & -- & -- & 0.4 & 0 & 0 & $\mathrm{~T}$ & $*$ & A \\
\hline CO98 & $11 / 27 / 2012$ & $12 / 11 / 2012$ & -- & -- & -- & -- & -- & -- & -- & -- & -- & -- & -- & 190.7 & 43.94 & 43.94 & W & e & $\mathrm{C}$ \\
\hline CO98 & $12 / 11 / 2012$ & $12 / 18 / 2012$ & 0.021 & 0.002 & 0.006 & 0.006 & 0.058 & 0.136 & 0.076 & 0.009 & 0.159 & 5.29 & 2.8 & 556.9 & 37.34 & 37.34 & W & $*$ & A \\
\hline CO98 & $12 / 18 / 2012$ & $12 / 25 / 2012$ & 0.02 & 0.002 & 0.002 & 0.007 & 0.09 & 0.41 & 0.163 & 0.016 & 0.063 & 5.43 & 2.9 & 963.5 & 28.45 & 28.45 & W & $*$ & A \\
\hline
\end{tabular}


[Date on, start of weekly sample collection; Date off, end of weekly sample collection; Ca, calcium; $\mathrm{Mg}$, magnesium; $\mathrm{K}$, potassium; $\mathrm{Na}$, sodium; $\mathrm{NH}_{4}$, ammonium; $\mathrm{NO}_{3}$, nitrate; $\mathrm{N}$, inorganic nitrogen; $\mathrm{Cl}$, chloride; $\mathrm{SO}_{4}$, sulfate; $\mathrm{pH}$, negative log of hydrogen-ion molarity; Cond, specific conductance in microSeimens per centimeter; Svol, sample volume in milliliters; RG ppt, rain gage precipitation depth in millimeters; Sub ppt, sample volume converted to depth substituted for missing weekly RG ppt. Lab types: W, sufficient volume for analysis; WD, dilution necessary to obtain volume for analysis; D, valid dry week; T, valid trace sample with insufficient volume for analysis. Inval codes: b, bulk sample (collector was open continuously); c, contaminated; d, debris; e, extended sampling period greater than 8 days; h, handling protocol problems; m, missing data; u, undefined; v, inadequate volume for analysis; z, site operation problems; *, no Inval code assigned. QR (Quality Rating) codes: A, highest quality rating; B, valid with minor problems; C, invalid. Concentrations in milligrams per liter. Valid dry week samples have no chemical data and have QR code of A. --, no data]

\begin{tabular}{|c|c|c|c|c|c|c|c|c|c|c|c|c|c|c|c|c|c|c|c|}
\hline Site & Date on & Date off & $\mathrm{Ca}$ & Mg & K & $\mathrm{Na}$ & $\mathrm{NH}_{4}$ & $\mathrm{NO}_{3}$ & $\mathbf{N}$ & Cl & $\mathrm{SO}_{4}$ & $\mathrm{pH}$ & Cond & Svol & $\begin{array}{l}\text { RG } \\
\text { ppt }\end{array}$ & $\begin{array}{l}\text { Sub } \\
\text { ppt }\end{array}$ & $\begin{array}{l}\text { Lab } \\
\text { type }\end{array}$ & $\begin{array}{l}\text { Inval } \\
\text { codes }\end{array}$ & $\begin{array}{c}\text { OR } \\
\text { code }\end{array}$ \\
\hline CO98 & $12 / 25 / 2012$ & $1 / 1 / 2013$ & 0.226 & 0.023 & 0.02 & 0.071 & 0.098 & 1.836 & 0.491 & 0.088 & 0.438 & 4.7 & 14 & 22.4 & 8.64 & 8.64 & WD & $*$ & B \\
\hline CO98 & $1 / 1 / 2013$ & $1 / 8 / 2013$ & -- & -- & -- & -- & -- & -- & -- & -- & -- & -- & -- & 0.3 & 0.76 & 0.76 & $\mathrm{~T}$ & $\mathrm{v}$ & $\mathrm{C}$ \\
\hline CO98 & $1 / 8 / 2013$ & $1 / 15 / 2013$ & 0.038 & 0.014 & 0.031 & 0.012 & 0.056 & 0.222 & 0.094 & 0.026 & 0.072 & 5.27 & 3.4 & 27.3 & 16 & 16 & WD & $*$ & B \\
\hline CO98 & $1 / 15 / 2013$ & $1 / 22 / 2013$ & -- & -- & -- & -- & -- & -- & -- & -- & -- & -- & -- & 0.2 & 0 & 0 & $\mathrm{~T}$ & $*$ & A \\
\hline CO98 & $1 / 22 / 2013$ & $1 / 29 / 2013$ & 0.014 & 0.004 & 0.002 & 0.007 & 0.056 & 0.324 & 0.117 & 0.013 & 0.052 & 5.32 & 2.7 & 227.2 & 17.78 & 17.78 & W & $*$ & A \\
\hline CO98 & $1 / 29 / 2013$ & $2 / 5 / 2013$ & 0.047 & 0.004 & 0.009 & 0.009 & 0.099 & 0.308 & 0.147 & 0.028 & 0.183 & 5.28 & 4.1 & 89.8 & 41.91 & 41.91 & W & $*$ & $\mathrm{~A}$ \\
\hline CO98 & $2 / 5 / 2013$ & $2 / 12 / 2013$ & 0.031 & 0.004 & 0.009 & 0.008 & 0.039 & 0.283 & 0.094 & 0.013 & 0.124 & 5.24 & 3.4 & 295.4 & 16.51 & 16.51 & W & $*$ & A \\
\hline CO98 & $2 / 12 / 2013$ & $2 / 19 / 2013$ & 0.078 & 0.01 & 0.009 & 0.02 & 0.132 & 0.505 & 0.217 & 0.034 & 0.196 & 5.37 & 4.2 & 165.2 & 20.57 & 20.57 & W & $*$ & A \\
\hline CO98 & $2 / 19 / 2013$ & $2 / 26 / 2013$ & 0.055 & 0.004 & 0.009 & 0.017 & 0.076 & 0.364 & 0.141 & 0.017 & 0.086 & 5.52 & 2.5 & 792.7 & 17.53 & 17.53 & W & $*$ & A \\
\hline CO98 & $2 / 26 / 2013$ & $3 / 5 / 2013$ & 0.034 & 0.004 & 0.009 & 0.009 & 0.097 & 0.225 & 0.126 & 0.025 & 0.262 & 5.21 & 4 & 401.8 & 23.37 & 23.37 & W & $*$ & A \\
\hline CO98 & $3 / 5 / 2013$ & $3 / 12 / 2013$ & 0.066 & 0.004 & 0.009 & 0.012 & 0.155 & 0.455 & 0.223 & 0.025 & 0.154 & 5.46 & 3.4 & 642.5 & 27.69 & 27.69 & W & $*$ & $\mathrm{~A}$ \\
\hline CO98 & $3 / 12 / 2013$ & $3 / 19 / 2013$ & 0.52 & 0.061 & 0.027 & 0.105 & 0.54 & 2.032 & 0.879 & 0.207 & 0.925 & 5.96 & 9.3 & 248.4 & 20.07 & 20.07 & W & $*$ & A \\
\hline CO98 & $3 / 19 / 2013$ & $3 / 26 / 2013$ & 0.137 & 0.015 & 0.011 & 0.065 & 0.154 & 0.351 & 0.199 & 0.057 & 0.272 & 5.96 & 3.1 & 1247 & 34.54 & 34.54 & W & $*$ & $\mathrm{~A}$ \\
\hline CO98 & $3 / 26 / 2013$ & $4 / 2 / 2013$ & 0.263 & 0.034 & 0.017 & 0.057 & 0.449 & 1.4 & 0.666 & 0.107 & 0.624 & 5.97 & 6.5 & 860.5 & 21.84 & 21.84 & W & $*$ & B \\
\hline CO98 & $4 / 2 / 2013$ & 4/9/2013 & 0.472 & 0.037 & 0.033 & 0.053 & 0.392 & 0.649 & 0.452 & 0.063 & 0.572 & 6.53 & 6.5 & 1928.2 & 45.21 & 45.21 & W & $*$ & A \\
\hline CO98 & 4/9/2013 & $4 / 23 / 2013$ & -- & -- & -- & -- & -- & -- & -- & -- & -- & -- & -- & -- & 214.38 & 1.66 & $\mathrm{~W}$ & $\mathrm{eu}$ & $\mathrm{C}$ \\
\hline CO98 & $4 / 23 / 2013$ & $4 / 30 / 2013$ & -- & -- & -- & -- & -- & -- & -- & -- & -- & -- & -- & -- & 17.78 & 0.54 & WD & $\mathrm{u}$ & $\mathrm{C}$ \\
\hline CO98 & $4 / 30 / 2013$ & $5 / 7 / 2013$ & -- & -- & -- & -- & -- & -- & -- & -- & -- & -- & -- & -- & 67.31 & 67.06 & $\mathrm{~W}$ & $\mathrm{u}$ & $\mathrm{C}$ \\
\hline CO98 & $5 / 7 / 2013$ & $5 / 14 / 2013$ & 0.121 & 0.013 & 0.007 & 0.014 & 0.607 & 0.668 & 0.623 & 0.024 & 0.443 & 6.31 & 5.5 & 3073.8 & 69.34 & 69.34 & W & $*$ & A \\
\hline CO98 & $5 / 14 / 2013$ & $5 / 21 / 2013$ & -- & -- & -- & -- & -- & -- & -- & -- & -- & -- & -- & 0.2 & -- & 0 & $\mathrm{~T}$ & $*$ & $\mathrm{C}$ \\
\hline CO98 & $5 / 21 / 2013$ & $6 / 4 / 2013$ & -- & -- & -- & -- & -- & -- & -- & -- & -- & -- & -- & -- & 20.83 & 0.01 & $\mathrm{~T}$ & $*$ & $\mathrm{C}$ \\
\hline CO98 & 6/4/2013 & $6 / 11 / 2013$ & 0.819 & 0.105 & 0.027 & 0.085 & 0.597 & 2.646 & 1.062 & 0.167 & 1.14 & 5.52 & 13.2 & 94.4 & 0.76 & 0.76 & W & $*$ & B \\
\hline CO98 & $6 / 11 / 2013$ & $6 / 18 / 2013$ & -- & -- & -- & -- & -- & -- & -- & -- & -- & -- & -- & -- & 2.54 & 2.54 & W & $\mathrm{c}$ & $\mathrm{C}$ \\
\hline CO98 & $6 / 18 / 2013$ & $6 / 25 / 2013$ & -- & -- & -- & -- & -- & -- & -- & -- & -- & -- & -- & 1.2 & 0 & 0 & $\mathrm{D}$ & $*$ & A \\
\hline CO98 & $6 / 25 / 2013$ & $7 / 2 / 2013$ & 0.277 & 0.038 & 0.089 & 0.026 & 0.675 & 1.115 & 0.777 & 0.073 & 0.515 & 6.34 & 7.7 & 617.9 & 9.14 & 9.14 & W & $*$ & A \\
\hline CO98 & $7 / 2 / 2013$ & 7/9/2013 & 0.093 & 0.013 & 0.035 & 0.017 & 0.282 & 0.574 & 0.349 & 0.047 & 0.27 & 5.47 & 4.6 & 2482.3 & 36.58 & 36.58 & W & $*$ & B \\
\hline CO98 & 7/9/2013 & $7 / 16 / 2013$ & 0.116 & 0.013 & 0.032 & 0.012 & 0.434 & 0.859 & 0.532 & 0.031 & 0.337 & 5.81 & 5.3 & 1467.6 & 21.59 & 21.59 & W & $*$ & $\mathrm{~B}$ \\
\hline CO98 & $7 / 16 / 2013$ & $7 / 23 / 2013$ & 0.108 & 0.014 & 0.017 & 0.01 & 0.254 & 1.123 & 0.451 & 0.036 & 0.474 & 4.91 & 8.2 & 650.4 & 9.91 & 9.91 & W & $*$ & A \\
\hline CO98 & $7 / 23 / 2013$ & $7 / 30 / 2013$ & 0.123 & 0.015 & 0.02 & 0.012 & 0.211 & 0.678 & 0.317 & 0.041 & 0.266 & 5.4 & 5.1 & 1771.9 & 25.91 & 25.91 & W & $*$ & B \\
\hline CO98 & $7 / 30 / 2013$ & 8/6/2013 & -- & -- & -- & -- & -- & -- & -- & -- & -- & -- & -- & -- & 3.81 & 3.56 & W & $\mathrm{c}$ & $\mathrm{C}$ \\
\hline CO98 & $8 / 6 / 2013$ & $8 / 13 / 2013$ & 0.173 & 0.02 & 0.028 & 0.017 & 0.637 & 1.231 & 0.774 & 0.062 & 0.7 & 5.81 & 7.6 & 746.6 & 10.67 & 10.67 & W & $*$ & $\mathrm{~B}$ \\
\hline CO98 & $8 / 13 / 2013$ & $8 / 20 / 2013$ & 0.104 & 0.024 & 0.172 & 0.058 & 1.148 & 0.721 & 1.056 & 0.089 & 0.6 & 6.51 & 9.8 & 474 & 6.35 & 6.35 & W & $*$ & B \\
\hline CO98 & $8 / 20 / 2013$ & $8 / 27 / 2013$ & 0.095 & 0.009 & 0.015 & 0.009 & 0.193 & 0.757 & 0.321 & 0.036 & 0.456 & 4.98 & 7.1 & 1181.1 & 18.03 & 18.03 & $\mathrm{~W}$ & $*$ & B \\
\hline
\end{tabular}


Table 1-1. Wet-deposition sample analysis data for colocated sites C089 and C098, water years 2010-14.-Continued

[Date on, start of weekly sample collection; Date off, end of weekly sample collection; $\mathrm{Ca}$, calcium; $\mathrm{Mg}$, magnesium; $\mathrm{K}$, potassium; $\mathrm{Na}$, sodium; $\mathrm{NH}_{4}$, ammonium; $\mathrm{NO}_{3}$, nitrate; $\mathrm{N}$, inorganic nitrogen; $\mathrm{Cl}$, chloride; $\mathrm{SO}_{4}$, sulfate; $\mathrm{pH}$, negative log of hydrogen-ion molarity; Cond, specific conductance in microSeimens per centimeter; Svol, sample volume in milliliters; RG ppt, rain gage precipitation depth in millimeters; Sub ppt, sample volume converted to depth substituted for missing weekly RG ppt. Lab types: W, sufficient volume for analysis; WD, dilution necessary to obtain volume for analysis; D, valid dry week; T, valid trace sample with insufficient volume for analysis. Inval codes: b, bulk sample (collector was open continuously); c, contaminated; d, debris; e, extended sampling period greater than 8 days; $h$, handling protocol problems; m, missing data; u, undefined; v, inadequate volume for analysis; z, site operation problems; *, no Inval code assigned. QR (Quality Rating) codes: A, highest quality rating;

B, valid with minor problems; C, invalid. Concentrations in milligrams per liter. Valid dry week samples have no chemical data and have QR code of A. --, no data]

\begin{tabular}{|c|c|c|c|c|c|c|c|c|c|c|c|c|c|c|c|c|c|c|c|}
\hline Site & Date on & Date off & Ca & Mg & K & $\mathrm{Na}$ & $\mathrm{NH}_{4}$ & $\mathrm{NO}_{3}$ & $\mathbf{N}$ & Cl & $\mathrm{SO}_{4}$ & $\mathrm{pH}$ & Cond & Svol & $\begin{array}{l}\text { RG } \\
\text { ppt }\end{array}$ & $\begin{array}{l}\text { Sub } \\
\text { ppt }\end{array}$ & $\begin{array}{l}\text { Lab } \\
\text { type }\end{array}$ & $\begin{array}{l}\text { Inval } \\
\text { codes }\end{array}$ & $\begin{array}{c}\text { OR } \\
\text { code }\end{array}$ \\
\hline CO98 & $8 / 27 / 2013$ & $9 / 3 / 2013$ & 0.112 & 0.011 & 0.013 & 0.013 & 0.287 & 0.91 & 0.429 & 0.032 & 0.522 & 5.12 & 7.2 & 1822.7 & 26.42 & 26.42 & W & $*$ & B \\
\hline CO98 & $9 / 3 / 2013$ & $9 / 10 / 2013$ & 0.203 & 0.017 & 0.018 & 0.013 & 0.448 & 1.258 & 0.633 & 0.045 & 0.512 & 5.52 & 6.8 & 1984.4 & 28.96 & 28.96 & W & $*$ & B \\
\hline CO98 & $9 / 10 / 2013$ & $9 / 19 / 2013$ & -- & -- & -- & -- & -- & -- & -- & -- & -- & -- & -- & -- & 156.21 & 156.21 & W & e & $\mathrm{C}$ \\
\hline CO98 & $9 / 19 / 2013$ & $9 / 24 / 2013$ & 0.033 & 0.004 & 0.012 & 0.01 & 0.063 & 0.325 & 0.122 & 0.026 & 0.165 & 5.36 & 3.5 & 1630.9 & 31.5 & 31.5 & W & $*$ & B \\
\hline CO98 & $9 / 24 / 2013$ & $9 / 30 / 2013$ & 0.126 & 0.01 & 0.016 & 0.013 & 0.043 & 0.165 & 0.071 & 0.023 & 0.15 & 5.71 & 2.3 & 493.6 & 23.11 & 23.11 & W & $*$ & B \\
\hline CO98 & $9 / 30 / 2013$ & $10 / 15 / 2013$ & -- & -- & -- & -- & -- & -- & -- & -- & -- & -- & -- & 737.1 & 51.56 & 51.56 & W & $\mathrm{e}$ & $\mathrm{C}$ \\
\hline CO98 & $10 / 15 / 2013$ & $10 / 22 / 2013$ & 0.03 & 0.004 & 0.005 & 0.003 & 0.2 & 0.354 & 0.236 & 0.014 & 0.369 & 5.21 & 4.8 & 608.6 & 18.29 & 18.29 & W & $*$ & A \\
\hline CO98 & $10 / 22 / 2013$ & $10 / 29 / 2013$ & -- & -- & -- & -- & -- & -- & -- & -- & -- & -- & -- & 0.2 & 0 & 0 & $\mathrm{~T}$ & $*$ & A \\
\hline CO98 & $10 / 29 / 2013$ & $11 / 5 / 2013$ & 0.107 & 0.016 & 0.062 & 0.03 & 0.059 & 0.586 & 0.178 & 0.043 & 0.307 & 5.18 & 5.1 & 412.6 & 45.21 & 45.21 & $\mathrm{~W}$ & $*$ & B \\
\hline CO98 & $11 / 5 / 2013$ & $11 / 12 / 2013$ & & & & & & & & & & & & 0.3 & 1.52 & 1.52 & $\mathrm{~T}$ & $\mathrm{v}$ & $\mathrm{C}$ \\
\hline CO98 & $11 / 12 / 2013$ & $11 / 19 / 2013$ & 0.08 & 0.036 & 0.016 & 0.02 & 0.088 & 0.302 & 0.137 & 0.024 & 0.206 & 5.39 & 4.6 & 30.8 & & 42.67 & WD & $*$ & B \\
\hline CO98 & $11 / 19 / 2013$ & $11 / 26 / 2013$ & 0.014 & 0.004 & 0.003 & 0.003 & 0.061 & 0.194 & 0.091 & 0.006 & 0.051 & 5.35 & 2.7 & 974.1 & 24.13 & 24.13 & $\mathrm{~W}$ & $*$ & A \\
\hline CO98 & $11 / 26 / 2013$ & $12 / 11 / 2013$ & -- & -- & -- & -- & -- & -- & -- & -- & -- & -- & -- & 1196.8 & 63.25 & 63.25 & W & $\mathrm{e}$ & $\mathrm{C}$ \\
\hline CO98 & $12 / 11 / 2013$ & $12 / 17 / 2013$ & -- & -- & -- & -- & -- & -- & -- & -- & -- & -- & -- & 0 & 2.03 & 2.03 & $\mathrm{D}$ & $\mathrm{v}$ & $\mathrm{C}$ \\
\hline CO98 & $12 / 17 / 2013$ & $12 / 24 / 2013$ & 0.151 & 0.021 & 0.019 & 0.015 & 0.058 & 0.727 & 0.209 & 0.04 & 0.237 & 5.2 & 4.9 & 59.8 & 32.77 & 32.77 & WD & $*$ & B \\
\hline CO98 & $12 / 24 / 2013$ & $12 / 31 / 2013$ & 0.032 & 0.002 & 0.002 & 0.008 & 0.049 & 0.43 & 0.135 & 0.013 & 0.067 & 5.2 & 3.5 & 418.8 & 13.72 & 13.72 & $\mathrm{~W}$ & $*$ & B \\
\hline CO98 & $12 / 31 / 2013$ & $1 / 7 / 2014$ & 0.029 & 0.004 & 0.005 & 0.01 & 0.067 & 0.265 & 0.112 & 0.026 & 0.165 & 5.31 & 3.5 & 828.3 & 57.66 & 57.66 & W & $*$ & B \\
\hline CO98 & $1 / 7 / 2014$ & $1 / 14 / 2014$ & 0.093 & 0.009 & 0.009 & 0.034 & 0.143 & 0.261 & 0.17 & 0.029 & 0.291 & 5.58 & 3.7 & 182.7 & 66.29 & 66.29 & W & $*$ & $\mathrm{C}$ \\
\hline CO98 & $1 / 14 / 2014$ & $1 / 21 / 2014$ & -- & -- & -- & -- & -- & -- & -- & -- & -- & 5.07 & 9.8 & 14.9 & 3.56 & 3.56 & $\mathrm{~T}$ & $*$ & $\mathrm{C}$ \\
\hline CO98 & $1 / 21 / 2014$ & $1 / 28 / 2014$ & 0.039 & 0.008 & 0.004 & 0.018 & 0.141 & 0.586 & 0.242 & 0.046 & & 5.22 & 5 & 556.4 & & 28.96 & W & $*$ & A \\
\hline CO98 & $1 / 28 / 2014$ & $2 / 4 / 2014$ & 0.009 & 0.001 & 0.001 & 0.002 & 0.045 & 0.179 & 0.075 & 0.004 & 0.04 & 5.38 & 2.4 & 1386.2 & 58.93 & 58.93 & W & $*$ & A \\
\hline CO98 & $2 / 4 / 2014$ & $2 / 11 / 2014$ & 0.032 & 0.004 & 0.005 & 0.012 & 0.063 & 0.296 & 0.116 & 0.017 & 0.205 & 5.11 & 3.9 & 998.4 & 0 & 14.71 & $\mathrm{~W}$ & $*$ & B \\
\hline CO98 & $2 / 11 / 2014$ & $2 / 18 / 2014$ & 0.808 & 0.106 & 0.089 & 0.278 & 0.636 & 2.865 & 1.142 & 0.179 & & 5.73 & 15.5 & 36.5 & & 84.58 & WD & $*$ & $\mathrm{C}$ \\
\hline CO98 & $2 / 18 / 2014$ & $2 / 25 / 2014$ & 0.792 & 0.087 & 0.04 & 0.189 & 0.298 & 1.172 & 0.497 & 0.126 & 0.892 & 6.29 & 9.4 & 122.9 & 48.77 & 48.77 & $\mathrm{~W}$ & $*$ & $\mathrm{C}$ \\
\hline CO98 & $2 / 25 / 2014$ & $3 / 4 / 2014$ & 0.246 & 0.031 & 0.022 & 0.05 & 0.34 & 0.953 & 0.48 & 0.078 & 0.629 & 5.5 & 6.6 & 189 & 0 & 14.71 & W & $*$ & B \\
\hline CO98 & $3 / 4 / 2014$ & $3 / 11 / 2014$ & 0.057 & 0.007 & 0.006 & 0.016 & 0.151 & 0.342 & 0.195 & 0.015 & 0.151 & 5.53 & 2.9 & 1404.2 & 39.62 & 39.62 & W & $*$ & B \\
\hline CO98 & $3 / 11 / 2014$ & $3 / 18 / 2014$ & 2.164 & 0.222 & 0.097 & & & 1.046 & 0.552 & 0.397 & & 7 & 21.9 & & & 17.53 & W & $*$ & $\mathrm{C}$ \\
\hline CO98 & $3 / 18 / 2014$ & $3 / 25 / 2014$ & 0.435 & 0.056 & 0.035 & 0.094 & 0.177 & 1.141 & 0.395 & 0.089 & 0.414 & 5.88 & 5.7 & 704.7 & 23.11 & 23.11 & W & $*$ & B \\
\hline CO98 & $3 / 25 / 2014$ & $4 / 1 / 2014$ & 1.898 & 0.122 & 0.075 & 0.066 & 0.367 & 1.315 & 0.583 & 0.105 & 0.865 & 6.95 & 15.2 & 315.1 & 61.47 & 61.47 & W & $*$ & $\mathrm{C}$ \\
\hline CO98 & $4 / 1 / 2014$ & 4/8/2014 & 0.16 & 0.014 & 0.008 & 0.018 & 0.115 & 0.283 & 0.153 & 0.018 & 0.24 & 5.69 & 3 & 985.6 & 32.26 & 32.26 & W & $*$ & B \\
\hline CO98 & $4 / 8 / 2014$ & $4 / 15 / 2014$ & 0.134 & 0.017 & 0.021 & 0.025 & 0.184 & 0.312 & 0.214 & 0.02 & 0.165 & 5.96 & 2.9 & 1388.8 & 44.96 & 44.96 & W & $*$ & B \\
\hline CO98 & $4 / 15 / 2014$ & $4 / 22 / 2014$ & -- & -- & -- & -- & -- & -- & -- & -- & -- & -- & -- & 12.5 & 4.57 & 4.57 & $\mathrm{~T}$ & $*$ & $\mathrm{C}$ \\
\hline CO98 & $4 / 22 / 2014$ & $4 / 29 / 2014$ & 0.548 & 0.055 & 0.034 & 0.087 & 0.125 & 0.358 & 0.178 & 0.059 & 0.354 & 6.47 & 5.2 & 360.4 & 28.96 & 28.96 & W & $*$ & B \\
\hline
\end{tabular}


[Date on, start of weekly sample collection; Date off, end of weekly sample collection; Ca, calcium; $\mathrm{Mg}$, magnesium; $\mathrm{K}$, potassium; $\mathrm{Na}$, sodium; $\mathrm{NH}_{4}$, ammonium; $\mathrm{NO}_{3}$, nitrate; $\mathrm{N}$, inorganic nitrogen; $\mathrm{Cl}$, chloride; $\mathrm{SO}_{4}$, sulfate; $\mathrm{pH}$, negative log of hydrogen-ion molarity; Cond, specific conductance in microSeimens per centimeter; Svol, sample volume in milliliters; RG ppt, rain gage precipitation depth in millimeters; Sub ppt, sample volume converted to depth substituted for missing weekly RG ppt. Lab types: W, sufficient volume for analysis; WD, dilution necessary to obtain volume for analysis; D, valid dry week; T, valid trace sample with insufficient volume for analysis. Inval codes: b, bulk sample (collector was open continuously); c, contaminated; d, debris; e, extended sampling period greater than 8 days; h, handling protocol problems; m, missing data; u, undefined; v, inadequate volume for analysis; z, site operation problems; *, no Inval code assigned. QR (Quality Rating) codes: A, highest quality rating; B, valid with minor problems; C, invalid. Concentrations in milligrams per liter. Valid dry week samples have no chemical data and have QR code of A. --, no data]

\begin{tabular}{|c|c|c|c|c|c|c|c|c|c|c|c|c|c|c|c|c|c|c|c|}
\hline Site & Date on & Date off & $\mathrm{Ca}$ & Mg & K & $\mathrm{Na}$ & $\mathrm{NH}_{4}$ & $\mathrm{NO}_{3}$ & $\mathbf{N}$ & $\mathrm{Cl}$ & $\mathrm{SO}_{4}$ & pH & Cond & Svol & $\begin{array}{l}\text { RG } \\
\text { ppt }\end{array}$ & $\begin{array}{l}\text { Sub } \\
\text { ppt }\end{array}$ & $\begin{array}{l}\text { Lab } \\
\text { type }\end{array}$ & $\begin{array}{l}\text { Inval } \\
\text { codes }\end{array}$ & $\begin{array}{c}\text { OR } \\
\text { code }\end{array}$ \\
\hline CO98 & $4 / 29 / 2014$ & $5 / 6 / 2014$ & -- & -- & -- & -- & -- & -- & -- & -- & -- & -- & -- & 0.6 & 4.06 & 4.06 & $\mathrm{~T}$ & $*$ & $\mathrm{C}$ \\
\hline CO98 & $5 / 6 / 2014$ & $5 / 13 / 2014$ & 0.181 & 0.021 & 0.036 & 0.052 & 0.14 & 0.338 & 0.185 & 0.069 & 0.229 & 5.96 & 3.1 & 2194.8 & 71.63 & 71.63 & W & $*$ & A \\
\hline CO98 & $5 / 13 / 2014$ & $5 / 20 / 2014$ & 0.518 & 0.069 & 0.034 & 0.12 & 0.439 & 1.437 & 0.666 & 0.187 & 0.872 & 6.01 & 8.3 & 442.6 & 14.99 & 14.99 & W & $*$ & B \\
\hline $\mathrm{CO} 98$ & $5 / 20 / 2014$ & $5 / 27 / 2014$ & 0.052 & 0.006 & 0.008 & 0.01 & 0.419 & 0.677 & 0.479 & 0.023 & 0.215 & 6.06 & 4.1 & 2630.2 & 39.12 & 39.12 & W & $*$ & A \\
\hline CO98 & $5 / 27 / 2014$ & $6 / 3 / 2014$ & 0.623 & 0.072 & 0.069 & 0.073 & 0.694 & 1.886 & 0.966 & 0.173 & 0.927 & 6.3 & 11.1 & -- & 14.73 & 14.73 & W & $*$ & $\mathrm{C}$ \\
\hline CO98 & $6 / 3 / 2014$ & $6 / 10 / 2014$ & 0.828 & 0.114 & 0.084 & 0.134 & 0.647 & 1.911 & 0.935 & 0.2 & 1.526 & 6.14 & 12.8 & 279.4 & 6.35 & 6.35 & W & $*$ & $\mathrm{C}$ \\
\hline CO98 & $6 / 10 / 2014$ & $6 / 17 / 2014$ & -- & -- & -- & -- & -- & -- & -- & -- & -- & -- & -- & 0.2 & 5.08 & 5.08 & $\mathrm{~T}$ & $*$ & $\mathrm{C}$ \\
\hline CO98 & $6 / 17 / 2014$ & $6 / 24 / 2014$ & -- & -- & -- & -- & -- & -- & -- & -- & -- & 7.45 & 229.4 & 16.8 & 3.56 & 3.56 & $\mathrm{~T}$ & $*$ & $\mathrm{C}$ \\
\hline CO98 & $6 / 24 / 2014$ & $7 / 1 / 2014$ & -- & -- & -- & -- & -- & -- & -- & -- & -- & -- & -- & 0.2 & 4.57 & 4.57 & $\mathrm{~T}$ & $*$ & $\mathrm{C}$ \\
\hline CO98 & $7 / 1 / 2014$ & $7 / 8 / 2014$ & 0.435 & 0.064 & 0.092 & 0.092 & 0.527 & 1.423 & 0.731 & 0.175 & 0.736 & 6 & 8.7 & 281.8 & 6.35 & 6.35 & W & $*$ & $\mathrm{C}$ \\
\hline CO98 & $7 / 8 / 2014$ & $7 / 15 / 2014$ & 0.125 & 0.018 & 0.033 & 0.019 & 0.306 & 0.848 & 0.43 & 0.048 & 0.281 & 5.46 & 5.2 & 624.6 & 8.89 & 8.89 & W & $*$ & B \\
\hline CO98 & $7 / 15 / 2014$ & $7 / 22 / 2014$ & 0.445 & 0.066 & 0.107 & 0.089 & 0.619 & 1.185 & 0.749 & 0.146 & 0.697 & 6.21 & 9.2 & 965 & 13.97 & 13.97 & W & $*$ & $\mathrm{C}$ \\
\hline CO98 & $7 / 22 / 2014$ & $7 / 29 / 2014$ & 0.291 & 0.025 & 0.05 & 0.018 & 0.419 & 0.861 & 0.52 & 0.049 & 0.393 & 6.02 & 6 & 2087.5 & 29.97 & 29.97 & W & $*$ & B \\
\hline CO98 & $7 / 29 / 2014$ & $8 / 5 / 2014$ & 0.017 & 0.002 & 0.01 & 0.005 & 0.044 & 0.256 & 0.092 & 0.015 & 0.086 & 5.23 & 3.1 & 4897.6 & 74.17 & 74.17 & W & $*$ & B \\
\hline CO98 & $8 / 5 / 2014$ & $8 / 12 / 2014$ & 0.123 & 0.018 & 0.029 & 0.015 & 0.351 & 0.907 & 0.478 & 0.054 & 0.495 & 5.03 & 7.6 & 1021.7 & 14.22 & 14.22 & W & $*$ & B \\
\hline CO98 & $8 / 12 / 2014$ & $8 / 19 / 2014$ & 0.087 & 0.011 & 0.014 & 0.017 & 0.246 & 0.684 & 0.346 & 0.044 & 0.304 & 5.39 & 4.9 & 846.5 & 11.68 & 11.68 & W & $*$ & B \\
\hline CO98 & $8 / 19 / 2014$ & $8 / 26 / 2014$ & 0.083 & 0.01 & 0.018 & 0.02 & 0.165 & 0.612 & 0.267 & 0.039 & 0.262 & 5.26 & 4.6 & 1336.4 & 20.83 & 20.83 & W & $*$ & B \\
\hline CO98 & $8 / 26 / 2014$ & $9 / 2 / 2014$ & 0.15 & 0.018 & 0.071 & 0.027 & 0.265 & 0.925 & 0.415 & 0.073 & 0.343 & 5.4 & 5.7 & 1350.5 & 22.1 & 22.1 & W & $*$ & B \\
\hline CO98 & $9 / 2 / 2014$ & $9 / 9 / 2014$ & 0.138 & 0.019 & 0.023 & 0.044 & 0.265 & 0.862 & 0.401 & 0.078 & 0.315 & 5.43 & 5 & 1061.5 & 15.49 & 15.49 & W & $*$ & B \\
\hline $\mathrm{CO} 98$ & 9/9/2014 & $9 / 16 / 2014$ & 0.048 & 0.007 & 0.024 & 0.015 & 0.066 & 0.249 & 0.108 & 0.023 & 0.11 & 5.43 & 3 & 1674.6 & 27.43 & 27.43 & W & $*$ & B \\
\hline CO98 & $9 / 16 / 2014$ & $9 / 23 / 2014$ & 0.033 & 0.005 & 0.01 & 0.014 & 0.115 & 0.33 & 0.164 & 0.024 & 0.182 & 5.35 & 3.4 & 1773.8 & 28.7 & 28.7 & W & $*$ & B \\
\hline CO98 & $9 / 23 / 2014$ & $9 / 30 / 2014$ & 0.05 & 0.006 & 0.006 & 0.009 & 0.134 & 0.289 & 0.17 & 0.015 & 0.226 & 5.49 & 3.1 & 1737.1 & 32.51 & 32.51 & W & $*$ & $\mathrm{~B}$ \\
\hline
\end{tabular}


